
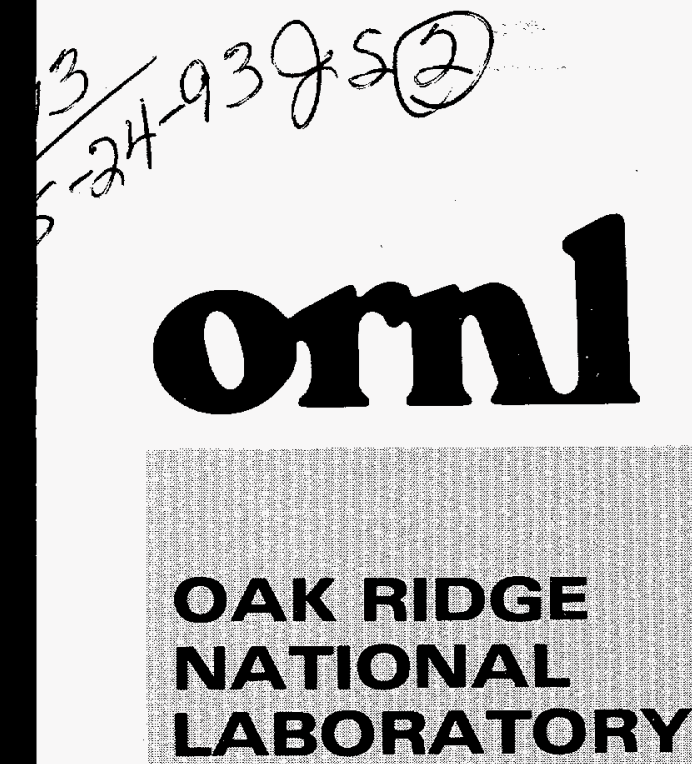

MARTIN MAGUETRA

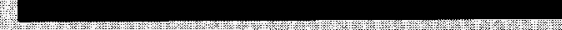

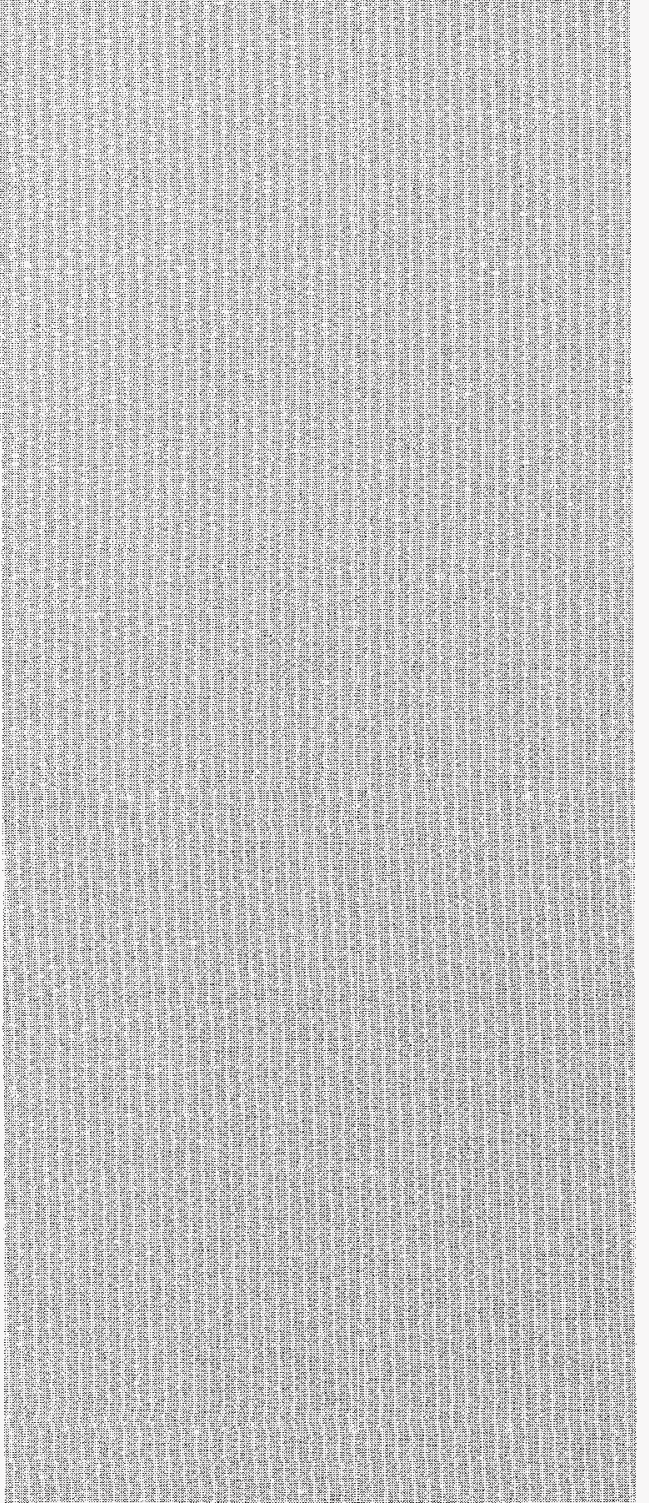

MANAGEO BY

MARTIN MARIETTA ENERGY SYSTEMS, INC. FOR THE UNITED STATES

DEPARTMENT OF ENERGY

\title{
Measurements for the JASPER Program Special Materials Experiment
}

\author{
F. J. Muckenthaler \\ R. R. Spencer \\ H. T. Hunter \\ J. L. Hull \\ A. Shono
}

\section{MASTER}


This report has been reproduced directly from the best available copy.

Available to DOE and DOE contractors from the Office of Scientific and Technical Information, P.O. Box 62, Oak Ridge, TN 37831; prices available from (615) 576-8401, FTS 626-8401.

This report was prepared as an account of work sponsored by an agency of the United States Government. Neither the United States Government nor any agency thereof, nor any of their employees, makes any warranty, express or implied, or assumes any legal liability or responsibility for the accuracy, completeness, or usefulness of any information, apparatus, product, or process disclosed, or represents that its use would not infringe privately owned rights. Reference herein to any specific commercial product, process, or service by trade name, trademark, manufacturer, or otherwise, does not necessarily constitute or imply its endorsement, recommendation, or favoring by the United States Government or any agency thereof. The views and opinions of authors expressed herein do not necessarily state or reflect those of the United States Government or any agency thereof. 
ORNL/TM-12277

Distribution Category

UC-534'

Engineering Physics and Mathematics Division

\title{
MEASUREMENTS FOR THE JASPER PROGRAM SPECIAL MATERIALS EXPERIMENT
}

\author{
F. J. Muckenthaler \\ R. R. Spencer \\ H. T. Hunter \\ J. L. Hull" \\ A. Shono**
}

Date Published: February 1993

Oak Ridge National Laboratory

Oak Ridge, Tennessee 37831-6363

Prepared for the

U.S. DOE Office of

Liquid Metal Converter Reactor

"Research Reactors Division

**Japan Power Reactor and Nuclear Fuel Development Corporation

DISCLAIMER

\begin{abstract}
This report was prepared as an account of work sponsored by an agency of the United States Government. Neither the United States Government nor any agency thereof, nor any of their employees, makes any warranty, express or implied, or assumes any legal liability or responsibility for the accuracy, completeness, or usefulness of any information, apparatus, product, or process disclosed, or represents that its use would not infringe privately owned rights. Reference herein to any specific commercial product, process, or service by trade name, trademark, manufacturer, or otherwise does not necessarily constitute or imply its endorsement, recommendation, or favoring by the United States Government or any agency thereof. The views and opinions of authors expressed herein do not necessarily state or reflect those of the United States Government or any agency thereof.
\end{abstract}

Prepared by the

OAK RIDGE NATIONAL LABORATORY

Oak Ridge, Tennessee 37831

managed by

MARTIN MARIETTA ENERGY SYSTEMS, INC.

for the

U.S. Department of Energy

under contract DE-AC05-84OR21400 


\section{DISCLAIMIER}

Portions of this document may be illegible in electronic image products. Images are produced from the best available original document. 


\section{TABLE OF CONTENTS}

$\underline{\text { Page }}$

List of Tables $\ldots \ldots \ldots \ldots \ldots \ldots \ldots \ldots \ldots \ldots \ldots \ldots \ldots \ldots \ldots \ldots$

List of Figures $\ldots \ldots \ldots \ldots \ldots \ldots \ldots \ldots \ldots \ldots \ldots \ldots \ldots \ldots \ldots \ldots \ldots$

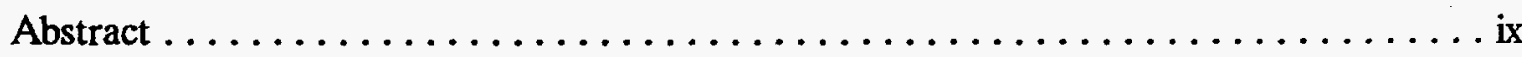

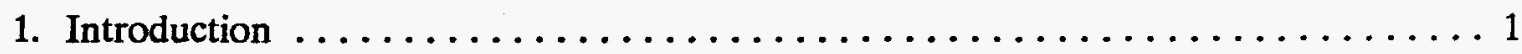

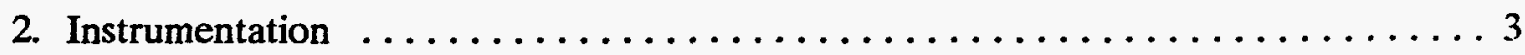

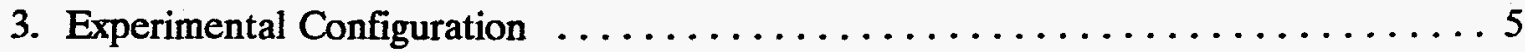

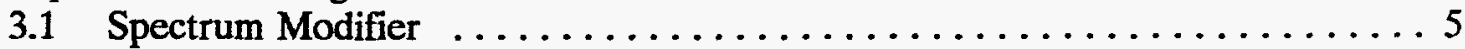

3.2 Aluminum Slab . . . . . . . . . . . . . . . . . . . . . 6

3.3 Stainless Steel Slabs $\ldots \ldots \ldots \ldots \ldots \ldots \ldots \ldots \ldots \ldots \ldots \ldots \ldots \ldots \ldots$

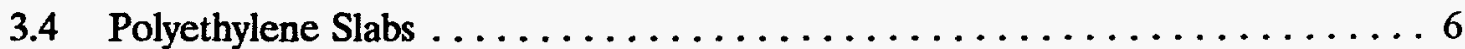

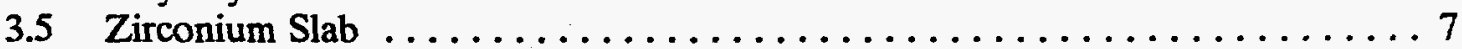

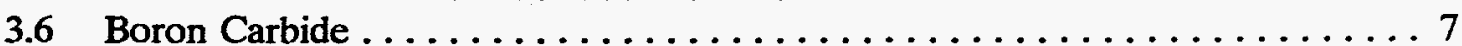

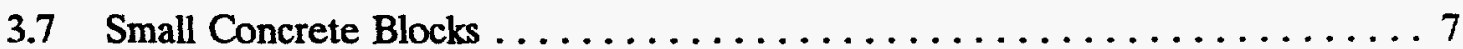

3.8 Lead Slabs . . . . . . . . . . . . . . . . . . . . . . . . 8

3.9 Background Shield $\ldots \ldots \ldots \ldots \ldots \ldots \ldots \ldots \ldots \ldots \ldots \ldots$

4. Measurements $\ldots \ldots \ldots \ldots \ldots \ldots \ldots \ldots \ldots \ldots \ldots \ldots \ldots \ldots \ldots$

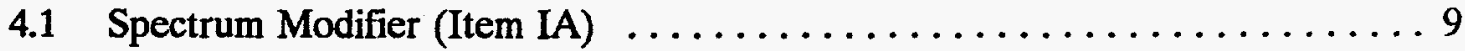

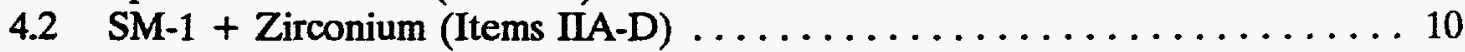

$4.3 \mathrm{SM}-1+$ Polyethylene (Items IIIA-C) $\ldots \ldots \ldots \ldots \ldots \ldots \ldots \ldots \ldots \ldots \ldots$

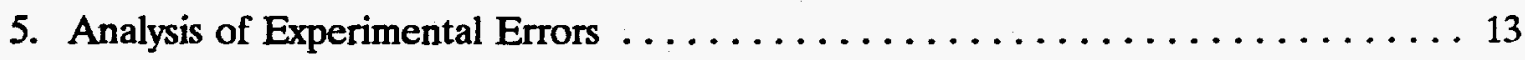

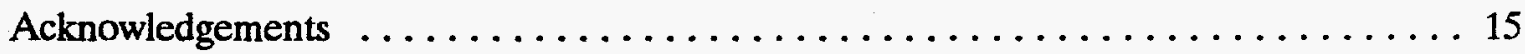

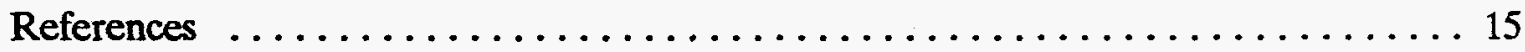

Appendix A. Experimental Program Plan for the JASPER Special

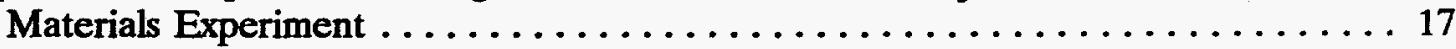

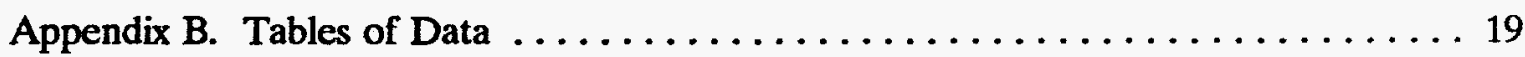

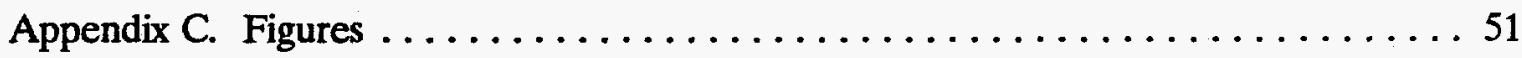





\section{LIST OF TABLES}

$\underline{\text { Page }}$

Table 1. Analysis of iron slabs $(\rho=7.86 \mathrm{~g} / \mathrm{cc})$ used in spectrum modifier $\ldots \ldots 21$

Table 2. Analysis of 6061 aluminum $(\rho=2.70 \mathrm{~g} / \mathrm{cc}) \quad \ldots \ldots \ldots \ldots \ldots \ldots$

Table 3. Composition of boral slabs used in spectrum modifier $\ldots \ldots \ldots 22$

Table 4. Composition of $\mathrm{UO}_{2}$ radial blanket $\ldots \ldots \ldots \ldots \ldots \ldots \ldots$

Table 5. Analysis of aluminum used in $\mathrm{UO}_{2}$ radial blanket cladding

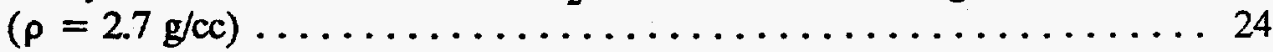

Table 6. Composition of lithiated-paraffin bricks $(\rho=1.15 \mathrm{~g} / \mathrm{cc}) \ldots \ldots \ldots$

Table 7. Analysis of $61-\mathrm{cm} \times 61-\mathrm{cm} \times 30.5-\mathrm{cm}(\rho=2.40 \mathrm{~g} / \mathrm{cc})$ concrete blocks used to surround configuration ............... 25

Table 8. Analysis of type 304 stainless steel $(\rho=7.92 \mathrm{~g} / \mathrm{cc}) \ldots \ldots \ldots \ldots$

Table 9. Analysis of polyethylene slabs $(\rho=0.955 \mathrm{~g} / \mathrm{cc}) \ldots \ldots \ldots \ldots \ldots$

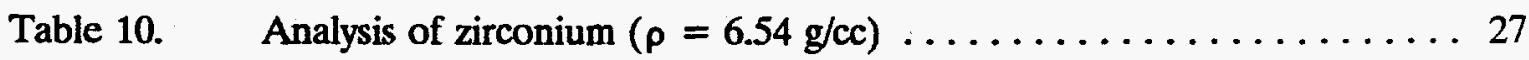

Table 11. Analysis of boron carbide used in shield mockups $\ldots \ldots \ldots \ldots \ldots$

Table 12. Composition of the small concrete blocks on each side of the mockup beyond spectrum modifier $(\rho=2.39 \mathrm{~g} / \mathrm{cc}) \ldots \ldots \ldots 29$

Table 13. Analysis of lead slabs $(\rho=11.35 \mathrm{~g} / \mathrm{cc}) \ldots \ldots \ldots \ldots \ldots \ldots$

Table 14. Spectrum of high-energy neutrons $(>0.8 \mathrm{MeV})$ on centerline at $25 \mathrm{~cm}$ behind the lead slabs (Item IA): Run 7931.A . . . . . . . 31

Table 15. Neutron spectrum ( $50 \mathrm{keV}$ to $1.4 \mathrm{MeV}$ ) on centerline at $25 \mathrm{~cm}$ behind the lead slabs (Item IA) Runs 1602.C, 1602.B, 1602.A . . . . . 32

Table 16. Bonner ball measurements on centerline at NE 213 location (Items IA, IIB, C, D, IIIA, B, C) $\ldots \ldots \ldots \ldots \ldots \ldots \ldots \ldots \ldots$

Table 17. Bonner ball measurements on centerline at $30 \mathrm{~cm}$ behind mockups (Items IA, IIA-D, IIIA-C) $\ldots \ldots \ldots \ldots \ldots \ldots \ldots \ldots$

Table 18. Bonner ball measurements on centerline at $150 \mathrm{~cm}$ behind mockups (Items IA, IIA-D, IIIA-C) $\ldots \ldots \ldots \ldots \ldots \ldots \ldots \ldots$ 
Table 19. Spectrum of high-energy neutrons $(>0.8 \mathrm{MeV})$ on centerline at $25 \mathrm{~cm}$ behind the lead slabs (Item IIB): Run $7932 \ldots \ldots \ldots \ldots \ldots 36$

Table 20. Neutron spectrum ( $50 \mathrm{keV}$ to $1.4 \mathrm{MeV})$ on centerline at $25 \mathrm{~cm}$ behind the lead slabs (Item IIB) Runs 1603.C, 1603.B, 1603.A ..... 37

Table 21. 3-inch Bonner ball traverses through the horizontal midplane at $30 \mathrm{~cm}$ behind a series of configurations (Items IIB-D, IIIB-C) . . . . 38

Table 22. 5-inch Bonner ball traverses through the horizontal midplane at $30 \mathrm{~cm}$ behind a series of configurations (Items IIB-D, IIIB-C) . . . . 39

Table 23. 8-inch Bonner ball traverses through the horizontal midplane at $30 \mathrm{~cm}$ behind a series of configurations (Items IIB-D, IIIB-C) . . . . 40

Table 24. Spectrum of high-energy neutrons $(>0.8 \mathrm{MeV})$ on centerline at $25 \mathrm{~cm}$ behind the lead slabs (Item IIC): Run $7933 \ldots \ldots \ldots \ldots .41$

Table 25. Neutron spectrum ( $50 \mathrm{keV}$ to $1.4 \mathrm{MeV}$ ) on centerline at $25 \mathrm{~cm}$ behind the lead slabs (Item IIC) Runs 1604.C, 1604.B, 1604.A . . . . . 42

Table 26. Spectrum of high-energy neutrons $(>0.8 \mathrm{MeV})$ on centerline at $25 \mathrm{~cm}$ behind the lead slabs (Item IID): Run $7934 \ldots \ldots \ldots \ldots \ldots 43$

Table 27. Neutron spectrum ( $50 \mathrm{keV}$ to $1.4 \mathrm{MeV}$ ) on centerline at $25 \mathrm{~cm}$ behind the lead slabs (Item IID) Runs 1605.C, 1605.B, 1605.A . ..... 44

Table 28. Spectrum of high-energy neutrons $(>0.8 \mathrm{MeV})$ on centerline at $25 \mathrm{~cm}$ behind the lead slabs (Item IIIA): Run $7935 \ldots \ldots \ldots \ldots 45$

Table 29. Neutron spectrum ( $50 \mathrm{keV}$ to $1.4 \mathrm{MeV}$ ) on centerline at $25 \mathrm{~cm}$ behind the lead slabs (Item IIIA) Runs 1606.C, 1606.B, 1606.A ..... 46

Table 30. Spectrum of high-energy neutrons $(>0.8 \mathrm{MeV})$ on centerline at $25 \mathrm{~cm}$ behind the lead slabs (Item IIIB): Run $7936 \ldots \ldots \ldots \ldots \ldots 47$

Table 31. Neutron spectrum ( $50 \mathrm{keV}$ to $1.4 \mathrm{MeV}$ ) on centerline at $25 \mathrm{~cm}$ behind the lead slabs (Item IIIB) Runs 1607.C, 1607.B, 1607.A . . . . . 48

Table 32. Spectrum of high-energy neutrons $(>0.8 \mathrm{MeV})$ on centerline at $25 \mathrm{~cm}$ behind the lead slabs (Item IIIC): Run $7938 \ldots \ldots \ldots \ldots . \ldots 49$

Table 33. Neutron spectrum ( $50 \mathrm{keV}$ to $1.4 \mathrm{MeV}$ ) on centerline at $25 \mathrm{~cm}$ behind the lead slabs (Item IIIC) Runs 1608.B, 1608.C, 1608.A . . . . . 50 


\section{LIST OF FIGURES}

$\underline{\text { Page }}$

Figure 1. Schematic of SM-1 (Fe + Al + boral + radial blankets).

Items IA and IA plus lead. Note: Lithiated paraffin

covers four sides of the configuration $\ldots \ldots \ldots \ldots \ldots \ldots$

Figure 2. Schematic of radial blanket slab containing $\mathrm{UO}_{2} \ldots \ldots \ldots \ldots$

Figure 3. Schematic of stainless steel containers used for boron

carbide shield slabs ....................... 55

Figure 4. Spectrum of high-energy neutrons (>0.8 MeV) on centerline at $25 \mathrm{~cm}$ behind the lead slabs (Item IA) Run $7931 \ldots \ldots \ldots \ldots$

Figure 5. Neutron spectrum (50 keV to $1.4 \mathrm{MeV}$ ) on centerline at $25 \mathrm{~cm}$ behind the lead slabs (Item IA) Runs 1602.C, 1602.B, 1602.A . . . . . 57

Figure 6. Schematic of SM-1 plus shield configuration for Items IIA, IIB,

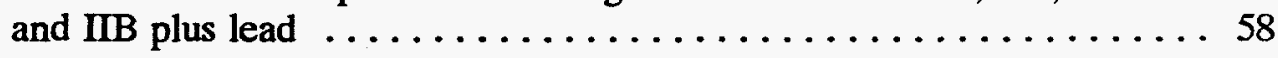

Figure 7. Spectrum of high-energy neutrons (>0.8 MeV) on centerline at $25 \mathrm{~cm}$ behind the lead slabs (Item IIB) Run $7932 \ldots \ldots \ldots$

Figure 8. Neutron spectrum (50 keV to $1.4 \mathrm{MeV}$ ) on centerline at $25 \mathrm{~cm}$ behind the lead slabs (Item IIB) Runs 1603.C, 1603.B,

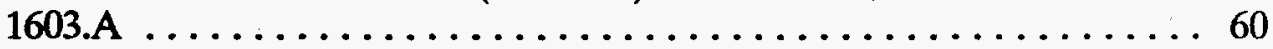

Figure 9. 3-inch Bonner ball traverses through the horizontal midplane at $30 \mathrm{~cm}$ behind a series of configurations (Items IIB-D, IIIB, C) . . . 61

Figure 10. 5-inch Bonner ball traverses through the horizontal midplane at $30 \mathrm{~cm}$ behind a series of configurations (Items IIB-D, IIIB, C) . . . 62

Figure 11. 8-inch Bonner ball traverses through the horizontal midplane at $30 \mathrm{~cm}$ behind a series of configurations (Items IIB-D, IIIB, C) $\ldots .63$

Figure 12. Schematic of SM-1 plus shield configuration for Items IIC

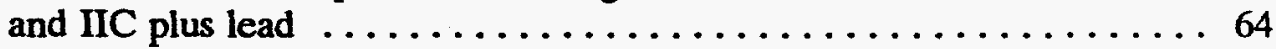

Figure 13. Spectrum of high-energy neutrons ( $>0.8 \mathrm{MeV})$ on centerline at $25 \mathrm{~cm}$ behind the lead slabs (Item IIC) Run $7933 \ldots \ldots \ldots \ldots 6$

Figure 14. Neutron spectrum (50 keV to $1.4 \mathrm{MeV}$ ) on centerline at $25 \mathrm{~cm}$ behind the lead slabs (Item IIC) Runs 1604.C, 1604.B, 1604.A . . . . . 66 
Figure 15. Schematic of SM-1 plus shield configuration for Items IID and IID plus lead.$\ldots \ldots \ldots \ldots \ldots \ldots \ldots \ldots \ldots \ldots$

Figure 16. Spectrum of high-energy neutrons $(>0.8 \mathrm{MeV})$ on centerline at $25 \mathrm{~cm}$ behind the lead slabs (Item IID) Run $7934 \ldots \ldots \ldots \ldots 68$

Figure 17. Neutron spectrum ( $50 \mathrm{keV}$ to $1.4 \mathrm{MeV}$ ) on centerline at $25 \mathrm{~cm}$ behind the lead slabs (Item IID) Runs 1605.C, 1605.B, 1605.A . . . . . 69

Figure 18. Schematic of SM-1 plus shield configuration for Items IIIA and IIIA plus lead

Figure 19. Spectrum of high-energy neutrons $(>0.8 \mathrm{MeV})$ on centerline at $25 \mathrm{~cm}$ behind the lead slabs (Item IIIA) Run $7935 \ldots \ldots \ldots \ldots 71$

Figure 20. Neutron spectrum ( $50 \mathrm{keV}$ to $1.4 \mathrm{MeV})$ on centerline at $25 \mathrm{~cm}$ behind the lead slabs (Item IIIA) Runs 1606.C, 1606.B, 1606.A .... 72

Figure 21. Schematic of SM-1 plus shield configuration for Items IIIB and IIIB plus lead $\ldots \ldots \ldots \ldots \ldots \ldots \ldots \ldots \ldots \ldots \ldots \ldots \ldots$

Figure 22. Spectrum of high-energy neutrons $(>0.8 \mathrm{MeV})$ on centerline at $25 \mathrm{~cm}$ behind the lead slabs (Item IIIB) Run $7936 \ldots \ldots \ldots \ldots .74$

Figure 23. Neutron spectrum ( $50 \mathrm{keV}$ to $1.4 \mathrm{MeV})$ on centerline at $25 \mathrm{~cm}$ behind the lead slabs (Item IIIB) Runs 1607.C, 1607.B, 1607.A . . . . . 75

Figure 24. Schematic of SM-1 plus shield configuration for Items IIIC and IIIC plus lead ............................ 76

Figure 25. Spectrum of high-energy neutrons $(>0.8 \mathrm{MeV})$ on centerline at $25 \mathrm{~cm}$ behind the lead slabs (Item IIIC) Run 7938

Figure 26. Neutron spectrum ( $50 \mathrm{keV}$ to $1.4 \mathrm{MeV})$ on centerline at $25 \mathrm{~cm}$ behind the lead slabs (Item IIIC) Runs 1608.B, 1608.C, 1608.A ................................ 78 


\begin{abstract}
The Special Materials Experiment was conducted at the Oak Ridge National Laboratory (ORNL) during 1992 as the final experiment in a series of eight experiments conducted for the Japanese-American Shielding Program for Experimental Research (JASPER) program that started in 1986. This experiment completes the experimental program providing support for the development of current designs proposed for advanced liquid metal reactor (LMR) systems both in Japan and the United States. The Tower Shielding Reactor II (TSR-II) source was modified to provide a neutron spectrum that would be typical of that to be found both radially and axially surrounding the LMR core.

The experimental program plan was divided into two phases. In phase I, the mockups consisted of stainless steel followed by slabs of polyethylene and zirconium. For phase II, the stainless steel and zirconium were eliminated, leaving only the different thicknesses of polyethylene. Integral neutron flux measurements were obtained behind each of the mockups accompanied by spectral measurements for each configuration except one.
\end{abstract}




\section{INTRODUCTION}

This experiment is the last in a series of eight experiments conducted at the Tower Shielding Facility (TSF) that were jointly planned by ORNL, participant for the United States Department of Energy (U.S. DOE), and the Japan Power Reactor and Nuclear Fuel Development Corporation (PNC). This phase of the program, called the Special Materials Experiment, was preceded by the Radial Shield Attenuation and Fission Gas Plenum Experiments completed in 1986-87, the Axial Shield Experiment completed in 1990, the In-Vessel Fuel Storage (IVFS) Experiment completed during 1991, and the Intermediate Heat Exchanger (IHX) Activation Experiment, the Gap Streaming Experiment, and the Flux Monitor Experiment, all of which were completed during 1992.

The Special Materials Experiment was designed to compare the effectiveness of selected shielding materials for use in the advanced liquid metal reactor systems. The material of particular interest for this experiment was zirconium hydride, but it was not readily available in large dimensions needed for the experiment. In its place the one slab of zirconium that was available at the TSF was combined with slabs of polyethylene to simulate the hydrogen that would be found in the zirconium hydride. Boron carbide was added to the mockups to complete the configurations as requested. The mockups were preceded by a spectrum modifier to generate the proper incident neutron spectrum. The mockups and the corresponding measurements made are described in the program plan in Appendix A. 


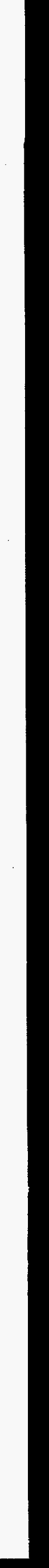




\section{INSTRUMENTATION}

The TSF Bonner ball detection system consists of a proportional counter surrounded by a series of different-sized polyethylene balls, each of which measures an integral of the neutron flux weighted by the energy-dependent response function for that ball. The detection device of a Bonner ball consists of a $5.1-\mathrm{cm}$-diameter spherical proportional counter filled with $\mathrm{BF}_{3}$ gas $\left({ }^{10} \mathrm{~B} / \mathrm{B}\right.$ concentration $\left.=0.96\right)$ to a pressure of 0.5 atmospheres. In order to cover a range of neutron energies, the counter may be used bare, covered with cadmium, or enclosed in various thicknesses of polyethylene shells surrounded by cadmium, each detector being identified by the diameter of its shell. Bonner ball experimental results are predicted analytically by folding a calculated neutron spectrum with the Bonner ball response functions determined by R. E. Maerker et al. ${ }^{1}$ and C. E. Burgart et al. ${ }^{2}$

An NE 213 liquid scintillator spectrometer was used to measure the neutron spectral region from about $800 \mathrm{keV}$ to $15 \mathrm{MeV}$. This device makes use of pulse-shape discrimination (PSD) to distinguish between neutron and gamma-ray pulses. Pulse-height data obtained with the spectrometer were unfolded with the FERD $\operatorname{code}^{3}$ to yield absolute neutron energy spectra.

Spherical proton-recoil counters, filled with hydrogen to pressures of 1,3 , and 10 atmospheres, measured the neutron energy range from about $50 \mathrm{keV}$ to $1 \mathrm{MeV}$. Pulseheight data from the counters were unfolded with the SPEC- 4 code, ${ }^{4}$ which makes use of the unfolded NE 213 neutron spectrum to correct for effects of higher-energy neutrons.

The measurements for each detector were referenced to the reactor power (watts) based on the data from two fission chambers positioned along the reactor centerline. The response of these chambers as a function of reactor power level was established previously through several calorimetric measurements of the heat generated in the reactor during a temperature equilibrium condition (heat power run). 



\section{EXPERIMENTAL CONFIGURATION}

The experimental program plan called for measurements behind mockups that included slabs of stainless steel, polyethylene, zirconium, and boron carbide in selected arrangements. The three plain polyethylene slabs purchased for use in the mockups were only available in widths less than the normal $152.4 \mathrm{~cm}$, thus requiring the use of extra lithiated paraffin around the periphery of the polyethylene.

The neutron source was the TSR-II whose emergent flux was modified using iron, aluminum, boral, and two slabs of the radial blankets. It should be noted that the material thicknesses mentioned in the program plan are nominal, the actual thicknesses are given in the left corner of the slabs shown in the various schematics displayed in Appendix C.

\subsection{SPECTRUM MODIFIER}

The test configurations were preceded by the radial shield spectrum modifier of iron, aluminum, boral, and "radial blanket" as shown in Figure 1. The iron component consisted of two rectangular slabs 5.20 - and 5.13 -cm-thick, both $152.4 \mathrm{~cm}$ (60-in) on an edge. The combined thickness of the three aluminum slabs was $9.12 \mathrm{~cm}$ followed by 2.54 $\mathrm{cm}$ of boral, all of the slabs having the same edge length as the iron slabs. Compositions of the iron, aluminum, and boral are given in Tables 1, 2, and 3 respectively. (Note: All tables are included in Appendix B.)

The uranium oxide $\left(\mathrm{UO}_{2}\right)$ slabs, commonly referred to as the "radial blanket" in this report, were fabricated for earlier experiments performed in the Liquid Metal Fast Breeder Reactor (LMFBR) program. They contained natural $\mathrm{UO}_{2}$ pellets, $1.397-\mathrm{cm}$ outside diameter (OD), enclosed in 1.524-cm OD aluminum cylinders. Between the aluminum and the pellets was a 0.00508 - to $0.01016-\mathrm{cm}$ annulus filled with argon. The cylinders were stacked side-by-side vertically having a triangular pitch of $1.608 \mathrm{~cm}$. The space between the aluminum cylinders was filled with sodium. This arrangement of the rods and sodium was enclosed in an iron vessel having an overall thickness of $11.05 \mathrm{~cm}$ and a length of $152.4 \mathrm{~cm}$ on each side.

Each of the two radial blanket slabs used in this modifier contained 522 rods of $\mathrm{UO}_{2}$ amounting to $64.6 \%$ of the volume of the slab. The rods were divided into seven rows, with alternating rows of 74 and 75 rods. The density of the $\mathrm{UO}_{2}$ was $10.28 \mathrm{~g} / \mathrm{cc}$ 
(94\% of theoretical). The volume fraction of the aluminum cladding was $11.2 \%$ while that for the sodium and argon are $23.3 \%$ and about $1 \%$ respectively. The pellet stack length in each of the rods was approximately $121.9 \mathrm{~cm}$. These rods were built by Numes Corporation in 1962 to conform, in general, to the then AEC/RDT design standards for the Fast Flux Test Facility (FFTF). A schematic of the slab is shown in Figure 2, with analyses of the $\mathrm{UO}_{2}$ and aluminum given in Tables 4 and 5 .

This spectrum modifier (SM1) was surrounded by $20.3 \mathrm{~cm}$ (8-in) of lithiated paraffin followed by up to $152.4 \mathrm{~cm}$ (60-in) of concrete to minimize the neutrons scattering back into the slabs and to reduce the amount of background radiation reaching the detectors. The lithiated paraffin was shaped as small bricks $10.16 \mathrm{~cm}$ on edge and 20.3 $\mathrm{cm}$ long (4-in-facing $\times$ 8-in-long) and the concrete consisted of blocks $61 \mathrm{~cm}$ on each edge and $30.48 \mathrm{~cm}$ thick. The composition of the lithiated paraffin and the concrete blocks are presented in Tables 6 and 7 respectively.

\subsection{ALUMINUM SLAB}

The aluminum slab that was placed in the mockup as part of the radial shield to mockup the sodium passing through the shield is of the same type (6061) aluminum contained in the aluminum slabs in the spectrum modifier. Composition of that type aluminum, noted earlier, is given in Table 2.

\subsection{STAINLESS STEEL SLABS}

Stainless steel slabs, type 304, were used as part of the radial shield mockup. The slabs were $5.15,5.15$, and $5.27 \mathrm{~cm}$ thick and $152.4 \mathrm{~cm}$ on an edge. Their elemental composition can be found in Table 8 .

\subsection{POLYETHYLENE SLABS}

The three polyethylene slabs were purchased just for this experiment. The slabs were 5.22, 5.31 , and $5.31 \mathrm{~cm}$ thick, each being $122 \mathrm{~cm}$ on an edge. The composition of the polyethylene is given in Table 9. 


\subsection{ZIRCONIUM SLAB}

The zirconium slab consisted of five individual pieces $122 \mathrm{~cm}$ long and $20.3 \mathrm{~cm}$ wide. The pieces were contained within an iron frame with inside dimensions of $122 \mathrm{~cm}$ square. The width of the five pieces, when placed edge-to-edge within the frame, was only $101.6 \mathrm{~cm}$, leaving a $20.3 \mathrm{~cm}$ void between the zirconium and the top piece of the 7.62-cm-wide iron channel frame that enclosed the zirconium. When placed in the mockup, this void was filled with a 5.07-cm-thick piece of polyethylene. Analysis of this polyethylene piece indicated it contained 27.5 micrograms of boron per gram of polyethylene. In the mockup the center of the zirconium pieces coincided with the reactor beam centerline. Analysis of the zirconium slab is given in Table 10.

\subsection{BORON CARBIDE}

The boron carbide $\left(\mathrm{B}_{4} \mathrm{C}\right)$ slab used in this experiment consisted of a stainless steel can filled with 120 grit boron carbide powder having a density of $1.42 \mathrm{~g} / \mathrm{cc}$. The slab, denoted as $1 \mathrm{~W}$, was $16.95 \mathrm{~cm}$ thick (stainless steel included) measured along the centerline as indicated in Figure 3. Spacer pins placed near the center of the slab were used to maintain constant thickness between the thin walls. The slab was $152.4 \mathrm{~cm}$ on an edge. The composition of the powder is given in Table 11. The amount of boron nitride (BN) as a component in this slab was not established. However, previous analysis (see ORNL/TM-11839) ${ }^{5}$ indicated there was about 1.8 percent present in previous $\mathrm{B}_{4} \mathrm{C}$ samples.

\subsection{SMALL CONCRETE BLOCKS}

The small concrete blocks, $15.24 \mathrm{~cm}$ square by $30.5 \mathrm{~cm}$ long, were placed outside the lithiated paraffin bricks placed on the sides of the slabs beyond the stainless steel radial shield. The analysis of the blocks is given in Table 12. The $\mathrm{H}_{2} \mathrm{O}$ content of these blocks was found to be $7.5 \pm 0.5 \mathrm{wt} \%$ in an experiment ${ }^{6}$ conducted at the TSF. 


\subsection{LEAD SLABS}

Lead slabs were placed in the beam between the mockup and the spectrometers when the spectral measurements are were made. Analysis of the lead slabs is contained in Table 13.

\subsection{BACKGROUND SHIELD}

It has been the custom in past measurements to obtain background measurements along with foreground measurements when the detectors were located at sufficient distances behind the mockups where neutron contributions to the detector from areas other than the mockup itself might not be negligible. For these measurements, a container of lithiated paraffin bricks, $91.4 \mathrm{~cm}$ x $91.4 \mathrm{~cm}$ x $40.6 \mathrm{~cm}$ thick, was usually placed between the detector and mockup in such a manner that contributions directly to the detector from just the mockup would be greatly reduced. This same procedure was used in this experiment to measure backgrounds when the Bonner balls were located on centerline at $150 \mathrm{~cm}$ beyond the mockup. 


\section{MEASUREMENTS}

The typical mockup consisted of a series of slabs stacked in proper sequence with their centers coincident with the reactor beam centerline. The slabs are usually surrounded by $20.3 \mathrm{~cm}$ of lithiated paraffin bricks on the sides and bottom, with the top of the slabs covered by a minimum of $20.3 \mathrm{~cm}$ but that thickness could be greater depending on the vertical height of the slabs. For the mockups where the polyethylene and zirconium slabs were included, it was necessary to use additional lithiated paraffin to center these slabs because they were only $122 \mathrm{~cm}$ on an edge (the typical slab is 152.4 $\mathrm{cm}$ ). When the zirconium slabs were used, the upper $20.3 \mathrm{~cm}$ of the slab (see Section 3.5 ) was filled with polyethylene to extend the slab to $122 \mathrm{~cm}$ since the vertical height of the zirconium itself was only $101.6 \mathrm{~cm}$. Concrete blocks were then placed beyond the lithiated paraffin that surrounded the mockups to attenuate the neutrons beyond the edges of the mockups and, as a result, minimize the number of "background" neutrons that would reach the detectors.

Background measurements were obtained with the Bonner balls on centerline at $150 \mathrm{~cm}$ beyond the mockup. To make these measurements, a $40.6-\mathrm{cm}$-thick lithiated paraffin-filled slab, $91 \mathrm{~cm}$ on a side, was placed approximately halfway between the detector and the last slab in the mockup so that the neutrons leaving the last slab in the mockup and moving directly toward the detector would be prevented from reaching it. For those configurations where the narrower polyethylene or zirconium slabs were the last slab, the background shadow shield was located in the same manner as for the full width $(152.4 \mathrm{~cm})$ slabs again blocking out the same area, only this time this area included part of the lithiated paraffin surrounding the slabs. This procedure was used to maintain consistency throughout the measurements.

The order in which the measurements were performed followed the order as listed in the program plan. Throughout this report the words configuration, item, and mockup are used interchangeably when referring to the contents of the program plan.

\subsection{SPECTRUM MODIFIER (ITEM IA)}

The program plan called for measurements behind a spectrum modifier composed of iron, aluminum, boral, and "radial blankets" as shown in the schematic in Figure 1. Two 
slabs of lead were placed behind the radial blanket for the measurement of the neutron

spectrum. The high-energy part of the spectrum was obtained with the NE 213 scintillator located on the beam centerline at $25 \mathrm{~cm}$ behind the lead. The resulting spectrum is listed in Table 14 and plotted in Figure 4. Three hydrogen-filled proton recoil counters filled to 1,3 , and 10 atmospheres of pressure were used to measure the lower energy part of the spectrum. These data are given in Table 15 and plotted in Figure 5. The 3-, 5-, and 10inch Bonner ball measurements at the NE 213 location are included in Table 16. The lead slabs were removed to make the centerline measurements with the 3-, 5-, 8-, and 10inch Bonner balls at 30 and $150 \mathrm{~cm}$. The data obtained at $30 \mathrm{~cm}$ are given in Table 17 , while both the foreground and background measurements at $150 \mathrm{~cm}$ are part of Table 18 .

\section{SM-1 + ZIRCONIUM (ITEMS IIA-D)}

Aluminum and stainless steel slabs were placed in the mockup to represent part of the removable radial shield. This mockup (Item IIA) is shown in the schematic in Figure 6. The only measurements behind this mockup were the 3-, 5-, 8-, and 10-inch Bonner balls on centerline at 30 and $150 \mathrm{~cm}$. The results from the measurements at $30 \mathrm{~cm}$ are given in Table 17, and those obtained at $150 \mathrm{~cm}$ are part of Table 18.

A 5.31-cm-thick slab of polyethylene was added to the mockup as also shown in Figure 6 (Item IIB). A single slab of lead was added to improve the neutron-to-gammaray ratio for obtaining the spectral measurements. Results from the measurement at 25 $\mathrm{cm}$ behind the lead with the NE 213 scintillator are given in Table 19 and plotted in Figure 7. Results from measurements with the hydrogen-filled counters at $25 \mathrm{~cm}$ are listed also in Table 20 and plotted in Figure 8. The Bonner ball measurements at this same location are part of Table 16. The Bonner ball measurements on centerline at 30 and $150 \mathrm{~cm}$ without the lead present are listed in Tables 17 and 18 . Results from the radial traverses at $30 \mathrm{~cm}$ behind the mockup with the 3-, 5-, and 8-inch Bonner balls are given in Tables 21, 22, and 23 with plots in Figures 9, 10, and 11 respectively.

The slab of zirconium was placed in the mockup as shown in Figure 12 (Item IIC). Again a slab of lead was added to make the spectral measurements. Data obtained with the NE 213 on centerline at $25 \mathrm{~cm}$ behind the lead are given in Table 24 and plotted in Figure 13. The lower-energy spectrum obtained with the hydrogen-filled detectors is listed in Table 25 and plotted in Figure 14. The Bonner ball measurements at this same 
location are part of Table 16. The radial traverse data at $30 \mathrm{~cm}$ with the Bonner balls without the lead slab in the mockup are given in Tables 21,22 , and 23 and plotted in Figures 9, 10, and 11. The centerline measurements at 30 and $150 \mathrm{~cm}$ with the Bonner balls are given in Tables 17 and 18.

Placement of $16.95 \mathrm{~cm}$ of boron carbide in the mockup behind the zirconium (Item IID), as shown in Figure 15, completed the series of configurations for this phase of the program plan. Again a lead slab was used to make the spectral measurements. The high-energy data obtained at $25 \mathrm{~cm}$ behind the lead are given in Table 26 and plotted in Figure 16. The lower-energy data are listed in Table 27 and plotted in Figure 17. The Bonner ball data at the same location are given in Table 17. The lead was removed for measurements with the Bonner balls on the centerline at 30 and $150 \mathrm{~cm}$ and these data are listed in Tables 17 and 18. The radial traverse results with the three Bonner balls are contained in Tables 21, 22, and 23, and plotted in Figures 9, 10, and 11.

\subsection{SM-1 + POLYETHYLENE (TTEMS IIIA-C)}

For the first of these series of measurements the mockup consisted of the spectrum modifier plus $10.53 \mathrm{~cm}$ of polyethylene (Item IIIA) as shown in Figure 18. Two slabs of lead were added for the spectral measurements. The NE 213 scintillator was placed on centerline at $25 \mathrm{~cm}$ behind the lead, and the resulting spectrum is located in Table 28 and plotted in Figure 19. The spectral information obtained with the three hydrogen-filled detectors are listed in Table 29 and plotted in Figure 20. The 3-, 5-, and 10-inch Bonner ball data at the same location are part of Table 16.

Centerline measurements with the 3-, 5-, and 8-inch Bonner balls were obtained at 30 and $150 \mathrm{~cm}$ after the lead slabs were removed. These results are contained in Tables 17 and 18 respectively. No radial traverses were made behind this particular mockup.

Another 5.21-cm-thick polyethylene slab was added to get the second mockup (Item IIIB) listed in Phase III of the program plan. Again, two slabs of lead, $3.81 \mathrm{~cm}$ each, were added for the spectral measurements as shown in Figure 21. Data obtained with the NE 213 on centerline at $25 \mathrm{~cm}$ behind the lead are listed in Table 30 and plotted in Figure 22. The low-energy spectrum data obtained with the proton-recoil detectors are listed in Table 31 and plotted in Figure 23. Bonner ball results at this same location are in Table 16. 
Bonner ball centerline measurements with the lead slabs removed are given in Table 17 for the $30 \mathrm{~cm}$ location and for those at $150 \mathrm{~cm}$ the results are in Table 18. Radial traverses were included for this mockup and these results using the 3-, 5-, and 8inch Bonner balls are given in Tables 21, 22, and 23 respectively and plotted in Figures 9 , 10 , and 11.

The last mockup listed in the program plan (Item IIIC) contained the $16.95 \mathrm{~cm}$ slab of $\mathrm{B}_{4} \mathrm{C}$ following the polyethylene as shown in Figure 24. The same two slabs of lead were added for the spectral measurements. These results are given in Table 32 and plotted in Figure 25 for the high-energy part of the neutron spectrum and for the lowerenergy part of the spectrum they are listed in Table 33 and plotted in Figure 26. Data from the Bonner ball measurements at this location are in Table 16.

The radial traverse results using the 3-, 5-, and 8-inch Bonner balls at $30 \mathrm{~cm}$ behind the $\mathrm{B}_{4} \mathrm{C}$, with no lead present, are given in Tables 21, 22, and 23, and plotted in Figures 9,10 , and 11 . 


\section{ANALYSIS OF EXPERIMENTAL ERRORS}

The errors associated with the measurements are due to a number of uncertainties: (1) the sizes of the gaps between slabs, unavoidably introduced in the configurations, (2) in the positions of the detectors, (3) the detector count rate statistics and calibrations, (4) the reactor power determinations, and (5) the effects of the exposure of the configurations to the weather. Of these, the uncertainty due to the weather is the least understood and probably beyond simple estimation. The uncertainty lies in the amount of moisture collecting between the slabs and in the lithiated paraffin surrounding them. During this experiment, however, the mockups were covered with a plastic tarpaulin that would somewhat limit the amount of moisture reaching the slabs. Thus, for this experiment, the effect of the weather was assumed to be negligible.

The TSR-II power level for each measurement was determined from the output of two fission chambers located in the reactor shield along the midplane of the reactor. The response of these chambers to the reactor source was monitored prior to the experiment through the use of gold foils and this ratio, detector response to gold foil results, agreed within about $5 \%$ with a history of earlier such comparisons. These detectors were calibrated on a daily basis using a ${ }^{252} \mathrm{Cf}$ source, with the calibration values lying within about a $6 \%$ spread ( $\pm 3 \%$ of an average value). During any one detector traverse in a given day, the variation in the reactor power indicated by the monitor outputs was at most only $3 \%$; however, during the several months the experiment was being performed, the monitors indicated a spread in any one power level of about $\pm 5 \%$. Thus, the uncertainty in the reactor power determination was assumed to be $\pm 5 \%$.

Count-rate statistics are expressed in a manner specific to each detector. For the NE 213 measurements, counting statistics and unfolding errors are included in the unfolding of the pulse-height spectra using the FERD code, with the resulting flux expressed in terms of lower and upper limits that represent a $68 \%$ confidence interval. Similar errors are expressed in the tabular data for the hydrogen counter measurements unfolded using SPEC4. Neither of the spectra, NE 213 or hydrogen counter, reflects the error in determining the reactor power since this error is not included in the unfolding program. This, as seen above, could be as much as $\pm 5 \%$.

The Bonner ball detectors were calibrated on a daily basis using ${ }^{252} \mathrm{Cf}$ as a source, with the resulting count rates falling within about $\pm 3 \%$ of an average value obtained 
throughout the years. Movement of the Bonner balls along a traversing mechanism can vary the detector location with respect to the configuration several millimeters on either side of a straight line. For the measurements perpendicular to the configuration centerline at $30 \mathrm{~cm}$ behind the configuration, such variations in the detector position could amount to a change in the count rate of about $2 \%$. For the measurements on centerline beyond the $30 \mathrm{~cm}$ point, the error in positioning several millimeters either side of the selected location would lie within the statistics of the measurement. Rather than calculate probable errors for each measurement in a series of measurements during a traverse, we prefer, in general, to quote a value for the error in the measurements for a given experiment. Thus, assuming the estimated upper limit for all the errors, the errors assigned to the Bonner ball measurements should be less than $\pm 10 \%$.

The fission chamber used throughout this experiment as a companion detector to the Bonner balls was calibrated on a daily basis using the thermal neutron flux generated by placement of the ${ }^{252} \mathrm{Cf}$ source in a jug of lucite. The resulting count rates fell within about $\pm 5 \%$ of an average value obtained throughout the experiment. Movement of the fission chamber was similar to that of the Bonner ball described earlier and the procedure in determining the possible errors with this detector follow that described for the Bonner balls. 


\section{ACKNOWLEDGEMENTS}

The authors are deeply indebted to D. T. Ingersoll and J. V. Pace, III, of ORNL's Engineering Physics and Mathematics Division, to P. B. Hemmig of DOE/Washington, and to the JASPER working group from Japan for their participation and assistance in formulating the Experimental Program Plan. A deep gratitude is expressed to the TSR-II operating crew of the Research Reactors Division and TSF assigned members of the Instrumentation and Controls Division for not only maintaining a viable source but for experimental help when needed. Appreciation is expressed to E. R. Specht, Rockwell International, W. H. Harless, General Electric Company, R. K. Disney, WestinghouseARD, W. L. Bunch, Westinghouse-Hanford for timely suggestions. Special thanks go to G. A. Marvin and S. A. Raby for their efforts in editing and preparing this report.

\section{REFERENCES}

1. R.E. Maerker et al., Calibration of the Bonner Ball Neutron Detectors Used at the Tower Shielding Facility, ORNL/TM-3465 (June 1971).

2. C. E. Burgart and M. B. Emmett, Monte Carlo Calculations of the Response Functions of Bonner Ball Neutron Detectors, ORNL/TM-3739 (April 1972).

3. B. W. Rust, D. T. Ingersoll, and W. R. Burrus, $A$ User's Manual for the FERDO and FERD Unfolding Codes, ORNL/TM-8720 (September 1983).

4. J. O. Johnson and D. T. Ingersoll, User's Guide for the Revised SPEC-4 Neutron Spectrum Unfolding Code, ORNL/TM-7384 (August 1980).

5. F. J. Muckenthaler et al., Measurements for the JASPER Program Axial Shield Experiment, ORNL/TM-11839 (August 1991).

6. R. R. Spencer et al., Measurement of Water Content of Concrete Shielding Used in JASPER Program, ORNL/TM-12325 (to be published). 



\section{APPENDIX A \\ EXPERIMENTAL PROGRAM PLAN FOR THE JASPER SPECIAL MATERIALS EXPERIMENT}

I. Spectrum Modifier (SM-1)

A. $\quad \mathrm{SM}-1(10 \mathrm{~cm} \mathrm{Fe}+9 \mathrm{~cm} \mathrm{Al}+2.5 \mathrm{~cm}$ boral $+20 \mathrm{~cm}$ Radial Blanket $)$

1. NE 213/Benjamin spectrometer measurements on centerline as close as feasible behind shield mockup

2. 3-, 5-, and 10-in Bonner ball measurements on centerline at NE 213 location

3. 3-, 5-, 8-, and 10-in Bonner ball measurements on centerline:

a. $\quad 30 \mathrm{~cm}$ behind shield mockup

b. $\quad 150 \mathrm{~cm}$ behind shield mockup (foreground and background)

II. $\quad \mathrm{SM}-1+$ zirconium

A. $\quad \mathrm{SM}-1+1.3 \mathrm{~cm} \mathrm{Al}+15 \mathrm{~cm} \mathrm{SS}$

1. 3-, 5-, 8-, and 10-in Bonner ball measurements on centerline:

a. $\quad 30 \mathrm{~cm}$ behind shield mockup

b. $\quad 150 \mathrm{~cm}$ behind shield mockup (foreground and background)

B. $\quad \mathrm{SM}-1+1.3 \mathrm{~cm} \mathrm{Al}+15 \mathrm{~cm} \mathrm{SS}+5 \mathrm{~cm}$ polyethylene

1. NE 213/Benjamin spectrometer measurements on centerline as close as feasible behind shield mockup

2. 3-, 5-, and 10-in Bonner ball measurements on centerline at NE 213 location

3. 3-, 5-, 8-, and 10-in Bonner ball measurements on centerline:

a. $\quad 30 \mathrm{~cm}$ behind shield mockup

b. $\quad 150 \mathrm{~cm}$ behind shield mockup (foreground and background)

4. $\quad 3$-, 5-, and 8-in Bonner ball horizontal traverse at $30 \mathrm{~cm}$ behind shield mockup

C. $\quad \mathrm{SM}-1+1.3 \mathrm{~cm} \mathrm{Al}+15 \mathrm{~cm} \mathrm{SS}+5 \mathrm{~cm}$ polyethylene $+5 \mathrm{~cm}$ zirconium

1. NE 213/Benjamin spectrometer measurements on centerline as close as feasible behind shield mockup

2. 3-, 5-, and 10-in Bonner ball measurements on centerline at NE 213 location

3. 3-, 5-, 8-, and 10-in Bonner ball measurements on centerline:

a. $\quad 30 \mathrm{~cm}$ behind shield mockup

b. $\quad 150 \mathrm{~cm}$ behind shield mockup (foreground and background)

4. 3-, 5-, and 8-in Bonner ball horizontal traverse at $30 \mathrm{~cm}$ behind shield mockup 
D. $\quad \mathrm{SM}-1+1.3 \mathrm{~cm} \mathrm{Al}+15 \mathrm{~cm} \mathrm{SS}+5 \mathrm{~cm}$ polyethylene $+5 \mathrm{~cm}$ zirconium + $15 \mathrm{~cm} \mathrm{~B} \mathrm{~B}_{4}$

1. NE 213/Benjamin spectrometer measurements on centerline as close as feasible behind shield mockup

2. 3-, 5-, and 10-in Bonner ball measurements on centerline at NE 213 location

3. 3-, 5-, 8-, and 10-in Bonner ball measurements on centerline:

a. $\quad 30 \mathrm{~cm}$ behind shield mockup

b. $\quad 150 \mathrm{~cm}$ behind shield mockup (foreground and background)

4. 3-, 5-, and 8-in Bonner ball horizontal traverse at $30 \mathrm{~cm}$ behind shield mockup

III. SM-1 + polyethylene

A. $\quad \mathrm{SM}-1+10 \mathrm{~cm}$ polyethylene

1. NE 213/Benjamin spectrometer measurements on centerline as close as feasible behind shield mockup

2. 3-, 5-, and 10-in Bonner ball measurements on centerline at NE 213 location

3. 3-, 5-, 8-, and 10-in Bonner ball measurements on centerline:

a. $\quad 30 \mathrm{~cm}$ behind shield mockup

b. $\quad 150 \mathrm{~cm}$ behind shield mockup (foreground and background)

B. $\quad \mathrm{SM}-1+10 \mathrm{~cm}$ polyethylene $+5 \mathrm{~cm}$ polyethylene

1. NE 213/Benjamin spectrometer measurements on centerline as close as feasible behind shield mockup

2. 3-, 5-, and 10-in Bonner ball measurements on centerline at NE 213 location

3. 3-, 5-, 8-, and 10-in Bonner ball measurements on centerline:

a. $\quad 30 \mathrm{~cm}$ behind shield mockup

b. $\quad 150 \mathrm{~cm}$ behind shield mockup (foreground and background)

4. 3-, 5-, and 8-in Bonner ball horizontal traverse at $30 \mathrm{~cm}$ behind shield mockup

C. $\mathrm{SM}-1+10 \mathrm{~cm}$ polyethylene $+5 \mathrm{~cm}$ polyethylene $+15 \mathrm{~cm} \mathrm{~B} \mathrm{~B}_{4} \mathrm{C}$

1. NE 213/Benjamin spectrometer measurements on centerline as close as feasible behind shield mockup

2. 3-, 5-, and 10-in Bonner ball measurements on centerline at NE 213 location

3. 3-, 5-, 8-, and 10-in Bonner ball measurements on centerline:

a. $\quad 30 \mathrm{~cm}$ behind shield mockup

b. $\quad 150 \mathrm{~cm}$ behind shield mockup (foreground and background)

4. 3-, 5-, and 8-in Bonner ball horizontal traverse at $30 \mathrm{~cm}$ behind shield mockup 
APPENDIX B

\section{TABLES OF DATA}



Table 1. Analysis of iron slabs $(\rho=7.86 \mathrm{~g} / \mathrm{cc})$ used in spectrum modifier

\begin{tabular}{lc}
\hline Element & wt \% \\
\hline & \\
$\mathrm{Fe}$ & 98.4 \\
$\mathrm{C}$ & .25 \\
$\mathrm{Cr}$ & .15 \\
$\mathrm{Cu}$ & .03 \\
$\mathrm{Mn}$ & 1.0 \\
$\mathrm{Mo}$ & .02 \\
$\mathrm{Ni}$ & .05 \\
$\mathrm{Si}$ & .25 \\
\hline
\end{tabular}

Table 2. Analysis of 6061 aluminum ( $p=270 \mathrm{~g} / \mathrm{cc}$ )

\begin{tabular}{lcr}
\hline & & \\
Element & wt \% & $\mathrm{ppm}$ \\
& & \\
$\mathrm{Al}$ & 97.5 & \\
$\mathrm{Cr}$ & .22 & \\
$\mathrm{Cu}$ & .23 & \\
$\mathrm{Fe}$ & .47 & \\
$\mathrm{Mg}$ & .86 & \\
$\mathrm{Mn}$ & .01 & \\
$\mathrm{Si}$ & .63 & \\
$\mathrm{Ti}$ & .042 & \\
$\mathrm{Zn}$ & .07 & \\
$\mathrm{Li}$ & & 3 \\
$\mathrm{Ni}$ & & 50 \\
$\mathrm{Sn}$ & & $<10$ \\
$\mathrm{~V}$ & & 150 \\
& & \\
\hline
\end{tabular}


Table 3. Composition of boral slabs used in spectrum modifier

\begin{tabular}{clcc}
\hline & \multicolumn{2}{c}{$\left(\mathrm{B}_{4} \mathrm{C}-40-43\right.$ vol \% in $\mathrm{B}_{4} \mathrm{C}-\mathrm{Al}$ mixture) } \\
\cline { 2 - 4 } Component & $\begin{array}{l}\text { Density } \\
(\mathrm{g} / \mathrm{cc})\end{array}$ & $\begin{array}{c}\text { Elemental } \\
\text { Composition } \\
(\text { wt \%) }\end{array}$ & $\begin{array}{c}\text { With } \\
\text { Al Cladding } \\
(\text { wt \%) }\end{array}$ \\
\hline & & & \\
$\mathrm{B}_{4} \mathrm{C}$ & 2.3 & & $\sim 75$ \\
$\mathrm{Al}$ & 2.70 & 65 & -19.6 \\
$\mathrm{~B}$ & & 27.5 & $\sim 5.4$ \\
$\mathrm{C}$ & & 7.5 & \\
\hline
\end{tabular}


Table 4. Composition of $\mathrm{UO}_{2}$ radial blanket

\begin{tabular}{lcc}
\hline Component & vol \% & $\begin{array}{c}\text { Density } \\
(\mathrm{g} / \mathrm{cc})\end{array}$ \\
\hline & & \\
$\mathrm{UO}_{2}$ (pellets) & 64.6 & 10.28 \\
$\mathrm{Al}(8001)$ & 11.2 & 2.8 \\
$\mathrm{Na}$ & 23.2 & 0.92 \\
Void & 1.0 & $-\cdots$ \\
\hline
\end{tabular}

$\mathrm{U}$ content 88.18 wt $\%$ of $\mathrm{UO}_{2}$

\begin{tabular}{|c|c|c|c|c|c|}
\hline \multicolumn{6}{|c|}{ Isotope \% } \\
\hline & ${ }^{234} \mathrm{U}$ & $\begin{array}{l}.0053 \\
.713\end{array}$ & ${ }^{236} \mathrm{U}$ & 99.28 & \\
\hline \multicolumn{6}{|c|}{ Metallic Impurities in $\mathrm{UO}_{2}(\mathrm{ppm})$} \\
\hline $\mathrm{Al}$ & $<20$ & $\mathrm{Cu}$ & 1 & $\mathrm{Na}$ & $<20$ \\
\hline B & $<1$ & $F$ & $<2$ & $\mathrm{Ni}$ & $<10$ \\
\hline $\mathrm{Be}$ & $<2$ & $\mathrm{Fe}$ & $<20$ & $\mathrm{~Pb}$ & $<4$ \\
\hline $\mathrm{Bi}$ & $<2$ & $\mathrm{H}_{2} \mathrm{O}$ & 2.1 & $\mathrm{Si}$ & $<20$ \\
\hline $\mathrm{C}$ & $<10$ & $\mathrm{Li}$ & $<1$ & Sn & $<2$ \\
\hline $\mathrm{Ca}$ & $<20$ & $\mathrm{Mg}$ & $<10$ & $\mathrm{Ta}$ & $<25$ \\
\hline $\mathrm{Cd}$ & $<0.5$ & Mn & $<4$ & $\mathrm{Ti}$ & $<4$ \\
\hline $\mathrm{Cl}$ & $<3.3$ & Mo & $<10$ & $\mathbf{W}$ & $<25$ \\
\hline Co & $<2$ & $\mathbf{N}$ & 54 & $\mathrm{Zr}$ & $<25$ \\
\hline $\mathrm{Cr}$ & $<10$ & & & & \\
\hline
\end{tabular}

"ppm = parts per million 
Table 5. Analysis of aluminum used in $\mathrm{UO}_{2}$ radial blanket cladding ( $\rho=2.7 \mathrm{~g} / \mathrm{cc}$ )

\begin{tabular}{|c|c|c|}
\hline Element & wt $\%$ & ppm \\
\hline $\mathrm{Al}$ & Major & \\
\hline $\mathrm{Fe}$ & .59 & \\
\hline $\mathrm{Ni}$ & 1.13 & \\
\hline B & & $<6$ \\
\hline $\mathrm{Be}$ & & $<20$ \\
\hline $\mathrm{Cd}$ & & $<20$ \\
\hline Co & & $<20$ \\
\hline $\mathrm{Cr}$ & & $<6$ \\
\hline $\mathrm{Cu}$ & & 52.9 \\
\hline $\mathrm{Li}$ & & 6 \\
\hline $\mathrm{Mg}$ & & 3.04 \\
\hline $\mathrm{Mn}$ & & 11.2 \\
\hline Mo & & $<6$ \\
\hline $\mathrm{Pb}$ & & $<20$ \\
\hline $\mathbf{S i}$ & & 27.5 \\
\hline Sn & & $<60$ \\
\hline $\mathrm{Ta}$ & & $<2000$ \\
\hline $\mathrm{Ti}$ & & 65.5 \\
\hline V & & 44.2 \\
\hline W & & $<60$ \\
\hline $\mathrm{Zr}$ & & $<20$ \\
\hline
\end{tabular}

Table 6. Composition of lithiated-paraffin bricks $(\rho=1.15 \mathrm{~g} / \mathrm{cc})$

\begin{tabular}{lc}
\hline Component & wt \% \\
\hline $\mathrm{C}_{\mathrm{n}} \mathrm{H}_{2 n+2}$ & 60 \\
$\mathrm{Li}_{2} \mathrm{CO}_{3}$ & 40 \\
\hline
\end{tabular}


Table 7. Analysis of $61-\mathrm{cm} \times 61-\mathrm{cm} \times 30.5-\mathrm{cm}(\rho=2.40 \mathrm{~g} / \mathrm{cc})$ concrete blocks used to surround configuration

\begin{tabular}{cccc}
\hline Component & wt\% & Component & wt\% \\
\hline $\mathrm{CO}_{3}$ & 41.9 & $\mathrm{Al}_{2} \mathrm{O}_{3}$ & 2.2 \\
$\mathrm{Ca}$ & 27.4 & $\mathrm{Fe}_{2} \mathrm{O}_{3}$ & .60 \\
$\mathrm{SiO}_{2}$ & 18.1 & $\mathrm{SO}_{3}$ & .32 \\
$\mathrm{H}_{2} \mathrm{O}$ & 4.0 & $\mathrm{P}_{2} \mathrm{O}_{5}$ & .035 \\
$\mathrm{Mg}$ & 3.66 & $\mathrm{~K}$ & .30 \\
$\mathrm{O}_{2}$ & 1.4 & & \\
\hline
\end{tabular}


Table 8. Analysis of type 304 stainless steel $(\rho=7.92 \mathrm{~g} / \mathrm{cc}$ )

\begin{tabular}{lcc}
\hline \multirow{2}{*}{ Element } & \multicolumn{2}{c}{ wt\% } \\
& Lower & Upper \\
\hline $\mathrm{Fe}$ & 68.1 & -71.2 \\
$\mathrm{Cr}$ & 18.0 & -19.1 \\
$\mathrm{Ni}$ & 8.8 & -9.8 \\
$\mathrm{Mn}$ & 1.04 & -1.65 \\
$\mathrm{Si}$ & 0.33 & -0.65 \\
$\mathrm{C}$ & 0.024 & -0.085 \\
$\mathrm{O}_{2}$ & 0.013 & -0.021 \\
$\mathrm{P}$ & & 0.028 \\
$\mathrm{~S}$ & & 0.022 \\
$\mathrm{Mo}$ & & 0.30 \\
$\mathrm{Cu}$ & & 0.26 \\
$\mathrm{Co}$ & & 0.10 \\
& & \\
\hline
\end{tabular}


Table 9. Analysis of polyethylene slabs $(\rho=0.955 \mathrm{~g} / \mathrm{cc})$

\begin{tabular}{ccc}
\hline Element & wt \% & ppm \\
\hline $\mathrm{H}$ & 14.4 & \\
$\mathrm{C}$ & 85.6 & \\
$\mathrm{Na}$ & & $<140$ \\
$\mathrm{Cr}$ & & $<140$ \\
$\mathrm{Si}$ & & $<140$ \\
$\mathrm{P}$ & & $<140$ \\
\hline
\end{tabular}

Table 10. Analysis of zirconium

\begin{tabular}{cc}
\multicolumn{2}{c}{$(\rho=6.54 \mathrm{~g} / \mathrm{cc})$} \\
\hline Element & wt \% \\
\hline $\mathrm{Hf}$ & 1.8 \\
$\mathrm{Zr}$ & 98.2 \\
\hline
\end{tabular}


Table 11. Analysis of boron carbide used in shield mockups

\begin{tabular}{|c|c|c|}
\hline Element & $w t \%$ & ppm \\
\hline B & 76.7 & \\
\hline $\mathrm{C}$ & 19.52 & \\
\hline $\mathrm{Al}$ & & 50 \\
\hline $\mathrm{Ca}$ & & 800 \\
\hline $\mathrm{Cl}$ & & 10 \\
\hline Co & & $<1$ \\
\hline $\mathrm{Cr}$ & & 2 \\
\hline $\mathrm{Cu}$ & & $<1$ \\
\hline $\mathrm{Fe}$ & & 600 \\
\hline $\mathrm{Mg}$ & & 25 \\
\hline $\mathrm{Mn}$ & & 10 \\
\hline $\mathrm{Na}$ & & 1 \\
\hline $\mathbf{P}$ & & 2 \\
\hline$S$ & & 5 \\
\hline $\mathbf{S i}$ & & 50 \\
\hline $\mathrm{Ti}$ & & 225 \\
\hline
\end{tabular}


Table 12. Composition of the small concrete blocks on each side of the mockup beyond spectrum modifier $(\rho=239 \mathrm{~g} / \mathrm{cc})$

\begin{tabular}{cc}
\hline Element & wt \% \\
\hline $\mathrm{C}$ & 10.36 \\
$\mathrm{O}$ & 49.03 \\
$\mathrm{Ca}$ & 38.05 \\
$\mathrm{Fe}$ & 0.37 \\
$\mathrm{Si}$ & 0.78 \\
$\mathrm{Mg}$ & 0.23 \\
$\mathrm{~S}$ & 0.17 \\
$\mathrm{P}$ & 0.04 \\
$\mathrm{Na}$ & 0.03 \\
$\mathrm{~K}$ & 0.04 \\
$\mathrm{H}$ & 0.42 \\
$\mathrm{R}$ & 0.47 \\
& 99.99
\end{tabular}

${ }^{*} \mathrm{R}$ is an unspecified mix of $\mathrm{Al}, \mathrm{Ti}, \mathrm{Cr}$, and possibly other traces of metals. 
Table 13. Analysis of lead slabs $(p=11.35 \mathrm{~g} / \mathrm{cc})$

\begin{tabular}{ccc}
\hline Element & wt\% & PPM \\
\hline $\mathrm{Pb}$ & 99.9 & \\
$\mathrm{Al}$ & & $<3$ \\
$\mathrm{Ag}$ & & 30 \\
$\mathrm{~B}$ & & $<1$ \\
$\mathrm{Ca}$ & & 1 \\
$\mathrm{Cr}$ & & 10 \\
$\mathrm{Cu}$ & 800 \\
$\mathrm{Fe}$ & 1 \\
$\mathrm{Li}$ & & 20 \\
$\mathrm{Mg}$ & & $<3$ \\
$\mathrm{Mn}$ & & 5 \\
$\mathrm{Na}$ & & 1 \\
$\mathrm{Ni}$ & 30 \\
$\mathrm{P}$ & & 5 \\
$\mathrm{Si}$ & $<3$ \\
$\mathrm{Sn}$ & & 30 \\
\hline
\end{tabular}


Table 14. Spectrum of high-energy neutrons $(>0.8 \mathrm{MeV})$ on centerline at $25 \mathrm{~cm}$ behind the lead slabs (Item IA): Run 7931.A

\begin{tabular}{|c|c|c|c|c|c|}
\hline \multirow[b]{2}{*}{$\begin{array}{c}\text { Neutron } \\
\text { Energy } \\
(\mathrm{MeV})\end{array}$} & \multicolumn{2}{|c|}{ Flux (neutrons $\mathrm{cm}^{-2} \mathrm{MeV}^{-1} \mathrm{~kW}^{-1} \mathrm{~s}^{-1}$ ) } & \multirow[b]{2}{*}{$\begin{array}{c}\text { Neutron } \\
\text { Energy } \\
(\mathrm{MeV})\end{array}$} & \multicolumn{2}{|c|}{ Flux (neutrons $\mathrm{cm}^{-2} \mathrm{MeV}^{-1} \mathrm{~kW}^{-1} \mathrm{~s}^{-1}$ ) } \\
\hline & $\begin{array}{l}\text { Lower } \\
\text { Limit }\end{array}$ & $\begin{array}{l}\text { Upper } \\
\text { Limit }\end{array}$ & & $\begin{array}{l}\text { Lower } \\
\text { Limit }\end{array}$ & $\begin{array}{l}\text { Upper } \\
\text { Limit }\end{array}$ \\
\hline $8.11 E-01$ & $1.84 E+05$ & $1.86 \mathrm{E}+05$ & $5.94 E+00$ & $1.80 E+03$ & $1.87 E+03$ \\
\hline $9.07 E-01$ & $1.68 E+05$ & $1.69 E+05$ & $6.25 E+00$ & $1.42 \mathrm{E}+03$ & $1.51 E+03$ \\
\hline $1.01 E+00$ & $1.28 \mathrm{E}+05$ & $1.28 \mathrm{E}+05$ & $6.55 \mathrm{E}+00$ & $1.15 E+03$ & $1.23 E+03$ \\
\hline $1.11 \mathrm{E}+00$ & $1.01 E+05$ & $1.01 E+05$ & $6.84 \mathrm{E}+00$ & $9.81 E+02$ & $1.03 E+03$ \\
\hline $1.20 \mathrm{E}+00$ & $8.79 E+04$ & $8.85 E+04$ & $7.24 \mathrm{E}+00$ & $7.83 E+02$ & $8.24 \mathrm{E}+02$ \\
\hline $1.31 E+\infty 0$ & $7.97 \mathrm{E}+04$ & $8.03 E+04$ & $7.74 E+00$ & $5.31 E+02$ & $5.80 \mathrm{E}+02$ \\
\hline $1.41 E+00$ & $7.32 E+04$ & $7.37 E+04$ & $8.24 E+00$ & $3.74 E+02$ & $4.21 E+02$ \\
\hline $1.51 E+00$ & $6.69 \mathrm{E}+04$ & $6.75 E+04$ & $8.76 \mathrm{E}+00$ & $2.87 E+02$ & $3.12 \mathrm{E}+02$ \\
\hline $1.61 \mathrm{E}+00$ & $6.05 E+04$ & $6.09 E+04$ & $9.26 \mathrm{E}+00$ & $2.15 E+02$ & $2.37 \mathrm{E}+02$ \\
\hline $1.71 E+00$ & $5.42 \mathrm{E}+04$ & $5.46 \mathrm{E}+04$ & $9.74 \mathrm{E}+00$ & $1.67 \mathrm{E}+02$ & $1.84 E+02$ \\
\hline $1.81 E+00$ & $4.84 E+04$ & $4.89 E+04$ & $1.03 E+01$ & $1.25 \mathrm{E}+02$ & $1.40 \mathrm{E}+02$ \\
\hline $1.93 E+00$ & $4.30 \mathrm{E}+04$ & $4.34 E+04$ & $1.08 E+01$ & $8.06 \mathrm{E}+01$ & $9.40 \mathrm{E}+01$ \\
\hline $2.10 E+00$ & $3.70 E+04$ & $3.74 E+04$ & $1.12 \mathrm{E}+01$ & $5.29 \mathrm{E}+01$ & $6.31 E+01$ \\
\hline $2.30 \mathrm{E}+00$ & $3.13 E+04$ & $3.16 \mathrm{E}+04$ & $1.18 \mathrm{E}+01$ & $3.49 \mathrm{E}+01$ & $4.33 E+01$ \\
\hline $2.50 E+00$ & $2.62 E+04$ & $2.65 E+04$ & $1.24 \mathrm{E}+01$ & $2.18 \mathrm{E}+01$ & $2.98 \mathrm{E}+01$ \\
\hline $2.70 E+00$ & $2.13 E+04$ & $2.15 E+04$ & $1.32 \mathrm{E}+01$ & $1.32 \mathrm{E}+01$ & $1.87 \mathrm{E}+01$ \\
\hline $2.90 \mathrm{E}+00$ & $1.68 E+04$ & $1.70 E+04$ & $1.40 \mathrm{E}+01$ & $4.32 \mathrm{E}+00$ & $9.10 \mathrm{E}+00$ \\
\hline $3.10 E+\infty 0$ & $1.29 \mathrm{E}+04$ & $1.32 E+04$ & $1.48 \mathrm{E}+01$ & $1.59 E+00$ & $5.48 \mathrm{E}+00$ \\
\hline $3.30 \mathrm{E}+00$ & $1.02 \mathrm{E}+04$ & $1.04 E+04$ & $1.56 \mathrm{E}+01$ & $2.53 E+00$ & $5.76 E+00$ \\
\hline $3.50 E+00$ & $8.15 E+03$ & $8.37 E+03$ & $1.65 \mathrm{E}+01$ & $1.91 E+00$ & $4.60 E+00$ \\
\hline $3.71 E+00$ & $6.67 E+03$ & $6.83 E+03$ & $1.75 \mathrm{E}+01$ & $-2.52 \mathrm{E}-01$ & $1.82 E+00$ \\
\hline $3.91 E+\infty 0$ & $5.68 \mathrm{E}+03$ & $5.82 E+03$ & $1.85 E+01$ & $-5.91 E-01$ & $1.07 E+00$ \\
\hline $4.15 E+00$ & $4.85 E+03$ & $4.99 E+03$ & $1.95 E+01$ & $-5.11 \mathrm{E}-01$ & $1.05 E+00$ \\
\hline $4.45 E+00$ & $4.16 E+03$ & $4.27 E+03$ & $2.05 E+01$ & $-1.22 \mathrm{E}+00$ & $1.17 E+00$ \\
\hline $4.75 E+00$ & $3.56 \mathrm{E}+03$ & $3.66 E+03$ & $2.16 \mathrm{E}+01$ & $-1.36 \mathrm{E}+00$ & $1.15 E+00$ \\
\hline $5.04 E+\infty 0$ & $3.02 E+03$ & $3.11 E+03$ & $2.26 \mathrm{E}+01$ & $-8.71 E-01$ & 8.35E -01 \\
\hline $5.34 \mathrm{E}+00$ & $2.56 \mathrm{E}+03$ & $2.64 E+03$ & $2.35 \mathrm{E}+01$ & $-7.16 \mathrm{E}-01$ & $7.49 \mathrm{E}-01$ \\
\hline $5.64 \mathrm{E}+00$ & $3.16 \mathrm{E}+03$ & $2.25 \mathrm{E}+03$ & & & \\
\hline
\end{tabular}

\begin{tabular}{cccc}
$\begin{array}{c}\mathrm{E} 1 \\
(\mathrm{MeV})\end{array}$ & $\begin{array}{c}\mathrm{E} 2 \\
(\mathrm{MeV})\end{array}$ & $\begin{array}{c}\text { Integral } \\
\text { neutrons } \mathrm{cm}^{-2} \mathrm{~kW}^{-1} \mathrm{~s}^{-1}\end{array}$ & $\begin{array}{c}\text { Error } \\
\text { neutrons } \mathrm{cm}^{-2} \mathrm{~kW}^{-1} \mathrm{~s}^{-1}\end{array}$ \\
\hline 0.811 & 1.000 & $3.11 \mathrm{E}+04$ & $1.01 \mathrm{E}+02$ \\
1.000 & 1.200 & $2.10 \mathrm{E}+04$ & $6.44 \mathrm{E}+01$ \\
1.200 & 1.600 & $2.97 \mathrm{E}+04$ & $1.08 \mathrm{E}+02$ \\
1.600 & 2.000 & $1.99 \mathrm{E}+04$ & $8.16 \mathrm{E}+01$ \\
2.000 & 3.000 & $2.67 \mathrm{E}+04$ & $1.42 \mathrm{E}+02$ \\
3.000 & 4.000 & $8.83 \mathrm{E}+03$ & $9.54 \mathrm{E}+01$ \\
4.000 & 6.000 & $6.57 \mathrm{E}+03$ & $9.73 \mathrm{E}+01$ \\
6.000 & 8.000 & $1.95 \mathrm{E}+03$ & $6.00 \mathrm{E}+01$ \\
8.000 & 10.000 & $5.51 \mathrm{E}+02$ & $2.74 \mathrm{E}+01$ \\
10.000 & 12.000 & $1.59 \mathrm{E}+02$ & $1.19 \mathrm{E}+01$ \\
12.000 & 16.000 & $4.55 \mathrm{E}+01$ & $1.00 \mathrm{E}+01$ \\
16.000 & 20.000 & $4.51 \mathrm{E}+00$ & $4.05 \mathrm{E}+00$ \\
3.000 & 10.000 & $1.79 \mathrm{E}+04$ & $2.81 \mathrm{E}+02$ \\
1.500 & 15.000 & $7.11 \mathrm{E}+04$ & $5.49 \mathrm{E}+02$ \\
3.000 & 12.000 & $1.81 \mathrm{E}+04$ & $2.92 \mathrm{E}+02$ \\
\hline
\end{tabular}


Table 15. Neutron spectrum ( $50 \mathrm{keV}$ to $1.4 \mathrm{MeV}$ ) on centerline at $25 \mathrm{~cm}$ behind the lead slabs (Item IA) Runs 1602.C, 1602.B, 1602.A

\begin{tabular}{|c|c|c|c|c|}
\hline $\mathbf{N}$ & \multicolumn{2}{|c|}{$\begin{array}{l}\text { Energy Boundary } \\
(\mathrm{MeV})\end{array}$} & $\underset{\text { (neutrons } \mathrm{cm}^{-2} \mathrm{MeV}^{-1} \mathrm{~kW}^{-1} \mathrm{~s}^{-1} \text { ) }}{\text { (nlux }}$ & $\begin{array}{l}\text { Error } \\
(\%)\end{array}$ \\
\hline \multicolumn{5}{|c|}{ RUN 1602.C } \\
\hline 1 & 0.0380 & 0.0451 & $5.46 \mathrm{E}+06$ & 1.63 \\
\hline 2 & 0.0451 & 0.0539 & $5.11 E+06$ & 1.55 \\
\hline 3 & 0.0539 & 0.0628 & $4.80 E+06$ & 1.84 \\
\hline 4 & 0.0628 & 0.0734 & $4.42 E+06$ & 1.79 \\
\hline 5 & 0.0734 & 0.0875 & $3.66 \mathrm{E}+06$ & 1.72 \\
\hline 6 & 0.0875 & 0.1035 & $2.82 E+06$ & 2.17 \\
\hline 7 & 0.1035 & 0.1211 & $2.77 E+06$ & 2.18 \\
\hline 8 & 0.1211 & 0.1424 & $2.53 E+06$ & 2.12 \\
\hline 9 & 0.1424 & 0.1671 & $2.04 E+06$ & 2.40 \\
\hline 10 & 0.1671 & 0.1972 & $1.80 \mathrm{E}+06$ & 2.35 \\
\hline 11 & 0.1972 & 0.2308 & $1.50 \mathrm{E}+06$ & 2.68 \\
\hline 12 & 0.2308 & 0.2732 & $1.26 E+06$ & 2.56 \\
\hline \multicolumn{5}{|c|}{$\underline{\text { RUN 1602.B }}$} \\
\hline 1 & 0.1942 & 0.2337 & $1.51 E+06$ & 1.10 \\
\hline 2 & 0.2337 & 0.2732 & $1.22 \mathrm{E}+06$ & 1.51 \\
\hline 3 & 0.2732 & 0.3193 & $1.06 E+06$ & 1.59 \\
\hline 4 & 0.3193 & 0.3786 & $7.40 \mathrm{E}+05$ & 1.88 \\
\hline 5 & 0.3786 & 0.4444 & $5.10 E+05$ & 2.70 \\
\hline 6 & 0.4444 & 0.5234 & $6.02 E+05$ & 2.03 \\
\hline 7 & 0.5234 & 0.6156 & $5.30 \mathrm{E}+05$ & 1.99 \\
\hline \multicolumn{5}{|c|}{ RUN 1602.A } \\
\hline 1 & 0.4521 & 0.5284 & $5.45 \mathrm{E}+05$ & 1.26 \\
\hline 2 & 0.5284 & 0.6156 & $5.28 \mathrm{E}+05$ & 1.17 \\
\hline 3 & 0.6156 & 0.7245 & $3.65 E+05$ & 1.33 \\
\hline 4 & 0.7245 & 0.8553 & $2.49 E+05$ & 1.62 \\
\hline 5 & 0.8553 & 1.0078 & $1.28 \mathrm{E}+05$ & 2.75 \\
\hline 6 & 1.0078 & 1.1821 & $9.01 E+04$ & 3.62 \\
\hline 7 & 1.1821 & 1.4000 & $7.91 E+04$ & 3.33 \\
\hline
\end{tabular}


Table 16. Bonner ball measurements on centerline at NE 213 location (Items IA, IIB-D, IIIA-C)

\begin{tabular}{|c|c|c|c|c|}
\hline \multirow[b]{2}{*}{ Configuration $^{a}$} & \multirow[b]{2}{*}{$\begin{array}{l}\text { Detector } \\
\text { Location }\end{array}$} & \multicolumn{3}{|c|}{ Bonner ball count rates $\left(\mathrm{s}^{-1} \mathrm{~W}^{-1}\right)$} \\
\hline & & $\begin{array}{c}\text { 3-in-Diam } \\
\text { Ball }^{c}\end{array}$ & $\begin{array}{c}\text { 5-in-Diam } \\
\text { Ball }{ }^{c}\end{array}$ & $\begin{array}{c}\text { 8-in-Diam } \\
\text { Ball } \\
\end{array}$ \\
\hline IA & $\begin{array}{c}25 \mathrm{~cm} \\
\text { behind lead }^{b}\end{array}$ & $4.69(2)^{d}$ & $2.17(3)$ & $7.65(2)$ \\
\hline IIB & $\begin{array}{c}25 \mathrm{~cm} \\
\text { behind lead }\end{array}$ & $2.95(1)$ & $5.79(1)$ & $1.63(1)$ \\
\hline IIC & $\begin{array}{c}25 \mathrm{~cm} \\
\text { behind lead }\end{array}$ & $1.45(1)$ & $3.37(1)$ & $9.89(0)$ \\
\hline III & $\begin{array}{c}25 \mathrm{~cm} \\
\text { behind lead }\end{array}$ & $1.72(-1)$ & $1.28(0)$ & $7.78(-1)$ \\
\hline IIIA & $\begin{array}{c}25 \mathrm{~cm} \\
\text { behind lead }\end{array}$ & $1.04(1)$ & $3.56(1)$ & $2.53(1)$ \\
\hline IIIB & $\begin{array}{c}25 \mathrm{~cm} \\
\text { behind lead }\end{array}$ & $2.63(0)$ & $1.01(1)$ & $8.36(0)$ \\
\hline IIIC & $\begin{array}{c}25 \mathrm{~cm} \\
\text { behind lead }\end{array}$ & $1.82(-1)$ & $1.91(0)$ & $1.87(0)$ \\
\hline
\end{tabular}

${ }^{a}$ See experimental program plan in Appendix A for description of configurations.

${ }^{b}$ Lead slab between configuration and detector (see schematics).

${ }^{c}$ Foreground only. Count rates without shadow shield between detector and configuration.

${ }^{d}$ Read: $4.69 \times 10^{2}$. 
Table 17. Bonner ball measurements on centerline at $30 \mathrm{~cm}$ behind mockups (Items IA, IIA-D, IIIA-C)

\begin{tabular}{|c|c|c|c|c|}
\hline \multirow[b]{2}{*}{$\underline{\text { Configuration }}^{\circ}$} & \multicolumn{4}{|c|}{ Bonner ball count rates $\left(s^{-1} W^{-1}\right)$} \\
\hline & 3-in-Diam Ball & 5-in-Diam Ball & 8-in-Diam Ball & 10-in-Diam Ball \\
\hline IA & $6.75(2)^{b}$ & $3.34(3)$ & $2.32(3)$ & $1.19(3)$ \\
\hline IIA & $2.41(2)$ & $9.69(2)$ & $6.44(2)$ & $3.18(2)$ \\
\hline IIB & $4.81(1)$ & $9.28(1)$ & 4.94 (1) & $2.39(1)$ \\
\hline IIC & $2.01(1)$ & $4.36(1)$ & $2.41(1)$ & $1.22(1)$ \\
\hline IID & $2.20(-1)$ & $1.65(0)$ & $1.60(0)$ & $1.01(0)$ \\
\hline IIIA & $2.47(1)$ & $7.25(1)$ & $7.03(1)$ & $5.04(1)$ \\
\hline IIIB & $4.76(0)$ & $1.74(1)$ & $1.92(1)$ & $1.48(1)$ \\
\hline IIIC & $2.40(-1)$ & $2.71(0)$ & $3.84(0)$ & $3.05(0)$ \\
\hline
\end{tabular}

${ }^{a}$ See experimental program plan in Appendix A for description of configurations.

${ }^{b}$ Read: $6.75 \times 10^{2}$. 
Table 18. Bonner ball measurements on centerline at $150 \mathrm{~cm}$ behind mockups (Items IA, IIA-D, IIIA-C)

\begin{tabular}{|c|c|c|c|c|c|c|c|c|}
\hline \multirow[b]{3}{*}{ Configuration $^{a}$} & \multicolumn{8}{|c|}{ Bonner ball count rates $\left(s^{-1} W^{-1}\right)$} \\
\hline & \multicolumn{2}{|c|}{ 3-in-Diam Ball } & \multicolumn{2}{|c|}{ 5-in-Diam Ball } & \multicolumn{2}{|c|}{ 8-in-Diam Ball } & \multicolumn{2}{|c|}{ 10-in-Diam Ball } \\
\hline & Foreground $^{b}$ & Background $^{c}$ & Foreground & Background & Foreground & Background & Foreground & Background \\
\hline IA & $1.29(2)^{d}$ & $2.87(1)$ & $5.81(2)$ & $7.14(1)$ & $3.94(2)$ & $3.53(1)$ & $2.01(2)$ & $1.65(1)$ \\
\hline IIA & $4.43(1)$ & $6.97(0)$ & $1.65(2)$ & $1.60(1)$ & $1.11(2)$ & $7.61(0)$ & $5.36(1)$ & $3.52(0)$ \\
\hline IIB & $8.62(0)$ & $7.21(-1)$ & $1.70(1)$ & $1.26(0)$ & $9.78(0)$ & $5.67(-1)$ & $4.81(0)$ & $2.66(-1)$ \\
\hline IIC & $4.02(0)$ & $4.33(-1)$ & $8.69(0)$ & $7.84(-1)$ & $4.88(0)$ & $3.66(-1)$ & $2.44(0)$ & $1.77(-1)$ \\
\hline IID & $4.85(-2)$ & $1.10(-2)$ & $3.22(-1)$ & $3.34(-2)$ & $3.21(-1)$ & $2.15(-2)$ & $1.95(-1)$ & $1.14(-2)$ \\
\hline IIIA & $4.51(0)$ & $4.84(-1)$ & $1.35(1)$ & $1.11(0)$ & $1.36(1)$ & $7.31(-1)$ & $9.78(0)$ & $4.43(-1)$ \\
\hline IIIB & $9.60(-1)$ & $1.46(-1)$ & $3.43(0)$ & $3.58(-1)$ & $3.97(0)$ & $2.48(-1)$ & $3.10(0)$ & $1.59(-1)$ \\
\hline IIIC & $5.22(-2)$ & $1.55(-2)$ & $4.99(-1)$ & $5.57(-2)$ & $7.14(-1)$ & $4.55(-2)$ & $5.70(-1)$ & $3.11(-2)$ \\
\hline
\end{tabular}

a See experimental program plan in Appendix A for description of experiments.

${ }^{b}$ Count rates without shadow shield between detector and configuration.

${ }^{c}$ Count rates with shadow shield between detector and configuration.

${ }^{d}$ Read: $1.29 \times 10^{2}$. 
Table 19. Spectrum of high-energy neutrons ( $>0.8 \mathrm{MeV}$ ) on centerline at $25 \mathrm{~cm}$ behind the lead slabs (Item IIB): Run 7932

\begin{tabular}{|c|c|c|c|c|c|}
\hline & \multicolumn{2}{|c|}{ Flux (neutrons $\mathrm{cm}^{-2} \mathrm{MeV}^{-1} \mathrm{~kW}^{-1} \mathrm{~s}^{-1}$ ) } & \multirow[b]{2}{*}{$\begin{array}{c}\text { Neutron } \\
\text { Energy } \\
(\mathrm{MeV})\end{array}$} & \multicolumn{2}{|c|}{ Flux (neutrons $\mathrm{cm}^{-2} \mathrm{MeV}^{-1} \mathrm{~kW}^{-1} \mathrm{~s}^{-1}$ ) } \\
\hline $\begin{array}{l}\text { Neutron } \\
\text { Energy } \\
(\mathrm{MeV})\end{array}$ & $\begin{array}{l}\text { Lower } \\
\text { Limit }\end{array}$ & $\begin{array}{l}\text { Upper } \\
\text { Limit }\end{array}$ & & $\begin{array}{l}\text { Lower } \\
\text { Limit }\end{array}$ & $\begin{array}{l}\text { Upper } \\
\text { Limit }\end{array}$ \\
\hline \multirow{2}{*}{$\begin{array}{l}8.11 E-01 \\
9.07 E-01\end{array}$} & $3.82 E+03$ & $3.94 E+03$ & $5.94 E+00$ & $5.65 \mathrm{E}+01$ & $6.22 \mathrm{E}+01$ \\
\hline & $4.05 E+03$ & $4.10 \mathrm{E}+03$ & $6.25 E+00$ & $4.75 E+01$ & $5.42 E+01$ \\
\hline $1.01 \mathrm{E}+00$ & $3.65 E+03$ & $3.69 E+03$ & $6.55 E+00$ & $3.99 E+01$ & $4.56 \mathrm{E}+01$ \\
\hline $1.11 \mathrm{E}+00$ & $3.13 E+03$ & $3.17 \mathrm{E}+03$ & $6.84 \mathrm{E}+00$ & $3.60 \mathrm{E}+01$ & $4.01 \mathrm{E}+01$ \\
\hline $1.20 \mathrm{E}+00$ & $2.67 E+03$ & $2.70 \mathrm{E}+03$ & $7.24 \mathrm{E}+00$ & $3.16 E+01$ & $3.52 \mathrm{E}+01$ \\
\hline $1.31 E+00$ & $2.25 E+03$ & $2.29 E+03$ & $7.74 E+00$ & $2.45 E+01$ & $2.87 \mathrm{E}+01$ \\
\hline $1.41 \mathrm{E}+00$ & $1.94 \bar{E}+03$ & $1.97 \mathrm{E}+03$ & $8.24 E+00$ & $1.82 \mathrm{E}+01$ & $2.24 \mathrm{E}+01$ \\
\hline \multirow{2}{*}{$\begin{array}{l}1.51 E+00 \\
1.61 E+00\end{array}$} & $1.72 E+03$ & $1.74 E+03$ & $8.76 \mathrm{E}+00$ & $1.42 E+01$ & $1.65 E+01$ \\
\hline & $1.53 E+03$ & $1.55 E+03$ & $9.26 \mathrm{E}+00$ & $1.20 \mathrm{E}+01$ & $1.41 E+01$ \\
\hline $1.71 \mathrm{E}+00$ & $1.36 \mathrm{E}+03$ & $1.38 \mathrm{E}+03$ & $9.74 \mathrm{E}+00$ & $1.05 \mathrm{E}+01$ & $1.23 \mathrm{E}+01$ \\
\hline $1.81 \mathrm{E}+00$ & $1.19 E+03$ & $1.22 E+03$ & $1.03 E+01$ & $8.09 E+00$ & $9.70 \mathrm{E}+00$ \\
\hline $1.93 E+00$ & $1.03 E+03$ & $1.05 E+03$ & $1.08 E+01$ & $5.82 \mathrm{E}+00$ & $7.24 \mathrm{E}+00$ \\
\hline $2.10 \mathrm{E}+00$ & $8.25 E+02$ & $8.44 \mathrm{E}+02$ & $1.12 \mathrm{E}+01$ & $4.79 E+00$ & $5.98 \mathrm{E}+00$ \\
\hline \multirow{2}{*}{$\begin{array}{l}2.30 E+00 \\
2.50 E+00\end{array}$} & $6.49 E+02$ & $6.66 \mathrm{E}+02$ & $1.18 \mathrm{E}+01$ & $4.04 E+00$ & $5.02 E+00$ \\
\hline & $5.17 \mathrm{E}+02$ & $5.31 E+02$ & $1.24 \mathrm{E}+01$ & $2.58 \mathrm{E}+00$ & $3.54 \mathrm{E}+00$ \\
\hline $2.70 E+00$ & 4.05E +02 & $4.19 \mathrm{E}+02$ & $1.32 \mathrm{E}+01$ & $1.17 \mathrm{E}+00$ & $1.90 \mathrm{E}+00$ \\
\hline $2.90 \mathrm{E}+00$ & $3.34 \mathrm{E}+02$ & $3.47 E+02$ & $1.40 \mathrm{E}+01$ & $8.54 \mathrm{E}-01$ & $1.52 \mathrm{E}+00$ \\
\hline $3.10 \mathrm{E}+00$ & $2.69 E+02$ & $2.83 E+02$ & $1.48 \mathrm{E}+01$ & $7.98 \mathrm{E}-01$ & $1.32 \mathrm{E}+00$ \\
\hline $3.30 \mathrm{E}+00$ & $2.08 \mathrm{E}+02$ & $2.19 E+02$ & $1.56 \mathrm{E}+01$ & $6.03 E-01$ & $1.00 \mathrm{E}+00$ \\
\hline $3.50 \mathrm{E}+00$ & $1.65 \mathrm{E}+02$ & $1.77 \mathrm{E}+02$ & $1.65 \mathrm{E}+01$ & $2.41 \mathrm{E}-01$ & $5.45 E-01$ \\
\hline \multirow{2}{*}{$\begin{array}{l}3.71 E+00 \\
3.91 E+00\end{array}$} & $1.40 \mathrm{E}+02$ & $1.50 \mathrm{E}+02$ & $1.75 E+01$ & $-9.22 E-02$ & $1.43 E-01$ \\
\hline & $1.25 \mathrm{E}+02$ & $1.34 \mathrm{E}+02$ & $1.85 \mathrm{E}+01$ & $-8.75 \mathrm{E}-02$ & $9.26 \mathrm{E}-02$ \\
\hline $4.15 \mathrm{E}+00$ & $1.19 E+02$ & $1.27 \mathrm{E}+02$ & $1.95 E+01$ & $-5.94 E-02$ & $1.15 E-01$ \\
\hline $4.45 E+\infty 0$ & $1.16 E+02$ & $1.23 E+02$ & $2.05 E+01$ & $-8.41 \mathrm{E}-02$ & $1.83 E-01$ \\
\hline $4.75 E+00$ & $1.07 \mathrm{E}+02$ & $1.14 \mathrm{E}+02$ & $2.16 E+01$ & $-1.00 \mathrm{E}-01$ & $1.80 \mathrm{E}-01$ \\
\hline $5.04 \bar{E}+00$ & $9.19 E+01$ & $9.79 E+01$ & $2.26 E+01$ & $-1.06 \mathrm{E}-01$ & $8.44 E-02$ \\
\hline $5.34 E+\infty 0$ & $7.52 E+01$ & $8.08 E+01$ & $2.35 E+01$ & $-1.13 E-01$ & $5.05 \mathrm{E}-02$ \\
\hline $5.64 \mathrm{E}+00$ & $6.34 \mathrm{E}+01$ & $6.97 \mathrm{E}+01$ & & & \\
\hline $\begin{array}{c}\mathrm{E1} \\
(\mathrm{MeV})\end{array}$ & $\begin{array}{c}\mathrm{E} 2 \\
(\mathrm{MeV})\end{array}$ & $\begin{array}{r}\text { In } \\
\text { neutrons }\end{array}$ & ${ }^{-2} \mathbf{k W}^{-1} \mathbf{s}^{-1}$ & $\begin{array}{r}\text { Error } \\
\text { neutrons } \mathrm{cm}^{-2}\end{array}$ & \\
\hline 0.811 & 1.000 & 7.5 & +02 & $5.59 \mathrm{E}+$ & \\
\hline 1.000 & 1.200 & 6.3 & +02 & 3.61E + & \\
\hline 1.200 & 1.600 & 8.1 & +02 & $5.98 \mathrm{E}+$ & \\
\hline 1.600 & 2.000 & 4.9 & +02 & $4.36 \mathrm{E}+$ & \\
\hline 2.000 & 3.000 & 5.5 & +02 & 7.73E + & \\
\hline 3.000 & 4.000 & 1.8 & +02 & $5.62 \mathrm{E}+$ & \\
\hline 4.000 & 6.000 & 1.9 & +02 & $6.57 E+$ & \\
\hline 6.000 & 8.000 & 7.5 & +01 & $4.71 \mathrm{E}+$ & \\
\hline 8.000 & 10.000 & 3.0 & +01 & $2.57 \mathrm{E}+$ & \\
\hline 10.000 & 12.000 & 1.2 & +01 & $1.31 \mathrm{E}+$ & \\
\hline 12.000 & 16.000 & 6.1 & $+\infty$ & $1.30 \mathrm{E}+$ & \\
\hline 16.000 & 20.000 & 4.7 & -01 & $4.55 \mathrm{E}-\mathrm{C}$ & \\
\hline 3.000 & 10.000 & 4.8 & +02 & $1.95 \mathrm{E}+$ & \\
\hline 1.500 & 15.000 & 1.7 & +03 & $3.53 \mathrm{E}+$ & \\
\hline 3.000 & 12.000 & 4.9 & +02 & $2.08 \mathrm{E}+$ & \\
\hline
\end{tabular}


Table 20. Neutron spectrum ( $50 \mathrm{keV}$ to $1.4 \mathrm{MeV}$ ) on centerline at $25 \mathrm{~cm}$ behind the lead slabs (Item IIB) Runs 1603.C, 1603.B, 1603.A

\begin{tabular}{|c|c|c|c|c|}
\hline $\mathbf{N}$ & Energ & ndary & $\begin{array}{c}\text { Flux } \\
\text { (neutrons } \mathrm{cm}^{-2} \mathrm{MeV}^{-1} \mathrm{~kW}^{-1} \mathrm{~s}^{-1} \text { ) }\end{array}$ & $\begin{array}{c}\text { Error } \\
(\%)\end{array}$ \\
\hline \multicolumn{5}{|c|}{ RUN 1603.C } \\
\hline 1 & 0.0448 & 0.0536 & $7.14 \mathrm{E}+04$ & 2.05 \\
\hline 2 & 0.0536 & 0.0624 & $4.68 \mathrm{E}+04$ & 3.48 \\
\hline 3 & 0.0624 & 0.0747 & $3.75 E+04$ & 3.38 \\
\hline 4 & 0.0747 & 0.0870 & $3.47 \mathrm{E}+04$ & 4.18 \\
\hline 5 & 0.0870 & 0.1028 & $3.11 E+04$ & 3.92 \\
\hline 6 & 0.1028 & 0.1204 & $2.68 \mathrm{E}+04$ & 4.61 \\
\hline 7 & 0.1204 & 0.1415 & $2.56 \mathrm{E}+04$ & 4.41 \\
\hline 8 & 0.1415 & 0.1679 & $2.44 \mathrm{E}+04$ & 3.99 \\
\hline 9 & 0.1679 & 0.1977 & $2.12 E+04$ & 4.48 \\
\hline \multicolumn{5}{|c|}{ RUN 1603.B } \\
\hline 1 & 0.1459 & 0.1653 & $2.34 \mathrm{E}+04$ & 2.32 \\
\hline 2 & 0.1653 & 0.1977 & $2.14 \mathrm{E}+04$ & 1.73 \\
\hline 3 & 0.1977 & 0.2302 & $1.90 E+04$ & 2.23 \\
\hline 4 & 0.2302 & 0.2755 & $1.75 E+04$ & 1.91 \\
\hline 5 & 0.2755 & 0.3209 & $1.69 E+04$ & 2.26 \\
\hline 6 & 0.3209 & 0.3793 & $1.45 \mathrm{E}+04$ & 2.23 \\
\hline 7 & 0.3793 & 0.4441 & $1.15 E+04$ & 2.81 \\
\hline 8 & 0.4441 & 0.5284 & $1.08 E+04$ & 2.40 \\
\hline \multicolumn{5}{|c|}{$\underline{\text { RUN 1603.A }}$} \\
\hline 1 & 0.3759 & 0.4521 & $1.11 E+04$ & 1.24 \\
\hline 2 & 0.4521 & 0.5284 & $1.06 \mathrm{E}+04$ & 1.45 \\
\hline 3 & 0.5284 & 0.6156 & $9.82 E+03$ & 1.43 \\
\hline 4 & 0.6156 & 0.7245 & $7.14 \mathrm{E}+03$ & 1.61 \\
\hline 5 & 0.7245 & 0.8553 & $5.10 E+03$ & 1.95 \\
\hline 6 & 0.8553 & 1.0078 & $3.70 \mathrm{E}+03$ & 2.41 \\
\hline 7 & 1.0078 & 1.1821 & $2.92 \mathrm{E}+03$ & 2.78 \\
\hline 8 & 1.1821 & 1.4000 & $2.48 E+03$ & 2.57 \\
\hline
\end{tabular}


Table 21. 3-inch Bonner ball traverses through the horizontal midplane at $30 \mathrm{~cm}$ behind a series of configurations (Items IIB-D, IIIB-C)

\begin{tabular}{|c|c|c|c|c|c|}
\hline \multirow{2}{*}{$\begin{array}{c}\text { Distance from } \\
\text { Centerline } \\
(\mathrm{cm})\end{array}$} & \multicolumn{5}{|c|}{ Bonner ball count rates $\left(\mathrm{s}^{-1} \mathrm{~W}^{-1}\right)$} \\
\hline & $\underline{\text { Item IIB }}^{a}$ & Item IIC & Item IID & Item IIIB & Item IIIC \\
\hline $100 \mathrm{~S}$ & & $5.14(0)^{b}$ & $5.30(-2)$ & $7.53(-1)$ & \\
\hline 96.4 & & & & & $6.57(-2)$ \\
\hline 90 & & $7.26(0)$ & $7.09(-2)$ & $1.01(0)$ & $7.59(-2)$ \\
\hline 80 & $1.30(1)$ & $9.93(0)$ & $9.85(-2)$ & $1.47(0)$ & $9.45(-2)$ \\
\hline 70 & $1.72(1)$ & $1.22(1)$ & $1.21(-1)$ & $1.99(0)$ & $1.16(-1)$ \\
\hline 60 & $2.28(1)$ & $1.40(1)$ & $1.44(-1)$ & $2.82(0)$ & $1.40(-1)$ \\
\hline 50 & $3.08(1)$ & $1.54(1)$ & $1.63(-1)$ & $3.25(0)$ & $1.63(-1)$ \\
\hline 40 & $3.76(1)$ & $1.70(1)$ & $1.79(-1)$ & $3.86(0)$ & $1.89(-1)$ \\
\hline 30 & $4.23(1)$ & $1.87(1)$ & $2.00(-1)$ & $4.36(0)$ & $2.10(-1)$ \\
\hline 20 & $4.65(1)$ & $1.97(1)$ & $2.10(-1)$ & $4.73(0)$ & $2.26(-1)$ \\
\hline 10 & $4.89(1)$ & $2.06(1)$ & $2.17(-1)$ & $5.05(0)$ & $2.36(-1)$ \\
\hline 0 & $4.89(1)$ & $2.06(1)$ & $2.19(-1)$ & $5.07(0)$ & $2.39(-1)$ \\
\hline 10 & $4.77(1)$ & $2.00(1)$ & $2.19(-1)$ & $4.92(0)$ & $2.33(-1)$ \\
\hline 20 & $4.43(1)$ & $1.90(1)$ & $2.10(-1)$ & $4.61(0)$ & $2.23(-1)$ \\
\hline 30 & $3.95(1)$ & $1.77(1)$ & $1.95(-1)$ & $4.24(0)$ & $2.05(-1)$ \\
\hline 40 & $3.46(1)$ & $1.59(1)$ & $1.80(-1)$ & $3.64(0)$ & $1.82(-1)$ \\
\hline 50 & 2.77 (1) & $1.39(1)$ & $1.58(-1)$ & $3.09(0)$ & $1.58(-1)$ \\
\hline 60 & $2.11(1)$ & $1.22(1)$ & $1.44(-1)$ & $2.60(0)$ & $1.33(-1)$ \\
\hline 65 & $1.80(1)$ & & & & \\
\hline 70 & & $1.01(1)$ & $1.21(-1)$ & $1.88(0)$ & $1.10(-1)$ \\
\hline 75 & & & $1.11(-1)$ & $1.62(0)$ & \\
\hline $80 \mathrm{~N}$ & & $7.64(0)$ & & & $8.81(-2)$ \\
\hline
\end{tabular}

aSee experimental program plan in Appendix $A$ for description of configurations.

${ }^{b}$ Read: $5.14 \times 10^{\circ}$. 
Table 22. 5-inch Bonner ball traverses through the horizontal midplane at $30 \mathrm{~cm}$ behind a series of configurations

(Items IIB-D, IIIB-C)

\begin{tabular}{|c|c|c|c|c|c|}
\hline \multirow{2}{*}{$\begin{array}{l}\text { Distance from } \\
\text { Centerline } \\
\text { (cm) } \\
\end{array}$} & \multicolumn{5}{|c|}{ Bonner ball count rates $\left(\mathrm{s}^{-1} \mathrm{~W}^{-1}\right)$} \\
\hline & $\underline{\text { Item IIB }}^{a}$ & Item IIC & Item IID & Item IIIB & $\underline{\text { Item IIIC }}$ \\
\hline $100 \mathrm{~S}$ & & $7.04(0)^{b}$ & $2.96(-1)$ & $2.22(0)$ & \\
\hline 92.9 & & & & & $5.53(-1)$ \\
\hline 90 & & $1.08(1)$ & $4.35(-1)$ & $3.11(0)$ & $6.00(-1)$ \\
\hline 80 & $2.52(1)$ & $1.71(1)$ & $6.31(-1)$ & $4.66(0)$ & $8.39(-1)$ \\
\hline 70 & $3.21(1)$ & $2.48(1)$ & $8.11(-1)$ & $6.48(0)$ & $1.11(0)$ \\
\hline 60 & $4.34(1)$ & $3.06(1)$ & $9.81(-1)$ & $9.13(0)$ & $1.42(0)$ \\
\hline 50 & $5.73(1)$ & $3.35(1)$ & $1.15(0)$ & $1.11(1)$ & $1.72(0)$ \\
\hline 40 & $6.96(1)$ & $3.68(1)$ & $1.31(0)$ & $1.33(1)$ & $2.04(0)$ \\
\hline 30 & $8.04(1)$ & $4.05(1)$ & $1.45(0)$ & $1.52(1)$ & $2.34(0)$ \\
\hline 20 & $8.82(1)$ & $4.29(1)$ & $1.54(0)$ & $1.67(1)$ & $2.53(0)$ \\
\hline 10 & $9.08(1)$ & $4.42(1)$ & $1.63(0)$ & $1.78(1)$ & $2.65(0)$ \\
\hline 0 & $9.30(1)$ & $4.48(1)$ & $1.61(0)$ & $1.79(1)$ & $2.66(0)$ \\
\hline 10 & $8.96(1)$ & 4.32 (1) & $1.58(0)$ & $1.74(1)$ & $2.60(0)$ \\
\hline 20 & $8.37(1)$ & $4.08(1)$ & $1.51(0)$ & $1.65(1)$ & $2.46(0)$ \\
\hline 30 & $7.33(1)$ & $3.75(1)$ & $1.42(0)$ & $1.48(1)$ & $2.26(0)$ \\
\hline 40 & $6.38(1)$ & $3.35(1)$ & $1.26(0)$ & $1.28(1)$ & $1.97(0)$ \\
\hline 50 & $5.20(1)$ & $2.99(1)$ & $1.12(0)$ & 1.07 (1) & $1.65(0)$ \\
\hline 60 & $3.86(1)$ & $2.65(1)$ & $9.85(-1)$ & $8.60(0)$ & $1.33(0)$ \\
\hline 65 & 3.31 (1) & & & & \\
\hline 70 & & $2.23(1)$ & $7.98(-1)$ & $6.18(0)$ & $1.02(0)$ \\
\hline 75 & & & $6.97(-1)$ & $5.21(0)$ & \\
\hline $80 \mathrm{~N}$ & & $1.64(1)$ & & & $7.66(-1)$ \\
\hline
\end{tabular}

asee experimental program plan in Appendix A for description of configurations.

${ }^{b}$ Read: $7.04 \times 10^{\circ}$. 
Table 23. 8-inch Bonner ball traverses through the horizontal midplane at $30 \mathrm{~cm}$ behind a series of configurations (Items IIB-D, IIIB-C)

\begin{tabular}{|c|c|c|c|c|c|}
\hline \multirow{2}{*}{$\begin{array}{c}\text { Distance from } \\
\text { Centerline } \\
(\mathrm{cm}) \\
\end{array}$} & \multicolumn{5}{|c|}{ Bonner ball count rates $\left(\mathrm{s}^{-1} \mathrm{~W}^{-1}\right)$} \\
\hline & $\underline{\text { Item IIB }}^{a}$ & Item IIC & Item IID & Item IIIB & Item IIIC \\
\hline $100 \mathrm{~s}$ & & $3.95(0)^{b}$ & $2.61(-1)$ & $1.94(0)$ & \\
\hline 90 & & $6.15(0)$ & $3.76(-1)$ & $2.90(0)$ & \\
\hline 80 & $1.36(1)$ & $9.73(0)$ & $5.69(-1)$ & $4.51(0)$ & $1.04(0)$ \\
\hline 70 & $1.74(1)$ & $1.36(1)$ & $7.43(-1)$ & $6.71(0)$ & $1.43(0)$ \\
\hline 60 & $2.43(1)$ & $1.67(1)$ & $9.13(-1)$ & $9.31(0)$ & $1.87(0)$ \\
\hline 50 & $3.21(1)$ & $1.83(1)$ & $1.08(0)$ & $1.19(1)$ & $2.34(0)$ \\
\hline 40 & $3.81(1)$ & $2.02(1)$ & $1.24(0)$ & $1.43(1)$ & $2.83(0)$ \\
\hline 30 & $4.39(1)$ & $2.16(1)$ & $1.37(0)$ & $1.64(1)$ & $3.25(0)$ \\
\hline 20 & $4.87(1)$ & $2.37(1)$ & $1.52(0)$ & $1.82(1)$ & $3.56(0)$ \\
\hline 10 & $4.99(1)$ & $2.42(1)$ & $1.58(0)$ & $1.92(1)$ & $3.78(0)$ \\
\hline 0 & $5.13(1)$ & $2.44(1)$ & $1.59(0)$ & $1.95(1)$ & $3.85(0)$ \\
\hline 10 & $4.85(1)$ & $2.34(1)$ & $1.58(0)$ & $1.89(1)$ & $3.78(0)$ \\
\hline 20 & 4.69 (1) & $2.20(1)$ & $1.49(0)$ & $1.78(1)$ & $3.63(0)$ \\
\hline 30 & $4.10(1)$ & $2.03(1)$ & $1.35(0)$ & $1.59(1)$ & $3.32(0)$ \\
\hline 40 & $3.58(1)$ & $1.80(1)$ & $1.23(0)$ & $1.37(1)$ & $2.90(0)$ \\
\hline 50 & $2.88(1)$ & $1.59(1)$ & $1.06(0)$ & $1.12(1)$ & $2.47(0)$ \\
\hline 60 & $2.10(1)$ & $1.43(1)$ & $9.08(-1)$ & $8.75(0)$ & $1.99(0)$ \\
\hline 70 & $1.43(1)$ & $1.15(1)$ & $7.40(-1)$ & $6.20(0)$ & $1.52(0)$ \\
\hline 75 & & & $6.41(-1)$ & $5.09(0)$ & \\
\hline $80 \mathrm{~N}$ & & $8.44(0)$ & & & $1.10(0)$ \\
\hline
\end{tabular}

aSee experimental program plan in Appendix $A$ for description of configurations.

${ }^{b}$ Read: $3.95 \times 10^{0}$. 
Table 24. Spectrum of high-energy neutrons ( $>0.8 \mathrm{MeV}$ ) on centerline at $25 \mathrm{~cm}$ behind the lead slabs (Item IIC): Run 7933

\begin{tabular}{|c|c|c|c|c|c|}
\hline \multirow{2}{*}{$\begin{array}{l}\text { Neutron } \\
\text { Energy } \\
(\mathrm{MeV})\end{array}$} & \multicolumn{2}{|c|}{ Flux (neutrons $\mathrm{cm}^{-2} \mathrm{MeV}^{-1} \mathrm{~kW}^{-1} \mathrm{~s}^{-1}$ ) } & \multirow{2}{*}{$\begin{array}{c}\text { Neutron } \\
\text { Energy } \\
(\mathrm{MeV})\end{array}$} & \multicolumn{2}{|c|}{ Flux (neutrons $\mathrm{cm}^{-2} \mathrm{MeV}^{-1} \mathrm{~kW}^{-1} \mathrm{~s}^{-1}$ ) } \\
\hline & $\begin{array}{l}\text { Lower } \\
\text { Limit }\end{array}$ & $\begin{array}{l}\text { Upper } \\
\text { Limit }\end{array}$ & & $\begin{array}{l}\text { Lower } \\
\text { Limit }\end{array}$ & $\begin{array}{l}\text { Upper } \\
\text { Limit }\end{array}$ \\
\hline $8.11 E-01$ & $2.55 \mathrm{E}+03$ & $2.62 E+03$ & $5.94 E+\infty 0$ & $3.35 \mathrm{E}+01$ & $3.69 E+01$ \\
\hline $9.07 \mathrm{E}-01$ & $2.68 \mathrm{E}+03$ & $2.71 E+03$ & $6.25 \mathrm{E}+00$ & $2.86 \mathrm{E}+01$ & $3.26 \mathrm{E}+01$ \\
\hline $1.01 \mathrm{E}+00$ & $2.38 \mathrm{E}+03$ & $2.40 \mathrm{E}+03$ & $6.55 \mathrm{E}+00$ & $2.46 \mathrm{E}+01$ & $2.79 \mathrm{E}+01$ \\
\hline $1.11 E+00$ & $2.02 E+03$ & $2.05 E+03$ & $6.84 \mathrm{E}+00$ & $2.14 \mathrm{E}+01$ & $2.38 \mathrm{E}+01$ \\
\hline $1.20 E+00$ & $1.72 \mathrm{E}+03$ & $1.74 \mathrm{E}+03$ & $7.24 E+00$ & $1.75 \mathrm{E}+01$ & $1.95 \mathrm{E}+01$ \\
\hline $1.31 E+00$ & $1.46 \mathrm{E}+03$ & $1.47 E+03$ & $7.74 \mathrm{E}+00$ & $1.38 \mathrm{E}+01$ & $1.62 \mathrm{E}+01$ \\
\hline $1.41 E+00$ & $1.25 \mathrm{E}+03$ & $1.27 \mathrm{E}+03$ & $8.24 E+00$ & $1.12 \mathrm{E}+01$ & $1.37 \mathrm{E}+01$ \\
\hline $1.51 \mathrm{E}+00$ & $1.09 E+03$ & $1.11 E+03$ & $8.76 \mathrm{E}+00$ & $9.14 \mathrm{E}+00$ & $1.05 E+01$ \\
\hline $1.61 E+00$ & $9.58 \mathrm{E}+02$ & $9.73 E+02$ & $9.26 \mathrm{E}+00$ & $6.85 \mathrm{E}+00$ & $8.05 E+00$ \\
\hline $1.71 E+00$ & $8.37 \mathrm{E}+02$ & $8.50 \mathrm{E}+02$ & $9.74 \mathrm{E}+00$ & $5.44 \bar{E}+00$ & $6.46 \mathrm{E}+00$ \\
\hline $1.81 \mathrm{E}+00$ & $7.25 \mathrm{E}+02$ & $7.38 \mathrm{E}+02$ & $1.03 E+01$ & $4.63 \mathrm{E}+\infty 0$ & $5.56 \mathrm{E}+00$ \\
\hline $1.93 E+00$ & $6.11 E+02$ & $6.23 E+02$ & $1.08 \mathrm{E}+01$ & $3.71 \mathrm{E}+\infty 0$ & $4.55 E+00$ \\
\hline $2.10 \mathrm{E}+00$ & $4.89 E+02$ & $5.00 \mathrm{E}+02$ & $1.12 E+01$ & $3.01 \mathrm{E}+\infty 0$ & $3.70 \mathrm{E}+00$ \\
\hline $2.30 \mathrm{E}+00$ & $3.83 \mathrm{E}+02$ & $3.93 \mathrm{E}+02$ & $1.18 \mathrm{E}+01$ & $2.62 \mathrm{E}+00$ & $3.18 \mathrm{E}+00$ \\
\hline $2.50 E+00$ & $2.95 \mathrm{E}+02$ & $3.03 E+02$ & $1.24 \mathrm{E}+01$ & $1.79 E+\infty$ & $2.34 \mathrm{E}+00$ \\
\hline $2.70 \mathrm{E}+00$ & $2.28 \mathrm{E}+02$ & $2.35 \mathrm{E}+02$ & $1.32 \mathrm{E}+01$ & $8.04 \mathrm{E}-01$ & $1.18 \mathrm{E}+00$ \\
\hline $2.90 \mathrm{E}+00$ & $1.79 \mathrm{E}+02$ & $1.87 \mathrm{E}+02$ & $1.40 \mathrm{E}+01$ & $3.82 E-01$ & $7.46 \mathrm{E}-01$ \\
\hline $3.10 \mathrm{E}+00$ & $1.41 E+02$ & $1.49 E+02$ & $1.48 \mathrm{E}+01$ & $2.87 \mathrm{E}-01$ & $5.34 \mathrm{E}-01$ \\
\hline $3.30 \mathrm{E}+00$ & $1.16 \mathrm{E}+02$ & $1.22 \mathrm{E}+02$ & $1.56 E+01$ & $2.28 \mathrm{E}-01$ & $4.80 \mathrm{E}-01$ \\
\hline $3.50 \mathrm{E}+00$ & $9.78 \mathrm{E}+01$ & $1.05 \mathrm{E}+02$ & $1.65 E+01$ & $4.21 E-02$ & $2.21 \mathrm{E}-01$ \\
\hline $3.71 E+\infty 0$ & $8.46 \mathrm{E}+01$ & $9.03 E+01$ & $1.75 \mathrm{E}+01$ & $-7.18 \mathrm{E}-02$ & $9.92 \mathrm{E}-02$ \\
\hline $3.91 E+00$ & $7.68 \mathrm{E}+01$ & $8.19 E+01$ & $1.85 \mathrm{E}+01$ & $-9.24 E-02$ & $4.70 \mathrm{E}-02$ \\
\hline $4.15 \mathrm{E}+00$ & $7.14 \mathrm{E}+01$ & $7.62 \mathrm{E}+01$ & $1.95 E+01$ & $-1.05 E-01$ & $3.11 \mathrm{E}-02$ \\
\hline $4.45 E+00$ & $6.57 \mathrm{E}+01$ & $6.98 \mathrm{E}+01$ & $2.05 E+01$ & $-1.06 E-01$ & $9.54 \mathrm{E}-02$ \\
\hline $4.75 E+00$ & $6.01 \mathrm{E}+01$ & $6.39 E+01$ & $2.16 \mathrm{E}+01$ & $-9.36 E-02$ & $1.17 \mathrm{E}-01$ \\
\hline $5.04 \mathrm{E}+00$ & $5.25 E+01$ & $5.60 \mathrm{E}+01$ & $2.26 \mathrm{E}+01$ & $-7.39 E-02$ & $7.90 \mathrm{E}-02$ \\
\hline $5.34 E+\infty 0$ & $4.37 \mathrm{E}+01$ & $4.70 \mathrm{E}+01$ & $2.35 E+01$ & $-6.96 E-02$ & $5.66 \mathrm{E}-02$ \\
\hline $5.64 \mathrm{E}+00$ & $3.76 \mathrm{E}+01$ & $4.13 E+01$ & & & \\
\hline
\end{tabular}

\begin{tabular}{cccc}
$\begin{array}{c}\mathrm{E} 1 \\
(\mathrm{MeV})\end{array}$ & $\begin{array}{c}\mathrm{E} 2 \\
(\mathrm{MeV})\end{array}$ & $\begin{array}{c}\text { Integral } \\
\text { neutrons } \mathrm{cm}^{-2} \mathrm{~kW}^{-1} \mathrm{~s}^{-1}\end{array}$ & $\begin{array}{c}\text { Error } \\
\text { neutrons } \mathrm{cm}^{-2} \mathrm{~kW}^{-1} \mathrm{~s}^{-1}\end{array}$ \\
\hline 0.811 & 1.000 & $4.96 \mathrm{E}+02$ & $3.33 \mathrm{E}+00$ \\
1.000 & 1.200 & $4.13 \mathrm{E}+02$ & $2.16 \mathrm{E}+00$ \\
1.200 & 1.600 & $5.23 \mathrm{E}+02$ & $3.44 \mathrm{E}+00$ \\
1.600 & 2.000 & $3.01 \mathrm{E}+02$ & $2.54 \mathrm{E}+00$ \\
2.000 & 3.000 & $3.19 \mathrm{E}+02$ & $4.48 \mathrm{E}+00$ \\
3.000 & 4.000 & $1.07 \mathrm{E}+02$ & $3.24 \mathrm{E}+00$ \\
4.000 & 6.000 & $1.10 \mathrm{E}+02$ & $3.83 \mathrm{E}+00$ \\
6.000 & 8.000 & $4.39 \mathrm{E}+01$ & $2.72 \mathrm{E}+00$ \\
8.000 & 10.000 & $1.79 \mathrm{E}+01$ & $1.47 \mathrm{E}+00$ \\
10.000 & 12.000 & $7.74 \mathrm{E}+00$ & $7.60 \mathrm{E}-01$ \\
12.000 & 16.000 & $3.50 \mathrm{E}+00$ & $7.05 \mathrm{E}-01$ \\
16.000 & 20.000 & $1.08 \mathrm{E}-01$ & $3.20 \mathrm{E}-01$ \\
3.000 & 10.000 & $2.78 \mathrm{E}+02$ & $1.13 \mathrm{E}+01$ \\
1.500 & 15.000 & $1.01 \mathrm{E}+03$ & $2.05 \mathrm{E}+01$ \\
3.000 & 12.000 & $2.86 \mathrm{E}+02$ & $1.21 \mathrm{E}+01$ \\
\hline
\end{tabular}


Table 25. Neutron spectrum ( $50 \mathrm{keV}$ to $1.4 \mathrm{MeV}$ ) on centerline at $25 \mathrm{~cm}$ behind the lead slabs (Item IIC) Runs 1604.C, 1604.B, 1604.A

\begin{tabular}{|c|c|c|c|c|}
\hline $\mathrm{N}$ & Energ & ndary & $\begin{array}{c}\text { Flux } \\
\text { (neutrons } \mathrm{cm}^{-2} \mathrm{MeV}^{-1} \mathrm{~kW}^{-1} \mathrm{~s}^{-1} \text { ) }\end{array}$ & $\begin{array}{l}\text { Error } \\
(\%)\end{array}$ \\
\hline \multicolumn{5}{|c|}{$\underline{\text { RUN } 1604 . C}$} \\
\hline 1 & 0.0448 & 0.0536 & $3.76 \mathrm{E}+04$ & 2.13 \\
\hline 2 & 0.0536 & 0.0624 & $2.90 \mathrm{E}+04$ & 3.09 \\
\hline 3 & 0.0624 & 0.0730 & $2.43 \mathrm{E}+04$ & 3.40 \\
\hline 4 & 0.0730 & 0.0870 & $2.24 \mathrm{E}+04$ & 3.01 \\
\hline 5 & 0.0870 & 0.1011 & $1.92 E+04$ & 4.00 \\
\hline 6 & 0.1011 & 0.1187 & $1.67 \mathrm{E}+04$ & 4.00 \\
\hline 7 & 0.1187 & 0.1398 & $1.74 \mathrm{E}+04$ & 3.50 \\
\hline 8 & 0.1398 & 0.1662 & $1.46 \mathrm{E}+04$ & 3.57 \\
\hline \multicolumn{5}{|c|}{$\underline{\text { RUN 1604.B }}$} \\
\hline 1 & 0.1205 & 0.1466 & $1.74 \mathrm{E}+04$ & 1.32 \\
\hline 2 & 0.1466 & 0.1662 & $1.49 \mathrm{E}+04$ & 2.30 \\
\hline 3 & 0.1662 & 0.1987 & $1.38 \mathrm{E}+04$ & 1.69 \\
\hline 4 & 0.1987 & 0.2313 & $1.22 \mathrm{E}+04$ & 2.19 \\
\hline 5 & 0.2313 & 0.2769 & $1.11 \mathrm{E}+04$ & 1.88 \\
\hline 6 & 0.2769 & 0.3225 & $1.08 \mathrm{E}+04$ & 2.20 \\
\hline 7 & 0.3225 & 0.3812 & $8.94 E+03$ & 2.23 \\
\hline 8 & 0.3812 & 0.4463 & $7.25 E+03$ & 2.74 \\
\hline 9 & 0.4463 & 0.5310 & $7.02 \mathrm{E}+03$ & 2.26 \\
\hline \multicolumn{5}{|c|}{ RUN 1604.A } \\
\hline 1 & 0.3808 & 0.4452 & $6.94 \mathrm{E}+03$ & 1.50 \\
\hline 2 & 0.4452 & 0.5310 & $6.89 \mathrm{E}+03$ & 1.20 \\
\hline 3 & 0.5310 & 0.6169 & $6.21 E+03$ & 1.44 \\
\hline 4 & 0.6169 & 0.7241 & $4.59 \mathrm{E}+03$ & 1.60 \\
\hline 5 & 0.7241 & 0.8529 & $3.45 E+03$ & 1.84 \\
\hline 6 & 0.8529 & 1.0031 & $2.53 E+03$ & 2.24 \\
\hline 7 & 1.0031 & 1.1854 & $2.00 \mathrm{E}+03$ & 2.36 \\
\hline 8 & 1.1854 & 1.4000 & $1.55 \mathrm{E}+03$ & 2.58 \\
\hline
\end{tabular}


Table 26. Spectrum of high-energy neutrons $(>0.8 \mathrm{MeV}$ ) on centerline at $25 \mathrm{~cm}$ behind the lead slabs (Item IID): Run 7934

\begin{tabular}{|c|c|c|c|c|c|}
\hline \multirow{2}{*}{$\begin{array}{c}\text { Neutron } \\
\text { Energy } \\
(\mathrm{MeV})\end{array}$} & \multicolumn{2}{|c|}{ Flux (neutrons $\mathrm{cm}^{-2} \mathrm{MeV}^{-1} \mathrm{~kW}^{-1} \mathrm{~s}^{-1}$ ) } & \multirow{2}{*}{$\begin{array}{c}\text { Neutron } \\
\text { Energy } \\
(\mathrm{MeV})\end{array}$} & \multicolumn{2}{|c|}{ Flux (neutrons $\mathrm{cm}^{-2} \mathrm{MeV}^{-1} \mathrm{~kW}^{-1} \mathrm{~s}^{-1}$ ) } \\
\hline & $\begin{array}{l}\text { Lower } \\
\text { Limit }\end{array}$ & $\begin{array}{l}\text { Upper } \\
\text { Limit }\end{array}$ & & $\begin{array}{l}\text { Lower } \\
\text { Limit }\end{array}$ & $\begin{array}{l}\text { Upper } \\
\text { Limit }\end{array}$ \\
\hline 8.11E -01 & $4.04 E+02$ & $4.14 E+02$ & $5.94 E+00$ & $5.37 \mathrm{E}+00$ & $5.94 \mathrm{E}+00$ \\
\hline 9.07E -01 & $4.40 E+02$ & $4.44 E+02$ & $6.25 E+00$ & $4.74 E+00$ & $5.40 E+00$ \\
\hline $1.01 E+\infty 0$ & $3.77 E+02$ & $3.80 E+02$ & $6.55 \mathrm{E}+00$ & $4.48 E+00$ & $5.02 E+00$ \\
\hline $1.11 E+00$ & $2.82 E+02$ & $2.85 E+02$ & $6.84 \mathrm{E}+00$ & $4.04 E+00$ & $4.45 E+00$ \\
\hline $1.20 \mathrm{E}+00$ & $2.01 E+02$ & $2.04 E+02$ & $7.24 \mathrm{E}+00$ & $3.48 E+00$ & $3.83 E+00$ \\
\hline $1.31 E+00$ & $1.48 \mathrm{E}+02$ & $1.51 E+02$ & $7.74 \mathrm{E}+00$ & $3.07 E+00$ & $3.50 E+00$ \\
\hline $1.41 E+00$ & $1.23 E+02$ & $1.26 \mathrm{E}+02$ & $8.24 \mathrm{E}+00$ & $2.74 E+00$ & $3.19 \mathrm{E}+00$ \\
\hline $1.51 E+\infty 0$ & $1.10 E+02$ & $1.12 \mathrm{E}+02$ & $8.76 \mathrm{E}+00$ & $2.19 E+00$ & $2.42 \mathrm{E}+00$ \\
\hline $1.61 E+00$ & $9.99 \mathrm{E}+01$ & $1.02 \mathrm{E}+02$ & $9.26 \mathrm{E}+00$ & $1.48 \mathrm{E}+00$ & $1.69 E+00$ \\
\hline $1.71 E+00$ & $9.17 \mathrm{E}+01$ & $9.36 \mathrm{E}+01$ & $9.74 \mathrm{E}+00$ & $1.11 E+\infty 0$ & $1.29 E+00$ \\
\hline $1.81 E+\infty 0$ & $8.51 E+01$ & $8.69 E+01$ & $1.03 E+01$ & $1.01 E+00$ & $1.17 \mathrm{E}+00$ \\
\hline $1.93 E+00$ & $7.82 \mathrm{E}+01$ & $7.99 \mathrm{E}+01$ & $1.08 \mathrm{E}+01$ & $9.00 \mathrm{E}-01$ & $1.05 E+00$ \\
\hline $2.10 \mathrm{E}+00$ & $6.80 \mathrm{E}+01$ & $6.97 \mathrm{E}+01$ & $1.12 \mathrm{E}+01$ & $6.54 \mathrm{E}-01$ & $7.75 \mathrm{E}-01$ \\
\hline $2.30 E+00$ & $5.47 E+01$ & $5.62 \mathrm{E}+01$ & $1.18 \mathrm{E}+01$ & $4.63 E-01$ & $5.60 \mathrm{E}-01$ \\
\hline $2.50 \mathrm{E}+00$ & $4.13 E+01$ & $4.25 E+01$ & $1.24 E+01$ & $3.57 E-01$ & $4.50 \mathrm{E}-01$ \\
\hline $2.70 E+00$ & $3.17 E+01$ & $3.29 \mathrm{E}+01$ & $1.32 \mathrm{E}+01$ & $1.91 E-01$ & $2.58 E-01$ \\
\hline $2.90 E+00$ & $2.74 E+01$ & $2.87 E+01$ & $1.40 E+01$ & $8.12 E-02$ & $1.40 \mathrm{E}-01$ \\
\hline $3.10 E+00$ & $2.45 \mathrm{E}+01$ & $2.58 \mathrm{E}+01$ & $1.48 \mathrm{E}+01$ & $7.51 E-02$ & 1.21E -01 \\
\hline $3.30 E+00$ & $2.10 E+01$ & $2.20 \mathrm{E}+01$ & $1.56 E+01$ & $7.99 E-02$ & $1.18 \mathrm{E}-01$ \\
\hline $3.50 \mathrm{E}+00$ & $1.73 E+01$ & $1.85 \mathrm{E}+01$ & $1.65 \mathrm{E}+01$ & $5.11 E-02$ & $8.21 E-02$ \\
\hline $3.71 E+\infty 0$ & $1.53 E+01$ & $1.62 \mathrm{E}+01$ & $1.75 E+01$ & $-4.41 E-03$ & $1.98 \mathrm{E}-02$ \\
\hline $3.91 E+00$ & $1.46 E+01$ & $1.55 E+01$ & $1.85 E+01$ & $-1.84 E-02$ & 4.10E - 04 \\
\hline $4.15 E+00$ & $1.42 \mathrm{E}+01$ & $1.49 \mathrm{E}+01$ & $1.95 E+01$ & $-1.10 \mathrm{E}-02$ & $7.01 E-03$ \\
\hline $4.45 E+00$ & $1.26 \mathrm{E}+01$ & $1.33 E+01$ & $2.05 E+01$ & $-2.33 E-02$ & $4.23 E-03$ \\
\hline $4.75 E+\infty 0$ & $1.02 \mathrm{E}+01$ & $1.09 \mathrm{E}+01$ & $2.16 \mathrm{E}+01$ & $-2.66 \mathrm{E}-02$ & $2.28 \mathrm{E}-03$ \\
\hline $5.04 E+00$ & $8.37 E+00$ & $8.93 E+00$ & $2.26 \mathrm{E}+01$ & $-1.15 E-02$ & $8.16 E-03$ \\
\hline $5.34 E+00$ & $7.39 \mathrm{E}+00$ & $7.92 \mathrm{E}+00$ & $2.35 E+01$ & $-3.88 E-03$ & $1.30 \mathrm{E}-02$ \\
\hline $5.64 \mathrm{E}+00$ & $6.38 \mathrm{E}+00$ & $7.01 E+00$ & & & \\
\hline
\end{tabular}

\begin{tabular}{cccc}
$\begin{array}{c}\mathrm{E} 1 \\
(\mathrm{MeV})\end{array}$ & $\begin{array}{c}\mathrm{E} 2 \\
(\mathrm{MeV})\end{array}$ & $\begin{array}{c}\text { Integral } \\
\text { neutrons } \mathrm{cm}^{-2} \mathrm{~kW}^{-1} \mathrm{~s}^{-1}\end{array}$ & $\begin{array}{c}\text { Error } \\
\text { neutrons } \mathrm{cm}^{-2} \mathrm{~kW}^{-1} \mathrm{~s}^{-1}\end{array}$ \\
\hline 0.811 & 1.000 & $8.06 \mathrm{E}+01$ & $5.09 \mathrm{E}-01$ \\
1.000 & 1.200 & $5.82 \mathrm{E}+01$ & $2.94 \mathrm{E}-01$ \\
1.200 & 1.600 & $5.41 \mathrm{E}+01$ & $4.81 \mathrm{E}-01$ \\
1.600 & 2.000 & $3.49 \mathrm{E}+01$ & $3.64 \mathrm{E}-01$ \\
2.000 & 3.000 & $4.53 \mathrm{E}+01$ & $6.86 \mathrm{E}-01$ \\
3.000 & 4.000 & $1.91 \mathrm{E}+01$ & $5.24 \mathrm{E}-01$ \\
4.000 & 6.000 & $1.95 \mathrm{E}+01$ & $6.21 \mathrm{E}-01$ \\
6.000 & 8.000 & $8.23 \mathrm{E}+00$ & $4.65 \mathrm{E}-01$ \\
8.000 & 10.000 & $4.03 \mathrm{E}+00$ & $2.63 \mathrm{E}-01$ \\
10.000 & 12.000 & $1.65 \mathrm{E}+00$ & $1.31 \mathrm{E}-01$ \\
12.000 & 16.000 & $7.46 \mathrm{E}-01$ & $1.21 \mathrm{E}-01$ \\
16.000 & 20.000 & $6.31 \mathrm{E}-02$ & $4.67 \mathrm{E}-02$ \\
3.000 & 10.000 & $5.08 \mathrm{E}+01$ & $1.88 \mathrm{E}+00$ \\
1.500 & 15.000 & $1.44 \mathrm{E}+02$ & $3.27 \mathrm{E}+00$ \\
3.000 & 12.000 & $5.24 \mathrm{E}+01$ & $2.01 \mathrm{E}+00$ \\
\hline
\end{tabular}


Table 27. Neutron spectrum ( $50 \mathrm{keV}$ to $1.4 \mathrm{MeV}$ ) on centerline at $25 \mathrm{~cm}$ behind the lead slabs (Item IID) Runs 1605.C, 1605.B, 1605.A

\begin{tabular}{|c|c|c|c|c|}
\hline $\mathbf{N}$ & \multicolumn{2}{|c|}{$\begin{array}{l}\text { Energy Boundary } \\
(\mathrm{MeV})\end{array}$} & $\begin{array}{l}\text { Flux } \\
\text { (neutrons } \mathrm{cm}^{-2} \mathrm{MeV}^{-1} \mathrm{~kW}^{-1} \mathrm{~s}^{-1} \text { ) }\end{array}$ & $\begin{array}{l}\text { Error } \\
(\%)\end{array}$ \\
\hline \multicolumn{5}{|c|}{ RUN 1605.C } \\
\hline 1 & 0.0376 & 0.0446 & $1.27 \mathrm{E}+04$ & 0.88 \\
\hline 2 & 0.0446 & 0.0534 & $5.55 \mathrm{E}+03$ & 1.66 \\
\hline 3 & 0.0534 & 0.0621 & $3.18 E+03$ & 3.19 \\
\hline 4 & 0.0621 & 0.0726 & $2.50 \mathrm{E}+03$ & 3.73 \\
\hline 5 & 0.0726 & 0.0866 & $2.39 E+03$ & 3.18 \\
\hline 6 & 0.0866 & 0.1006 & $2.07 E+03$ & 4.18 \\
\hline 7 & 0.1006 & 0.1181 & $1.78 E+03$ & 4.19 \\
\hline 8 & 0.1181 & 0.1392 & $1.71 E+03$ & 3.98 \\
\hline 9 & 0.1392 & 0.1654 & $1.56 \mathrm{E}+03$ & 3.75 \\
\hline \multicolumn{5}{|c|}{$\underline{\text { RUN 1605.B }}$} \\
\hline 1 & 0.1200 & 0.1459 & $1.76 \mathrm{E}+03$ & 1.34 \\
\hline 2 & 0.1459 & 0.1654 & $1.45 E+03$ & 2.41 \\
\hline 3 & 0.1654 & 0.1978 & $1.29 E+03$ & 1.84 \\
\hline 4 & 0.1978 & 0.2303 & $1.09 E+03$ & 2.50 \\
\hline 5 & 0.2303 & 0.2757 & $9.61 E+02$ & 2.25 \\
\hline 6 & 0.2757 & 0.3211 & $9.22 \mathrm{E}+02$ & 2.71 \\
\hline 7 & 0.3211 & 0.3795 & $7.61 E+02$ & 2.81 \\
\hline 8 & 0.3795 & 0.4443 & $6.12 E+02$ & 3.58 \\
\hline 9 & 0.4443 & 0.5222 & $6.69 E+02$ & 3.00 \\
\hline 10 & 0.5222 & 0.6195 & $6.77 E+02$ & 2.51 \\
\hline 11 & 0.6195 & 0.7297 & $5.81 E+02$ & 2.72 \\
\hline \multicolumn{5}{|c|}{$\underline{\text { RUN 1605.A }}$} \\
\hline 1 & 0.5243 & 0.6216 & $6.27 E+02$ & 1.92 \\
\hline 2 & 0.6216 & 0.7297 & $5.53 \mathrm{E}+02$ & 2.11 \\
\hline 3 & 0.7297 & 0.8595 & $5.10 \mathrm{E}+02$ & 1.98 \\
\hline 4 & 0.8595 & 1.0108 & $4.15 E+02$ & 2.10 \\
\hline 5 & 1.0108 & 1.1838 & $2.68 \mathrm{E}+02$ & 2.79 \\
\hline 6 & 1.1838 & 1.4000 & $1.34 \mathrm{E}+02$ & 4.35 \\
\hline
\end{tabular}


Table 28. Spectrum of high-energy neutrons ( $>0.8 \mathrm{MeV}$ ) on centerline at $25 \mathrm{~cm}$ behind the lead slabs (Item IIIA): Run 7935

\begin{tabular}{|c|c|c|c|c|c|}
\hline & \multicolumn{2}{|c|}{ Flux (neutrons $\mathrm{cm}^{-2} \mathrm{MeV}^{-1} \mathrm{~kW}^{-1} \mathrm{~s}^{-1}$ ) } & & \multicolumn{2}{|c|}{ Flux (neutrons $\mathrm{cm}^{-2} \mathrm{MeV}^{-1} \mathrm{~kW}^{-1} \mathrm{~s}^{-1}$ ) } \\
\hline $\begin{array}{c}\text { Neutron } \\
\text { Energy } \\
(\mathrm{MeV})\end{array}$ & $\begin{array}{l}\text { Lower } \\
\text { Limit }\end{array}$ & $\begin{array}{l}\text { Upper } \\
\text { Limit }\end{array}$ & $\begin{array}{c}\text { Neutron } \\
\text { Energy } \\
(\mathrm{MeV})\end{array}$ & $\begin{array}{l}\text { Lower } \\
\text { Limit }\end{array}$ & $\begin{array}{l}\text { Upper } \\
\text { Limit }\end{array}$ \\
\hline $8.11 E-01$ & $8.18 E+03$ & $8.41 E+03$ & $5.94 E+00$ & $4.60 \mathrm{E}+02$ & $4.80 E+02$ \\
\hline $9.07 E-01$ & $9.13 E+03$ & $9.25 E+03$ & $6.25 E+00$ & $3.82 \mathrm{E}+02$ & $4.05 E+02$ \\
\hline $1.01 E+00$ & $8.82 E+03$ & $8.92 E+03$ & $6.55 E+00$ & $3.27 \mathrm{E}+02$ & $3.47 \mathrm{E}+02$ \\
\hline $1.11 E+00$ & $8.27 E+03$ & $8.38 E+03$ & $6.84 E+00$ & $2.80 \mathrm{E}+02$ & $2.94 \mathrm{E}+02$ \\
\hline $1.20 E+00$ & $7.85 E+03$ & $7.95 E+03$ & $7.24 E+\infty 0$ & $2.22 \mathrm{E}+02$ & $2.33 E+02$ \\
\hline $1.31 E+00$ & $7.43 E+03$ & $7.53 E+03$ & $7.74 \mathrm{E}+00$ & $1.68 \mathrm{E}+02$ & $1.82 \mathrm{E}+02$ \\
\hline $1.41 E+00$ & $7.06 \mathrm{E}+03$ & $7.15 E+03$ & $8.24 E+00$ & $1.22 \mathrm{E}+02$ & $1.35 \mathrm{E}+02$ \\
\hline $1.51 E+00$ & $6.72 E+03$ & $6.80 E+03$ & $8.76 \mathrm{E}+00$ & $8.04 \mathrm{E}+01$ & $8.70 E+01$ \\
\hline $1.61 E+00$ & $6.33 E+03$ & $6.41 E+03$ & $9.26 \mathrm{E}+00$ & $5.64 \mathrm{E}+01$ & $6.22 E+01$ \\
\hline $1.71 E+00$ & $5.93 E+03$ & $6.00 E+03$ & $9.74 \mathrm{E}+00$ & $4.49 \mathrm{E}+01$ & $4.94 E+01$ \\
\hline $1.81 E+00$ & $5.57 E+03$ & $5.64 \mathrm{E}+03$ & $1.03 E+01$ & $3.51 \mathrm{E}+01$ & $3.93 E+01$ \\
\hline $1.93 E+00$ & $5.18 \mathrm{E}+03$ & $5.25 E+03$ & $1.08 \mathrm{E}+01$ & $2.54 \mathrm{E}+01$ & $2.91 E+01$ \\
\hline $2.10 \mathrm{E}+00$ & $4.59 E+03$ & $4.66 E+03$ & $1.12 E+01$ & $1.69 \mathrm{E}+01$ & $1.98 \mathrm{E}+01$ \\
\hline $2.30 E+00$ & $4.02 E+03$ & $4.08 E^{-03}$ & $1.18 \mathrm{E}+01$ & $1.10 \mathrm{E}+01$ & $1.33 E+01$ \\
\hline $2.50 E+00$ & $3.49 E+03$ & $3.54 \mathrm{E}+03$ & $1.24 \mathrm{E}+01$ & $7.85 \mathrm{E}+00$ & $1.01 E+01$ \\
\hline $2.70 \mathrm{E}+00$ & $2.90 E+03$ & $2.95 E+03$ & $1.32 E+01$ & $5.39 E+00$ & $6.91 E+00$ \\
\hline $2.90 \mathrm{E}+00$ & $2.45 E+03$ & $2.50 \mathrm{E}+03$ & $1.40 \mathrm{E}+01$ & $2.87 \mathrm{E}+00$ & $4.26 \mathrm{E}+00$ \\
\hline $3.10 E+00$ & $2.05 E+03$ & $2.10 E+03$ & $1.48 \mathrm{E}+01$ & $1.65 E+\infty 0$ & $2.63 E+00$ \\
\hline $3.30 \mathrm{E}+00$ & $1.66 E+03$ & $1.71 E+03$ & $1.56 \mathrm{E}+01$ & $1.24 \mathrm{E}+00$ & $2.09 E+00$ \\
\hline $3.50 E+00$ & $1.40 E+03$ & $1.45 \mathrm{E}+03$ & $1.65 \bar{E}+01$ & $6.22 \mathrm{E}-01$ & $1.22 \mathrm{E}+00$ \\
\hline $3.71 E+00$ & $1.26 E+03$ & $1.29 \mathrm{E}+03$ & $1.75 E+01$ & $-1.63 E-01$ & $2.83 \mathrm{E}-01$ \\
\hline $3.91 E+00$ & $1.14 E+03$ & $1.18 \mathrm{E}+03$ & $1.85 E+01$ & $-2.99 \mathrm{E}-01$ & $7.02 E-02$ \\
\hline $4.15 E+00$ & $1.05 E+03$ & $1.08 E+03$ & $1.95 E+01$ & $-2.10 \mathrm{E}-01$ & $1.14 E-01$ \\
\hline $4.45 E+00$ & $9.63 \bar{E}+02$ & $9.89 \mathrm{E}+02$ & $2.05 E+01$ & $-2.92 E-01$ & $2.06 \mathrm{E}-01$ \\
\hline $4.75 E+00$ & $8.46 \mathrm{E}+02$ & $8.71 E+02$ & $2.16 E+01$ & $-3.10 \mathrm{E}-01$ & $2.12 \mathrm{E}-01$ \\
\hline $5.04 E+00$ & $7.25 E+02$ & $7.47 \mathrm{E}+02$ & $2.26 \mathrm{E}+01$ & $-1.94 E-01$ & $1.50 \mathrm{E}-01$ \\
\hline $5.34 E+00$ & $6.28 E+02$ & $6.49 E+02$ & $2.35 E+01$ & $-1.52 \mathrm{E}-01$ & $1.50 \mathrm{E}-01$ \\
\hline $5.64 E+00$ & $5.43 E+02$ & $5.65 E+02$ & & & \\
\hline $\begin{array}{c}\text { E1 } \\
(\mathrm{MeV})\end{array}$ & $\begin{array}{c}\mathrm{E2} \\
(\mathrm{MeV})\end{array}$ & $\begin{array}{r}\text { In } \\
\text { neutrons }\end{array}$ & $\begin{array}{l}\text { al } \\
{ }^{k} W^{-1} s^{-1}\end{array}$ & $\begin{array}{r}\text { Error } \\
\text { neutrons } \mathrm{cm}^{-2}\end{array}$ & \\
\hline 0.811 & 1.000 & 1.70 & +03 & $1.30 \mathrm{E}+$ & \\
\hline 1.000 & 1.200 & 1.68 & +03 & $1.04 E+$ & \\
\hline 1.200 & 1.600 & 2.86 & +03 & $1.81 E+$ & \\
\hline 1.600 & 2.000 & 2.26 & +03 & $1.50 \mathrm{E}+$ & \\
\hline 2.000 & 3.000 & 3.52 & +03 & $2.89 E+$ & \\
\hline 3.000 & 4.000 & 1.52 & +03 & $2.18 E+$ & \\
\hline 4.000 & 6.000 & 1.54 & +03 & $2.41 E+$ & \\
\hline 6.000 & 8.000 & 5.50 & +02 & $1.55 \mathrm{E}+$ & \\
\hline 8.000 & 10.000 & 1.59 & +02 & $7.37 E+$ & \\
\hline 10.000 & 12.000 & 4.77 & +01 & $3.27 E+$ & \\
\hline 12.000 & 16.000 & 1.81 & +01 & $2.76 E+$ & \\
\hline 16.000 & 20.000 & 8.5 & -01 & $8.89 E-C$ & \\
\hline 3.000 & 10.000 & 3.78 & +03 & $6.90 E+$ & \\
\hline 1.500 & 15.000 & 1.03 & +04 & $1.23 E+$ & \\
\hline 3.000 & 12.000 & 3.8 & +03 & $7.23 E+$ & \\
\hline
\end{tabular}


Table 29. Neutron spectrum ( $50 \mathrm{keV}$ to $1.4 \mathrm{MeV}$ ) on centerline at $25 \mathrm{~cm}$ behind the lead slabs (Item IIIA) Runs 1606.C, 1606.B, 1606.A

\begin{tabular}{|c|c|c|c|c|}
\hline $\mathrm{N}$ & Energ & ndary & $\begin{array}{c}\text { Flux } \\
\text { (neutrons } \mathrm{cm}^{-2} \mathrm{MeV}^{-1} \mathrm{~kW}^{-1} \mathrm{~s}^{-1} \text { ) }\end{array}$ & $\begin{array}{c}\text { Error } \\
(\%)\end{array}$ \\
\hline \multicolumn{5}{|c|}{ RUN 1606.C } \\
\hline 1 & 0.0394 & 0.0447 & $5.97 \mathrm{E}+04$ & 3.20 \\
\hline 2 & 0.0447 & 0.0534 & $3.41 E+04$ & 3.78 \\
\hline 3 & 0.0534 & 0.0622 & $2.31 E+04$ & 6.43 \\
\hline 4 & 0.0622 & 0.0744 & $2.16 \mathrm{E}+04$ & 5.51 \\
\hline 5 & 0.0744 & 0.0867 & $2.18 E+04$ & 6.37 \\
\hline 6 & 0.0867 & 0.1025 & $1.86 \mathrm{E}+04$ & 6.44 \\
\hline 7 & 0.1025 & 0.1200 & $1.79 \mathrm{E}+04$ & 6.92 \\
\hline 8 & 0.1200 & 0.1410 & $1.82 \mathrm{E}+04$ & 6.32 \\
\hline 9 & 0.1410 & 0.1673 & $1.68 \mathrm{E}+04$ & 6.00 \\
\hline 10 & 0.1673 & 0.1971 & $1.46 \mathrm{E}+04$ & 6.86 \\
\hline \multicolumn{5}{|c|}{ RUN 1606.B } \\
\hline 1 & 0.1436 & 0.1703 & $1.52 \mathrm{E}+04$ & 2.92 \\
\hline 2 & 0.1703 & 0.1971 & $1.42 E+04$ & 3.66 \\
\hline 3 & 0.1971 & 0.2371 & $1.28 \mathrm{E}+04$ & 3.14 \\
\hline 4 & 0.2371 & 0.2772 & $1.27 E+04$ & 3.78 \\
\hline 5 & 0.2772 & 0.3240 & $1.32 \mathrm{E}+04$ & 3.60 \\
\hline 6 & 0.3240 & 0.3841 & $1.31 \mathrm{E}+04$ & 3.17 \\
\hline 7 & 0.3841 & 0.4509 & $1.12 E+04$ & 3.87 \\
\hline 8 & 0.4509 & 0.5310 & $1.28 \mathrm{E}+04$ & 3.10 \\
\hline \multicolumn{5}{|c|}{ RUN 1606.A } \\
\hline 1 & 0.3808 & 0.4452 & $1.13 E+04$ & 2.82 \\
\hline 2 & 0.4452 & 0.5310 & $1.19 \mathrm{E}+04$ & 2.24 \\
\hline 3 & 0.5310 & 0.6169 & $1.09 E+04$ & 2.85 \\
\hline 4 & 0.6169 & 0.7241 & $9.69 E+03$ & 2.85 \\
\hline 5 & 0.7241 & 0.8529 & $9.18 E+03$ & 2.79 \\
\hline 6 & 0.8529 & 1.0031 & $7.74 E+03$ & 3.16 \\
\hline 7 & 1.0031 & 1.1854 & $7.33 E+03$ & 2.99 \\
\hline 8 & 1.1854 & 1.4000 & $7.22 E+03$ & 2.76 \\
\hline
\end{tabular}


Table 30. Spectrum of high-energy neutrons $(>0.8 \mathrm{MeV}$ ) on centerline at $25 \mathrm{~cm}$ behind the lead slabs (Item IIIB): Run 7936

\begin{tabular}{|c|c|c|c|c|c|}
\hline \multirow{2}{*}{$\begin{array}{c}\text { Neutron } \\
\text { Energy } \\
(\mathrm{MeV})\end{array}$} & \multicolumn{2}{|c|}{ Flux (neutrons $\mathrm{cm}^{-2} \mathrm{MeV}^{-1} \mathrm{~kW}^{-1} \mathrm{~s}^{-1}$ ) } & \multirow{2}{*}{$\begin{array}{c}\text { Neutron } \\
\text { Energy } \\
(\mathrm{MeV})\end{array}$} & \multicolumn{2}{|c|}{ Flux (neutrons $\mathrm{cm}^{-2} \mathrm{MeV}^{-1} \mathrm{~kW}^{-1} \mathrm{~s}^{-1}$ ) } \\
\hline & $\begin{array}{l}\text { Lower } \\
\text { Limit }\end{array}$ & $\begin{array}{l}\text { Upper } \\
\text { Limit }\end{array}$ & & $\begin{array}{l}\text { Lower } \\
\text { Limit }\end{array}$ & $\begin{array}{l}\text { Upper } \\
\text { Limit }\end{array}$ \\
\hline 8.11E - 01 & $2.36 E+03$ & $2.43 E+03$ & $5.94 \mathrm{E}+00$ & $2.18 E+02$ & $2.25 E+02$ \\
\hline $9.07 \mathrm{E}-01$ & $2.68 \mathrm{E}+03$ & $2.72 E+03$ & $6.25 E+00$ & $1.89 \mathrm{E}+02$ & $1.96 E+02$ \\
\hline $1.01 E+\infty 0$ & $2.64 E+03$ & $2.67 E+03$ & $6.55 E+00$ & $1.64 E+02$ & $1.70 \mathrm{E}+02$ \\
\hline $1.11 E+\infty 0$ & $2.49 E+03$ & $2.52 \mathrm{E}+03$ & $6.84 E+00$ & $1.40 \mathrm{E}+02$ & $1.44 E+02$ \\
\hline $1.20 E+00$ & $2.37 E+03$ & $2.40 E+03$ & $7.24 \mathrm{E}+00$ & $1.11 E+02$ & $1.15 E+02$ \\
\hline $1.31 E+00$ & $2.26 E+03$ & $2.29 E+03$ & $7.74 \mathrm{E}+00$ & $8.41 E+01$ & $8.88 E+01$ \\
\hline $1.41 E+00$ & $2.17 E+03$ & $2.20 E+03$ & $8.24 E+00$ & $6.09 \mathrm{E}+01$ & $6.59 \mathrm{E}+01$ \\
\hline $1.51 E+00$ & $2.08 E+03$ & $2.10 \mathrm{E}+03$ & $8.76 E+00$ & $4.44 E+01$ & $4.67 E+01$ \\
\hline $1.61 E+00$ & $1.98 E+03$ & $2.00 \mathrm{E}+03$ & $9.26 \mathrm{E}+00$ & $3.17 E+01$ & $3.37 \mathrm{E}+01$ \\
\hline $1.71 E+00$ & $1.87 \mathrm{E}+03$ & $1.89 E+03$ & $9.74 \mathrm{E}+00$ & $2.32 \mathrm{E}+01$ & $2.47 \mathrm{E}+01$ \\
\hline $1.81 E+00$ & $1.76 E+03$ & $1.78 E+03$ & $1.03 E+01$ & $1.76 \mathrm{E}+01$ & $1.91 E+01$ \\
\hline $1.93 E+00$ & $1.67 E+03$ & $1.69 E+03$ & $1.08 E+01$ & $1.35 E+01$ & $1.47 E+01$ \\
\hline $2.10 E+\infty 0$ & $1.52 E+03$ & $1.54 E+03$ & $1.12 E+01$ & $9.85 \mathrm{E}+00$ & $1.08 \mathrm{E}+01$ \\
\hline $2.30 E+00$ & $1.33 E+03$ & $1.35 E+03$ & $1.18 \mathrm{E}+01$ & $6.93 E+\infty 0$ & $7.69 E+00$ \\
\hline $2.50 \mathrm{E}+00$ & $1.16 E+03$ & $1.17 E+03$ & $1.24 E+01$ & $4.74 E+00$ & $5.48 \mathrm{E}+00$ \\
\hline $2.70 E+00$ & $9.77 E+02$ & $9.91 E+02$ & $1.32 \mathrm{E}+01$ & $2.69 \mathrm{E}+00$ & $3.15 E+\infty 0$ \\
\hline $2.90 \mathrm{E}+00$ & $8.30 \mathrm{E}+02$ & $8.45 E+02$ & $1.40 E+01$ & $1.16 \mathrm{E}+00$ & $1.55 E+00$ \\
\hline $3.10 E+00$ & $7.03 E+02$ & $7.19 E+02$ & $1.48 \mathrm{E}+01$ & 5.71E -01 & 8.88E -01 \\
\hline $3.30 E+00$ & $5.99 E+02$ & $6.13 E+02$ & $1.56 \mathrm{E}+01$ & $4.20 E-01$ & $6.96 E-01$ \\
\hline $3.50 \mathrm{E}+00$ & $5.25 E+02$ & $5.40 E+02$ & $1.65 E+01$ & $2.59 \mathrm{E}-01$ & $4.58 \mathrm{E}-01$ \\
\hline $3.71 E+00$ & $4.77 E+02$ & $4.89 E+02$ & $1.75 E+01$ & $-3.53 E-02$ & $1.11 \mathrm{E}-01$ \\
\hline $3.91 E+00$ & $4.46 E+02$ & $4.56 E+02$ & $1.85 E+01$ & $-1.03 E-01$ & $2.72 \mathrm{E}-02$ \\
\hline $4.15 E+00$ & $4.23 E+02$ & $4.33 E+02$ & $1.95 E+01$ & $-5.75 E-02$ & $4.74 E-02$ \\
\hline $4.45 E+00$ & $4.01 E+02$ & $4.09 E+02$ & $2.05 E+01$ & $-1.21 \mathrm{E}-01$ & 4.07E -02 \\
\hline $4.75 E+00$ & $3.70 E+022$ & $3.78 \mathrm{E}+02$ & $2.16 E+01$ & $-1.35 E-01$ & $3.38 E-02$ \\
\hline $5.04 E+00$ & $3.33 E+02$ & $3.41 E+02$ & $2.26 \mathrm{E}+01$ & $-6.42 E-02$ & $4.61 \mathrm{E}-02$ \\
\hline $5.34 \mathrm{E}+00$ & $2.91 E+02$ & $2.98 \mathrm{E}+02$ & $2.35 \mathrm{E}+01$ & $-3.30 E-02$ & $6.42 \mathrm{E}-02$ \\
\hline $5.64 \mathrm{E}+00$ & $2.51 E+02$ & $2.58 \mathrm{E}+02$ & & & \\
\hline
\end{tabular}

\begin{tabular}{cccc}
$\begin{array}{c}\mathrm{E} 1 \\
(\mathrm{MeV})\end{array}$ & $\begin{array}{c}\mathrm{E} 2 \\
(\mathrm{MeV})\end{array}$ & $\begin{array}{c}\text { Integral } \\
\text { neutrons } \mathrm{cm}^{-2} \mathrm{~kW}^{-1} \mathrm{~s}^{-1}\end{array}$ & $\begin{array}{c}\text { Error } \\
\text { neutrons } \mathrm{cm}^{-2} \mathrm{~kW}^{-1} \mathrm{~s}^{-1}\end{array}$ \\
\hline 0.811 & 1.000 & $4.99 \mathrm{E}+02$ & $4.51 \mathrm{E}+00$ \\
1.000 & 1.200 & $5.03 \mathrm{E}+02$ & $2.72 \mathrm{E}+00$ \\
1.200 & 1.600 & $8.77 \mathrm{E}+02$ & $5.33 \mathrm{E}+00$ \\
1.600 & 2.000 & $7.17 \mathrm{E}+02$ & $4.07 \mathrm{E}+00$ \\
2.000 & 3.000 & $1.17 \mathrm{E}+03$ & $8.22 \mathrm{E}+00$ \\
3.000 & 4.000 & $5.57 \mathrm{E}+02$ & $6.68 \mathrm{E}+00$ \\
4.000 & 6.000 & $6.73 \mathrm{E}+02$ & $7.72 \mathrm{E}+00$ \\
6.000 & 8.000 & $2.71 \mathrm{E}+02$ & $5.25 \mathrm{E}+00$ \\
8.000 & 10.000 & $8.31 \mathrm{E}+01$ & $2.62 \mathrm{E}+00$ \\
10.000 & 12.000 & $2.52 \mathrm{E}+01$ & $1.11 \mathrm{E}+00$ \\
12.000 & 16.000 & $8.60 \mathrm{E}+00$ & $8.64 \mathrm{E}-01$ \\
16.000 & 20.000 & $3.55 \mathrm{E}-01$ & $2.96 \mathrm{E}-01$ \\
3.000 & 10.000 & $1.58 \mathrm{E}+03$ & $2.24 \mathrm{E}+01$ \\
1.500 & 15.000 & $3.71 \mathrm{E}+03$ & $3.77 \mathrm{E}+01$ \\
3.000 & 12.000 & $1.61 \mathrm{E}+03$ & $2.35 \mathrm{E}+01$ \\
\hline
\end{tabular}


Table 31. Neutron spectrum ( $50 \mathrm{keV}$ to $1.4 \mathrm{MeV}$ ) on centerline at $25 \mathrm{~cm}$ behind the lead slabs (Item IIB) Runs 1607.C, 1607.B, 1607.A

\begin{tabular}{|c|c|c|c|c|}
\hline $\mathbf{N}$ & \multicolumn{2}{|c|}{$\begin{array}{l}\text { Energy Boundary } \\
(\mathrm{MeV})\end{array}$} & $\begin{array}{c}\text { Flux } \\
\text { (neutrons } \mathrm{cm}^{-2} \mathrm{MeV}^{-1} \mathrm{~kW}^{-1} \mathrm{~s}^{-1} \text { ) }\end{array}$ & $\begin{array}{c}\text { Error } \\
(\%)\end{array}$ \\
\hline \multicolumn{5}{|c|}{ RUN 1607.C } \\
\hline 1 & 0.0452 & 0.0523 & $1.33 E+04$ & 3.48 \\
\hline 2 & 0.0523 & 0.0629 & $7.81 E+03$ & 4.40 \\
\hline 3 & 0.0629 & 0.0736 & $5.90 \mathrm{E}+03$ & 6.82 \\
\hline 4 & 0.0736 & 0.0860 & $5.75 E+03$ & 6.77 \\
\hline 5 & 0.0860 & 0.1019 & $5.81 E+03$ & 5.77 \\
\hline 6 & 0.1019 & 0.1197 & $4.71 E+03$ & 7.34 \\
\hline 7 & 0.1197 & 0.1409 & $4.56 E+03$ & 7.06 \\
\hline 8 & 0.1409 & 0.1658 & $4.56 E+03$ & 6.74 \\
\hline \multicolumn{5}{|c|}{$\underline{\text { RUN 1607.B }}$} \\
\hline 1 & 0.1184 & 0.1387 & $4.54 \mathrm{E}+03$ & 3.27 \\
\hline 2 & 0.1387 & 0.1658 & $4.03 E+03$ & 3.33 \\
\hline 3 & 0.1658 & 0.1996 & $3.76 \mathrm{E}+03$ & 3.43 \\
\hline 4 & 0.1996 & 0.2334 & $3.57 \mathrm{E}+03$ & 4.32 \\
\hline 5 & 0.2334 & 0.2740 & $3.20 \mathrm{E}+03$ & 4.67 \\
\hline 6 & 0.2740 & 0.3214 & $3.62 E+03$ & 4.12 \\
\hline 7 & 0.3214 & 0.3755 & $3.58 \mathrm{E}+03$ & 4.20 \\
\hline 8 & 0.3755 & 0.4431 & $3.01 E+03$ & 4.49 \\
\hline 9 & 0.4431 & 0.5243 & $3.34 \mathrm{E}+03$ & 3.78 \\
\hline \multicolumn{5}{|c|}{ RUN 1607.A } \\
\hline 1 & 0.3838 & 0.4486 & $3.02 E+03$ & 2.81 \\
\hline 2 & 0.4486 & 0.5243 & $3.21 E+03$ & 2.60 \\
\hline 3 & 0.5243 & 0.6216 & $3.02 E+03$ & 2.40 \\
\hline 4 & 0.6216 & 0.7297 & $2.65 E+03$ & 2.86 \\
\hline 5 & 0.7297 & 0.8595 & $2.62 E+03$ & 2.71 \\
\hline 6 & 0.8595 & 1.0108 & $2.28 E+03$ & 2.98 \\
\hline 7 & 1.0108 & 1.1838 & $2.23 E+03$ & 2.96 \\
\hline 8 & 1.1838 & 1.4000 & $2.14 E+03$ & 2.60 \\
\hline
\end{tabular}


Table 32. Spectrum of high-energy neutrons $(>0.8 \mathrm{MeV})$ on centerline at $25 \mathrm{~cm}$ behind the lead slabs (Item IIIC): Run 7938

\begin{tabular}{|c|c|c|c|c|c|}
\hline \multirow[b]{2}{*}{$\begin{array}{c}\text { Neutron } \\
\text { Energy } \\
(\mathrm{MeV})\end{array}$} & \multicolumn{2}{|c|}{ Flux (neutrons $\mathrm{cm}^{-2} \mathrm{MeV}^{-1} \mathrm{~kW}^{-1} \mathrm{~s}^{-1}$ ) } & \multirow[b]{2}{*}{$\begin{array}{c}\text { Neutron } \\
\text { Energy } \\
(\mathrm{MeV}) \\
\end{array}$} & \multicolumn{2}{|c|}{ Flux (neutrons $\mathrm{cm}^{-2} \mathrm{MeV}^{-1} \mathrm{~kW}^{-1} \mathrm{~s}^{-1}$ ) } \\
\hline & $\begin{array}{l}\text { Lower } \\
\text { Limit }\end{array}$ & $\begin{array}{l}\text { Upper } \\
\text { Limit }\end{array}$ & & $\begin{array}{l}\text { Lower } \\
\text { Limit }\end{array}$ & $\begin{array}{l}\text { Upper } \\
\text { Limit }\end{array}$ \\
\hline 8.11E -01 & $8.39 E+02$ & $8.57 \mathrm{E}+02$ & $5.94 \mathrm{E}+00$ & $4.02 \mathrm{E}+01$ & $4.16 \mathrm{E}+01$ \\
\hline $9.07 E-01$ & $9.46 \mathrm{E}+02$ & $9.56 \mathrm{E}+02$ & $6.25 E+00$ & $3.47 E+01$ & $3.64 E+01$ \\
\hline $1.01 E+00$ & $8.63 E+02$ & $8.69 E+02$ & $6.55 \mathrm{E}+00$ & $3.06 \mathrm{E}+01$ & $3.20 \mathrm{E}+01$ \\
\hline $1.11 E+00$ & $7.09 E+02$ & $7.16 \mathrm{E}+02$ & $6.84 E+00$ & $2.68 E+01$ & $2.79 E+01$ \\
\hline $1.20 \mathrm{E}+00$ & $5.74 \bar{E}+02$ & $5.80 \mathrm{E}+02$ & $7.24 E+\infty 0$ & $2.13 E+01$ & $2.21 E+01$ \\
\hline $1.31 E+00$ & $4.85 E+02$ & $4.91 E+02$ & $7.74 \mathrm{E}+00$ & $1.52 \mathrm{E}+01$ & $1.62 E+01$ \\
\hline $1.41 E+00$ & $4.44 \mathrm{E}+02$ & $4.50 \mathrm{E}+02$ & $8.24 \mathrm{E}+00$ & $1.15 E+01$ & $1.25 E+01$ \\
\hline $1.51 E+00$ & $4.24 E+02$ & $4.30 \mathrm{E}+02$ & $8.76 E+00$ & $9.07 \mathrm{E}+00$ & $9.59 E+00$ \\
\hline $1.61 E+00$ & $4.07 E+02$ & $4.12 E+02$ & $9.26 \mathrm{E}+00$ & $7.06 E+00$ & $7.52 \bar{E}+00$ \\
\hline $1.71 E+00$ & $3.89 E+02$ & $3.94 \mathrm{E}+02$ & $9.74 E+00$ & $5.28 \mathrm{E}+00$ & $5.63 E+00$ \\
\hline $1.81 \mathrm{E}+00$ & $3.71 \mathrm{E}+02$ & $3.76 \mathrm{E}+02$ & $1.03 E+01$ & $3.72 E+00$ & $4.05 E+00$ \\
\hline $1.93 E+00$ & $3.51 \mathrm{E}+02$ & $3.55 E+02$ & $1.08 \mathrm{E}+01$ & $2.74 \mathrm{E}+00$ & $3.03 E+00$ \\
\hline $2.10 E+00$ & $3.16 \mathrm{E}+02$ & $3.20 E+02$ & $1.12 E+01$ & $2.05 E+00$ & $2.27 \mathrm{E}+00$ \\
\hline $2.30 E+00$ & $2.64 \mathrm{E}+02$ & $2.68 \mathrm{E}+02$ & $1.18 \mathrm{E}+01$ & $1.36 E+00$ & $1.54 \mathrm{E}+00$ \\
\hline $2.50 \mathrm{E}+00$ & $2.16 E+02$ & $2.19 E+02$ & $1.24 E+01$ & $8.72 E-01$ & $1.04 \mathrm{E}+00$ \\
\hline $2.70 \mathrm{E}+00$ & $1.78 \mathrm{E}+02$ & $1.81 E+02$ & $1.32 E+01$ & $5.89 \mathrm{E}-01$ & $6.98 \mathrm{E}-01$ \\
\hline $2.90 \mathrm{E}+00$ & $1.55 E+02$ & $1.59 E+02$ & $1.40 \mathrm{E}+01$ & $3.18 \mathrm{E}-01$ & $4.09 E-01$ \\
\hline $3.10 \mathrm{E}+00$ & $1.39 E+02$ & $1.43 E+02$ & $1.48 E+01$ & $1.82 \mathrm{E}-01$ & $2.53 \mathrm{E}-01$ \\
\hline $3.30 \mathrm{E}+00$ & $1.23 E+02$ & $1.26 \mathrm{E}+02$ & $1.56 \mathrm{E}+01$ & $7.76 \mathrm{E}-02$ & $1.37 \mathrm{E}-01$ \\
\hline $3.50 \mathrm{E}+00$ & $1.11 E+02$ & $1.14 \mathrm{E}+02$ & $1.65 E+01$ & $1.83 E-02$ & $5.65 \mathrm{E}-02$ \\
\hline $3.71 E+00$ & $1.02 \mathrm{E}+02$ & $1.04 E+02$ & $1.75 E+01$ & $-7.58 \mathrm{E}-03$ & $1.98 \mathrm{E}-02$ \\
\hline $3.91 E+00$ & $9.46 \mathrm{E}+01$ & $9.68 E+01$ & $1.85 E+01$ & $-9.50 E-03$ & $1.58 \mathrm{E}-02$ \\
\hline $4.15 E+00$ & $8.78 \mathrm{E}+01$ & $8.99 E+01$ & $1.95 E+01$ & $-5.83 E-03$ & $1.33 E-02$ \\
\hline $4.45 E+00$ & $8.01 E+01$ & $8.19 E+01$ & $2.05 \mathrm{E}+01$ & $-1.72 \mathrm{E}-02$ & $1.14 \mathrm{E}-02$ \\
\hline $4.75 E+\infty 0$ & $7.01 E+01$ & $7.18 \mathrm{E}+01$ & $2.16 E+01$ & $-1.92 \mathrm{E}-02$ & $1.08 \mathrm{E}-02$ \\
\hline $5.04 \mathrm{E}+00$ & $6.10 E+01$ & $6.26 E+01$ & $2.26 E+01$ & $-9.93 E-03$ & $9.52 E-03$ \\
\hline $5.34 E+\infty 0$ & $5.36 \mathrm{E}+01$ & $5.50 E+01$ & $2.35 E+01$ & $-6.79 E-03$ & $1.04 E-02$ \\
\hline $5.64 \mathrm{E}+00$ & $4.65 E+01$ & $4.81 E+01$ & & & \\
\hline
\end{tabular}

\begin{tabular}{cccc}
$\begin{array}{c}\mathrm{E} 1 \\
(\mathrm{MeV})\end{array}$ & $\begin{array}{c}\mathrm{E} 2 \\
(\mathrm{MeV})\end{array}$ & $\begin{array}{c}\text { Integral } \\
\text { neutrons } \mathrm{cm}^{-2} \mathrm{~kW}^{-1} \mathrm{~s}^{-1}\end{array}$ & $\begin{array}{c}\text { Error } \\
\text { neutrons } \mathrm{cm}^{-2} \mathrm{~kW}^{-1} \mathrm{~s}^{-1}\end{array}$ \\
\hline 0.811 & 1.000 & $1.74 \mathrm{E}+02$ & $9.93 \mathrm{E}-01$ \\
1.000 & 1.200 & $1.45 \mathrm{E}+02$ & $6.69 \mathrm{E}-01$ \\
1.200 & 1.600 & $1.86 \mathrm{E}+02$ & $1.16 \mathrm{E}+00$ \\
1.600 & 2.000 & $1.50 \mathrm{E}+02$ & $9.25 \mathrm{E}-01$ \\
2.000 & 3.000 & $2.27 \mathrm{E}+02$ & $1.82 \mathrm{E}+00$ \\
3.000 & 4.000 & $1.16 \mathrm{E}+02$ & $1.47 \mathrm{E}+00$ \\
4.000 & 6.000 & $1.30 \mathrm{E}+02$ & $1.68 \mathrm{E}+00$ \\
6.000 & 8.000 & $5.08 \mathrm{E}+01$ & $1.16 \mathrm{E}+00$ \\
8.000 & 10.000 & $1.71 \mathrm{E}+01$ & $5.92 \mathrm{E}-01$ \\
10.000 & 12.000 & $5.24 \mathrm{E}+00$ & $2.54 \mathrm{E}-01$ \\
12.000 & 16.000 & $1.86 \mathrm{E}+00$ & $1.98 \mathrm{E}-01$ \\
16.000 & 20.000 & $5.58 \mathrm{E}-02$ & $5.65 \mathrm{E}-02$ \\
3.000 & 10.000 & $3.13 \mathrm{E}+02$ & $4.92 \mathrm{E}+00$ \\
1.500 & 15.000 & $7.40 \mathrm{E}+02$ & $8.35 \mathrm{E}+00$ \\
3.000 & 12.000 & $3.18 \mathrm{E}+02$ & $5.17 \mathrm{E}+00$ \\
\hline
\end{tabular}


Table 33. Neutron spectrum ( $50 \mathrm{keV}$ to $1.4 \mathrm{MeV}$ ) on centerline at $25 \mathrm{~cm}$ behind the lead slabs (Item IIIC) Runs 1608.B, 1608.C, 1608.A

\begin{tabular}{|c|c|c|c|c|}
\hline $\mathrm{N}$ & \multicolumn{2}{|c|}{$\begin{array}{l}\text { Energy Boundary } \\
(\mathrm{MeV})\end{array}$} & $\begin{array}{c}\text { Flux } \\
\text { (neutrons } \mathrm{cm}^{-2} \mathrm{MeV}^{-1} \mathrm{~kW}^{-1} \mathrm{~s}^{-1} \text { ) }\end{array}$ & \multirow[t]{2}{*}{$\begin{array}{l}\text { Error } \\
(\%)\end{array}$} \\
\hline \multicolumn{4}{|c|}{ RUN 1608.B } & \\
\hline 1 & 0.0393 & 0.0463 & $5.93 E+03$ & 1.79 \\
\hline 2 & 0.0463 & 0.0550 & $2.70 \mathrm{E}+03$ & 3.50 \\
\hline 3 & 0.0550 & 0.0655 & $1.86 \mathrm{E}+03$ & 4.84 \\
\hline 4 & 0.0655 & 0.0759 & $1.77 \mathrm{E}+03$ & 5.94 \\
\hline 5 & 0.0759 & 0.0899 & $1.71 E+03$ & 5.09 \\
\hline 6 & 0.0899 & 0.1056 & $1.61 E+03$ & 5.48 \\
\hline 7 & 0.1056 & 0.1248 & $1.50 \mathrm{E}+03$ & 5.33 \\
\hline \multicolumn{5}{|c|}{$\underline{\text { RUN } 1608 . C}$} \\
\hline 1 & 0.0911 & 0.1046 & $1.59 E+03$ & 2.18 \\
\hline 2 & 0.1046 & 0.1248 & $1.28 \mathrm{E}+03$ & 2.25 \\
\hline 3 & 0.1248 & 0.1450 & $1.30 E+03$ & 2.61 \\
\hline 4 & 0.1450 & 0.1720 & $1.22 \mathrm{E}+03$ & 2.48 \\
\hline 5 & 0.1720 & 0.1990 & $1.16 \mathrm{E}+03$ & 3.08 \\
\hline 6 & 0.1990 & 0.2328 & $1.08 E+03$ & 3.06 \\
\hline 7 & 0.2328 & 0.2732 & $1.05 E+03$ & 3.02 \\
\hline 8 & 0.2732 & 0.3272 & $1.05 E+03$ & 2.58 \\
\hline \multicolumn{5}{|c|}{$\underline{\text { RUN 1608.A }}$} \\
\hline 1 & 0.2307 & 0.2736 & $1.10 E+03$ & 1.88 \\
\hline 2 & 0.2736 & 0.3272 & $1.01 E+03$ & 1.94 \\
\hline 3 & 0.3272 & 0.3808 & $9.21 E+02$ & 2.52 \\
\hline 4 & 0.3808 & 0.4452 & $8.04 E+02$ & 2.78 \\
\hline 5 & 0.4452 & 0.5310 & $9.42 \mathrm{E}+02$ & 2.01 \\
\hline 6 & 0.5310 & 0.6169 & $1.00 E+03$ & 2.20 \\
\hline 7 & 0.6169 & 0.7241 & $9.27 \mathrm{E}+02$ & 2.08 \\
\hline 8 & 0.7241 & 0.8259 & $9.53 E+02$ & 1.84 \\
\hline 9 & 0.8529 & 1.0031 & $8.38 E+02$ & 1.94 \\
\hline 10 & 1.0031 & 1.1854 & $6.37 \mathrm{E}+02$ & 2.21 \\
\hline 11 & 1.1854 & 1.4000 & $4.48 \mathrm{E}+02$ & 2.82 \\
\hline
\end{tabular}


APPENDIX C

FIGURES 


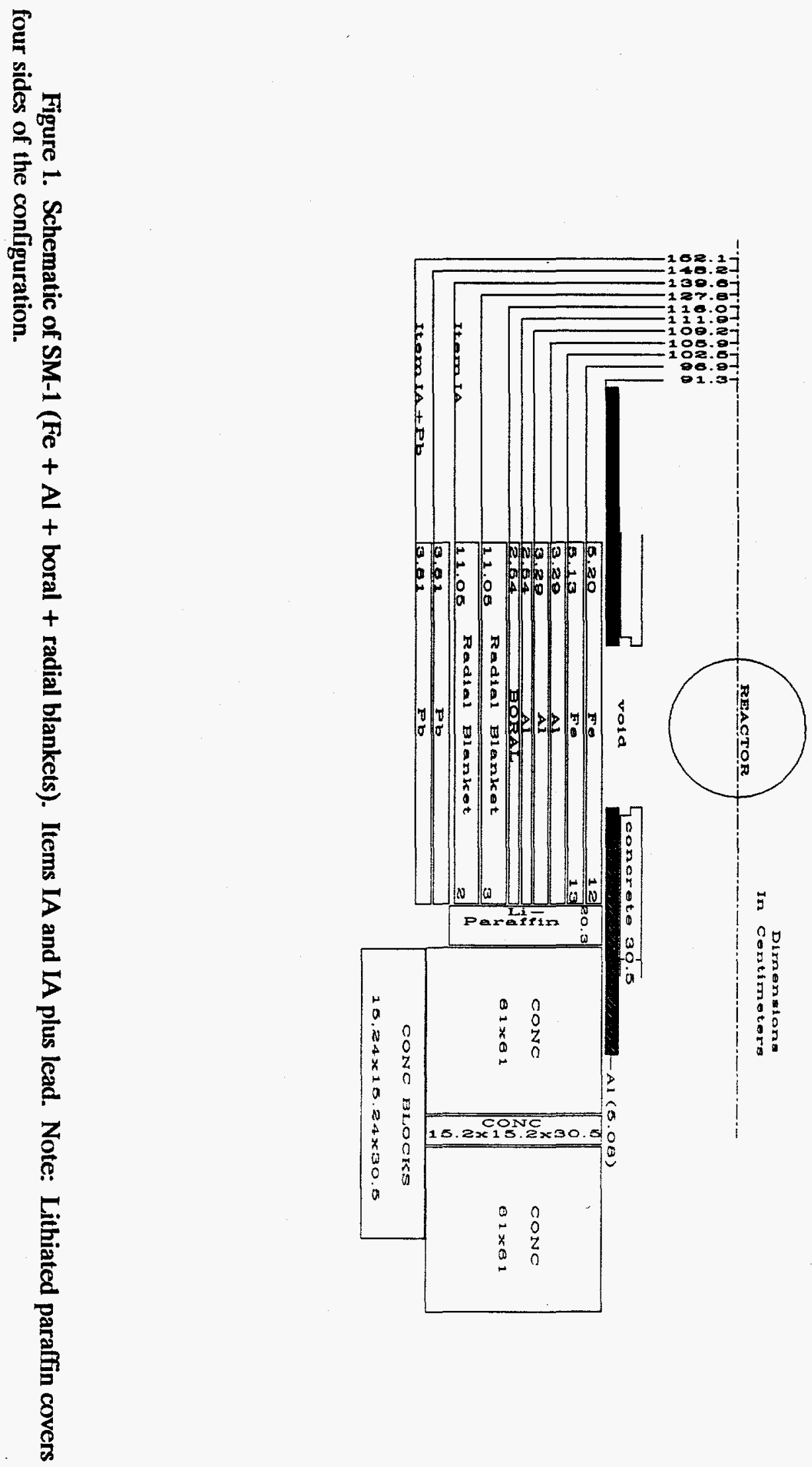
RADIAL BLANKET
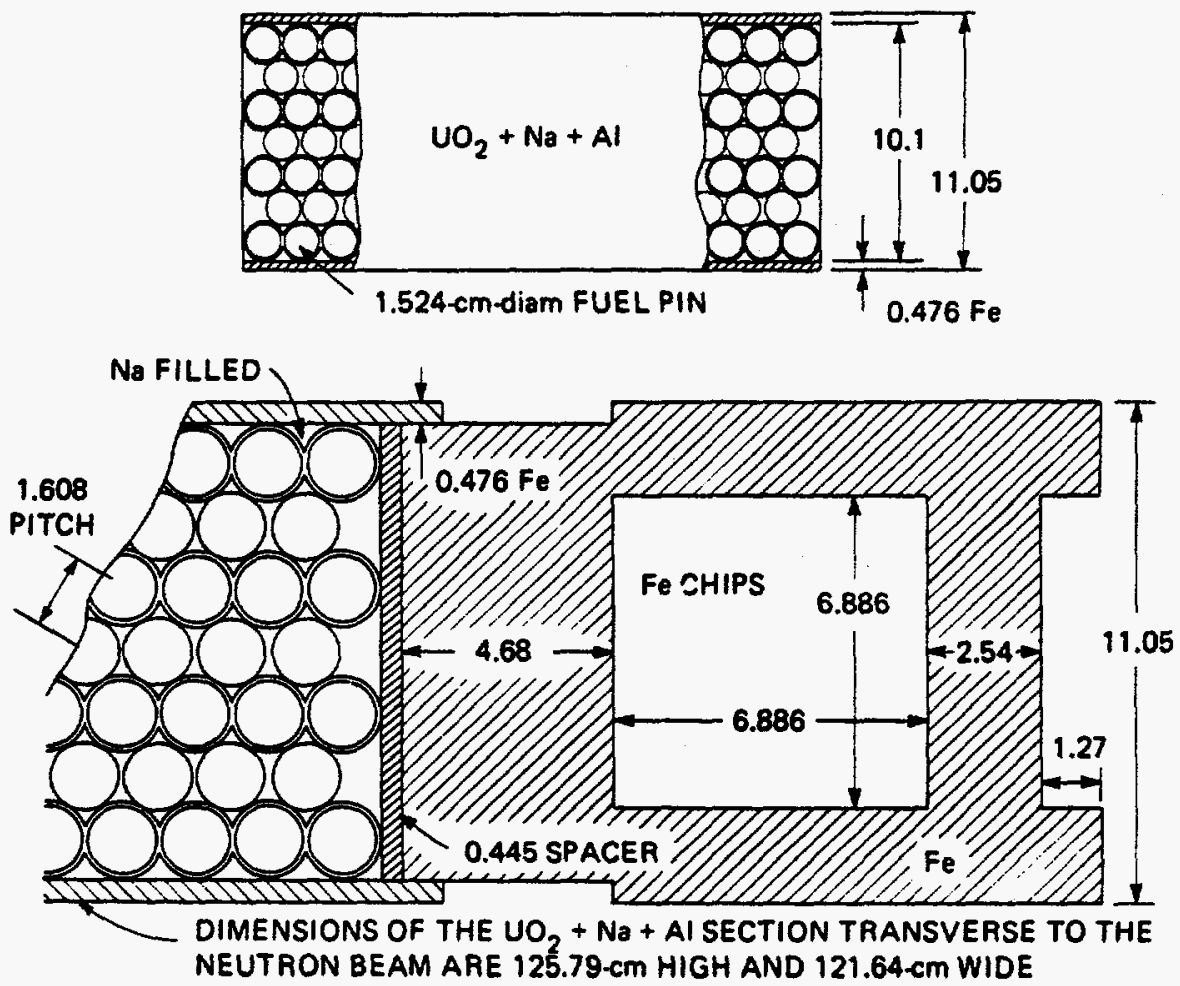

THEORETICAL DENSITY $=10.96 \mathrm{~g} / \mathrm{cC}$ ACTUAL DENSITY $(0.94$ THEO.) $=10.28 \mathrm{~g} / \mathrm{cc}$
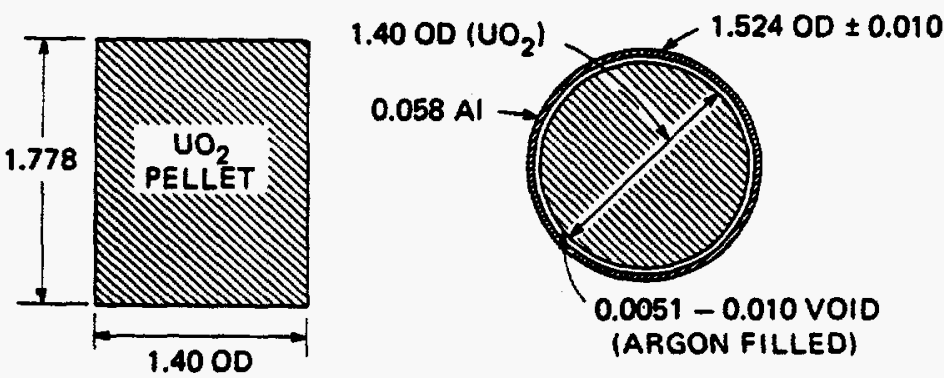

DIMENSIONS IN cm

Figure 2. Schematic of radial blanket slab containing $\mathrm{UO}_{2}$. 
ORNL-DWG 86.12606

\section{$B_{4} C$ CONTAINERS}
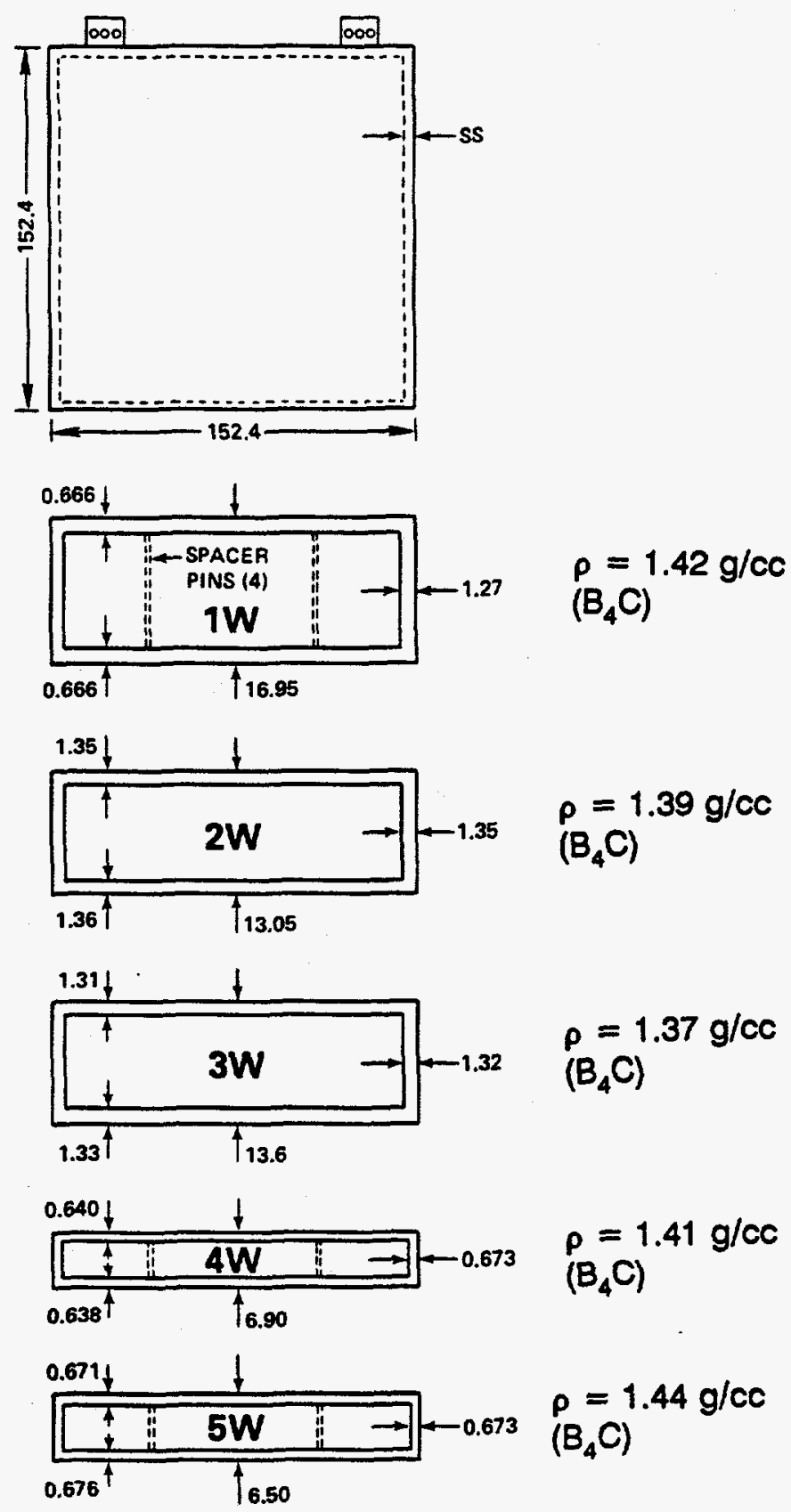

(ALL DIMENSIONS ARE IN CENTIMETERS)

Figure 3. Schematic of stainless steel containers used for boron carbide shield slabs. 


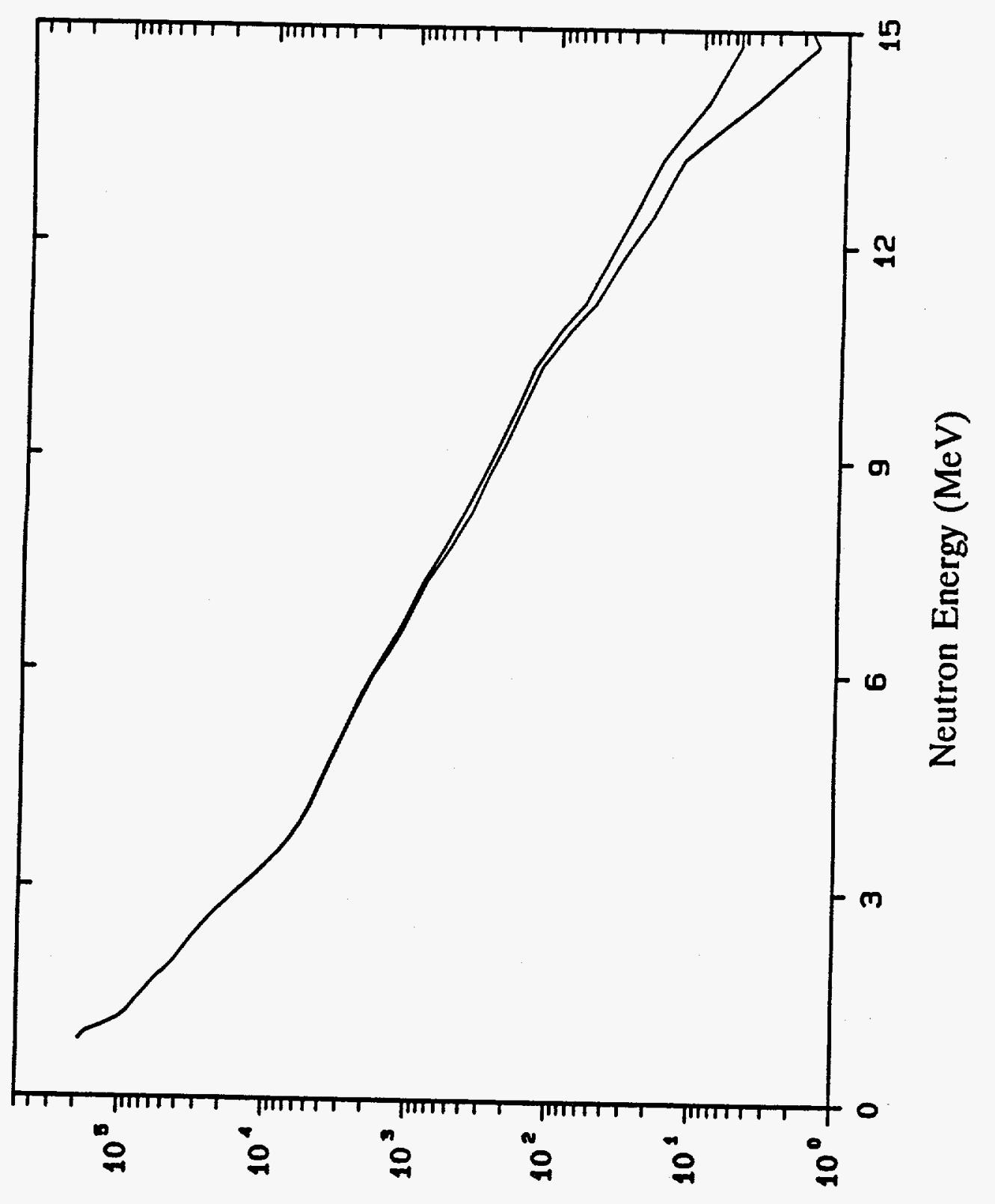

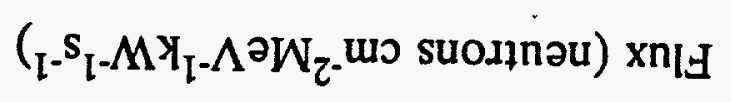




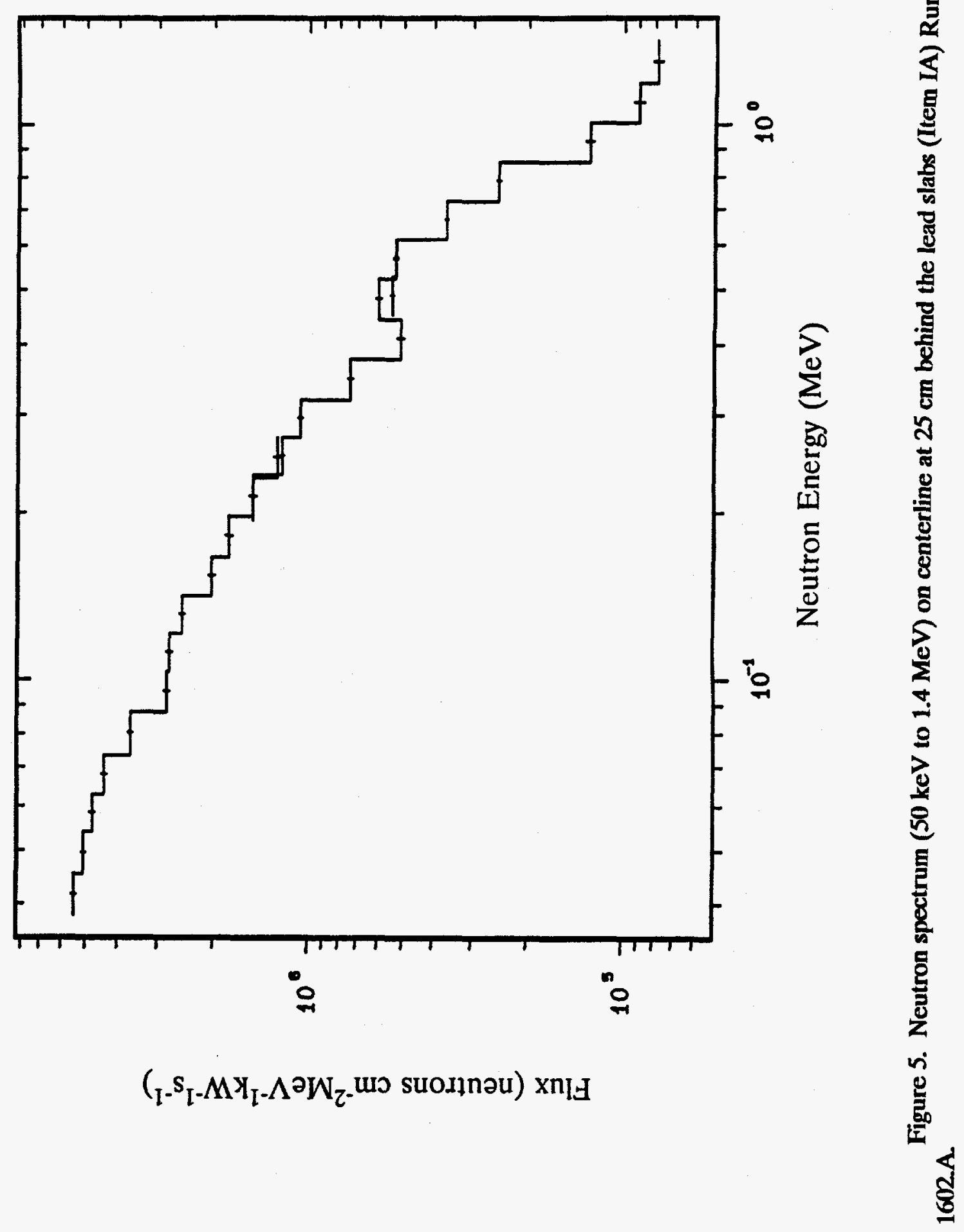




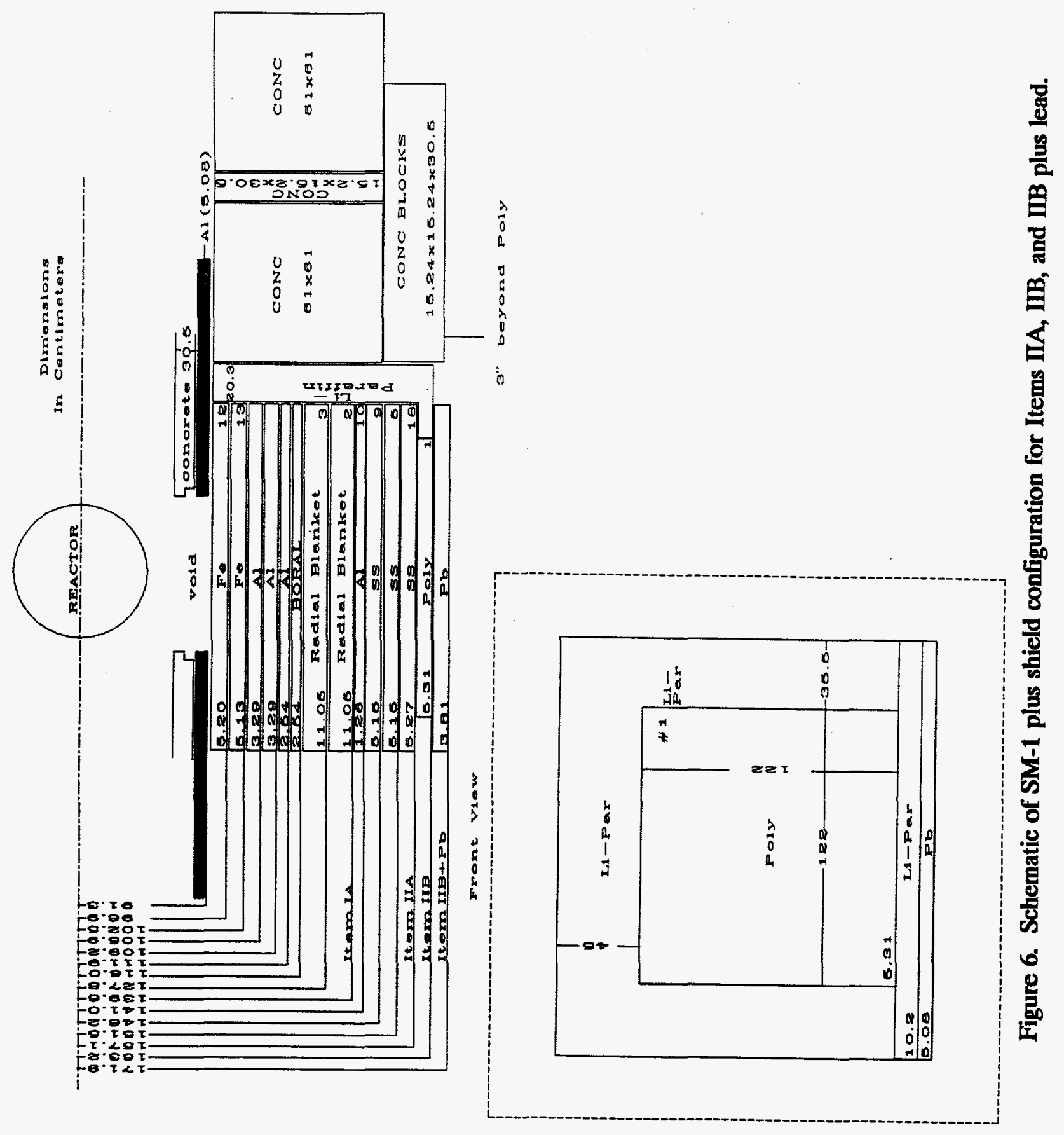




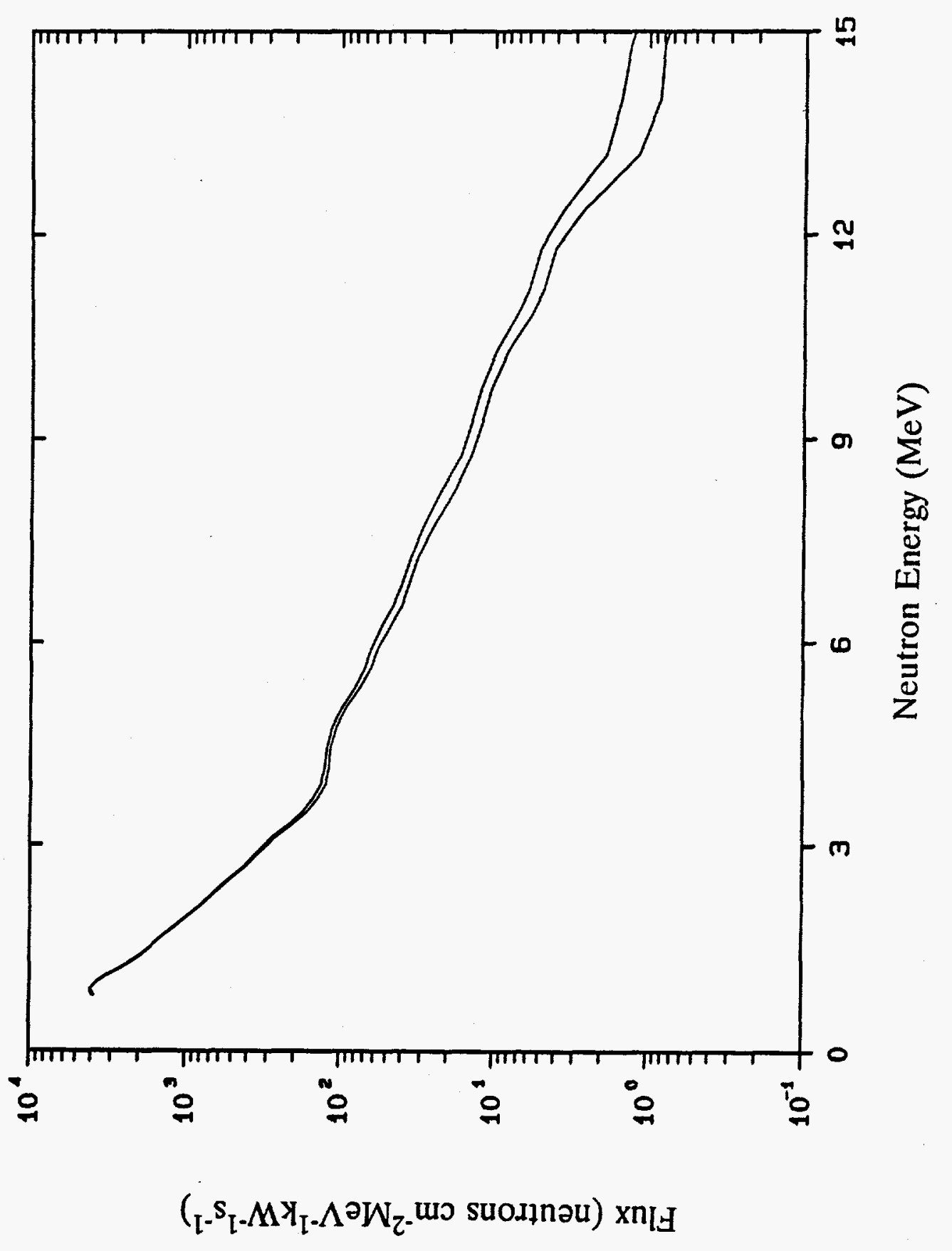

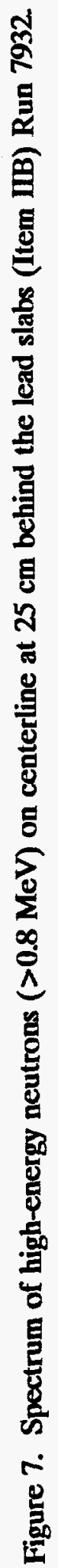




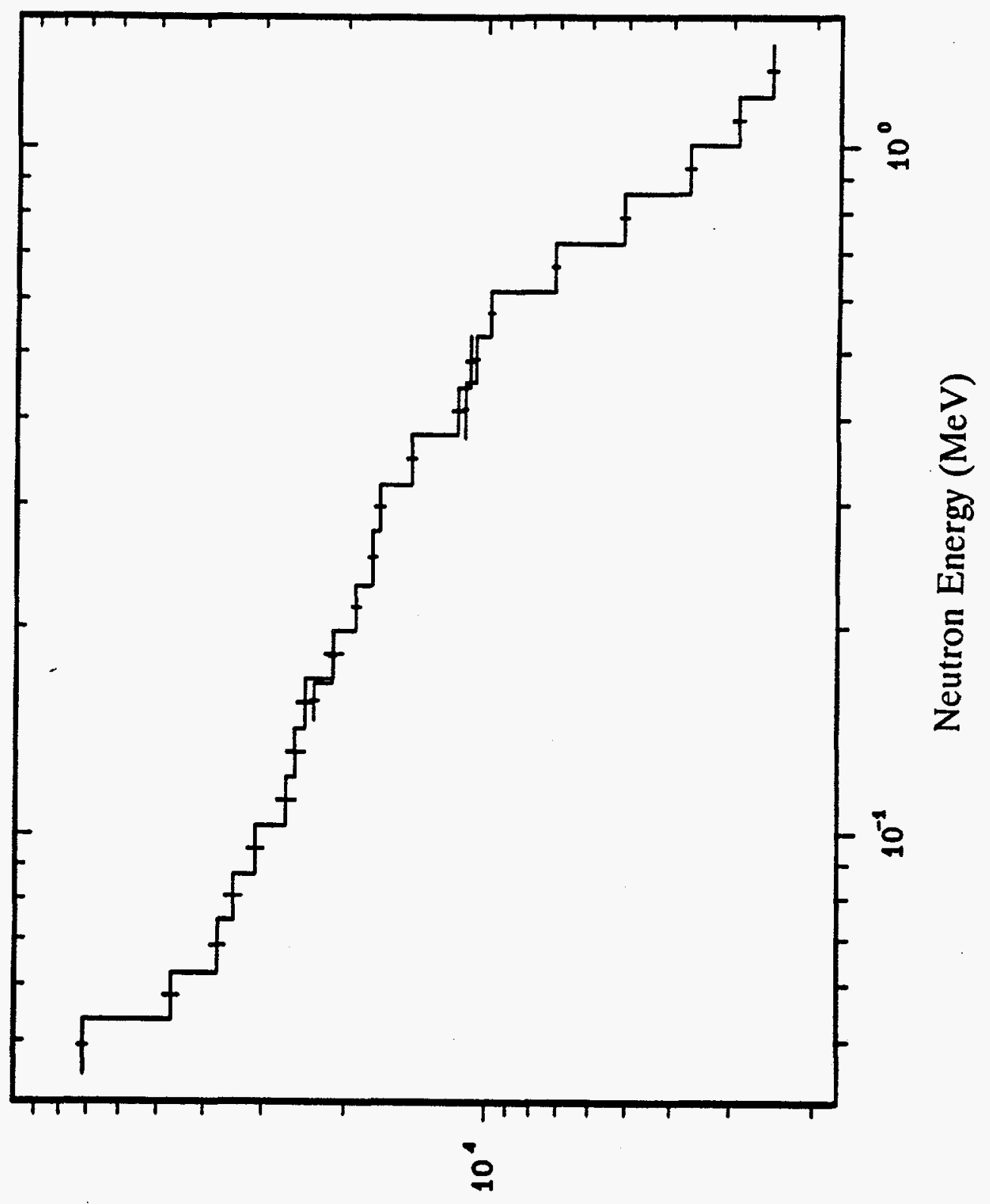

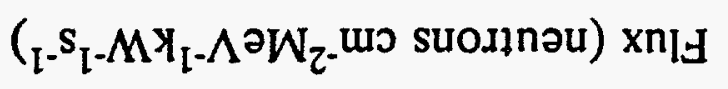

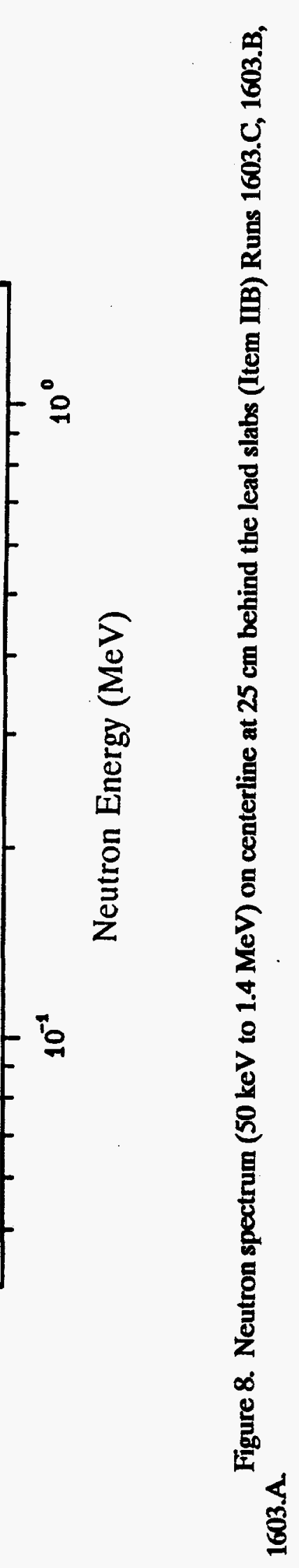




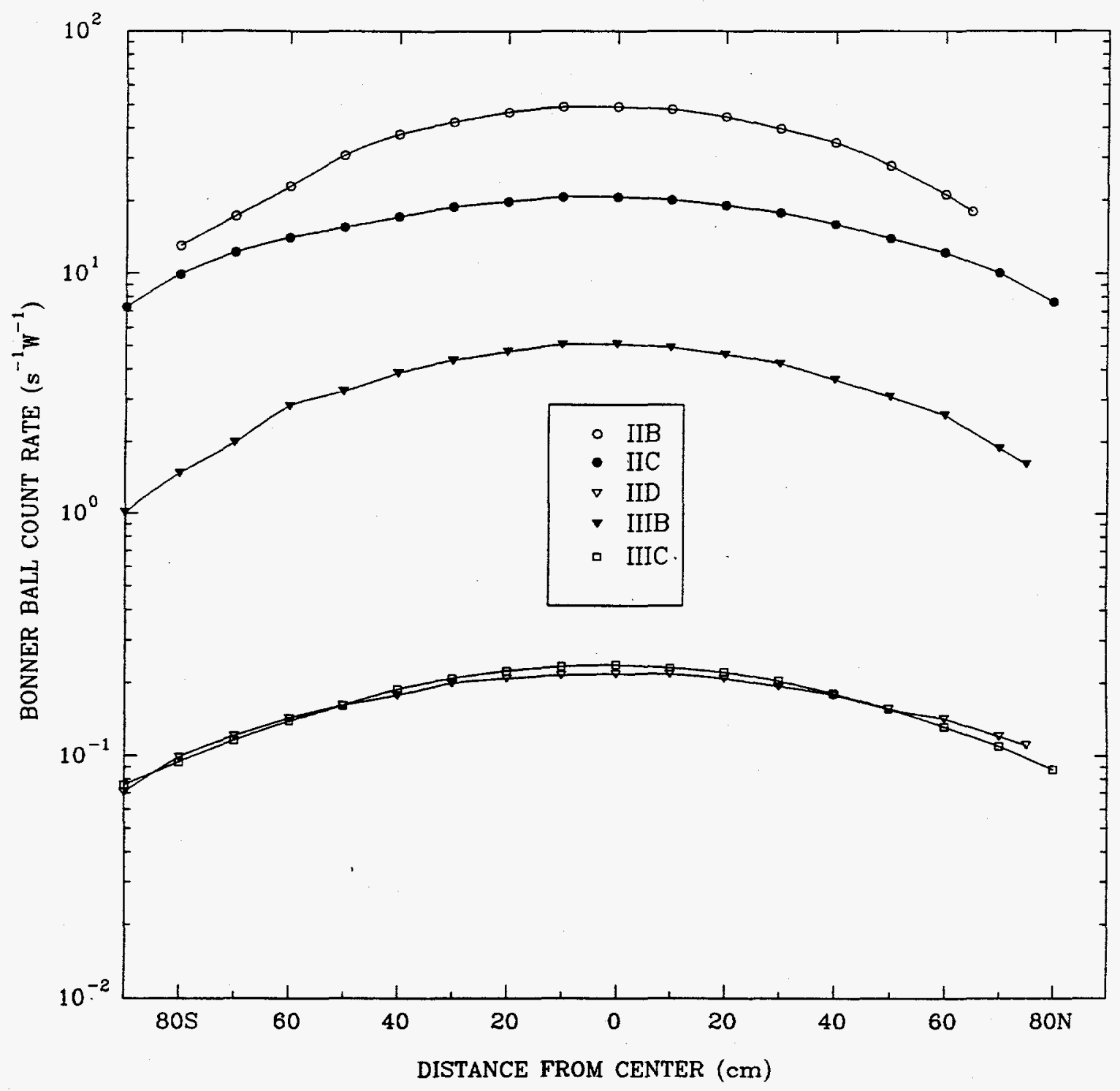

Figure 9. 3-inch Bonner ball traverses through the horizontal midplane at $30 \mathrm{~cm}$ behind a series of configurations (Items IIB-D, IIB, C). 


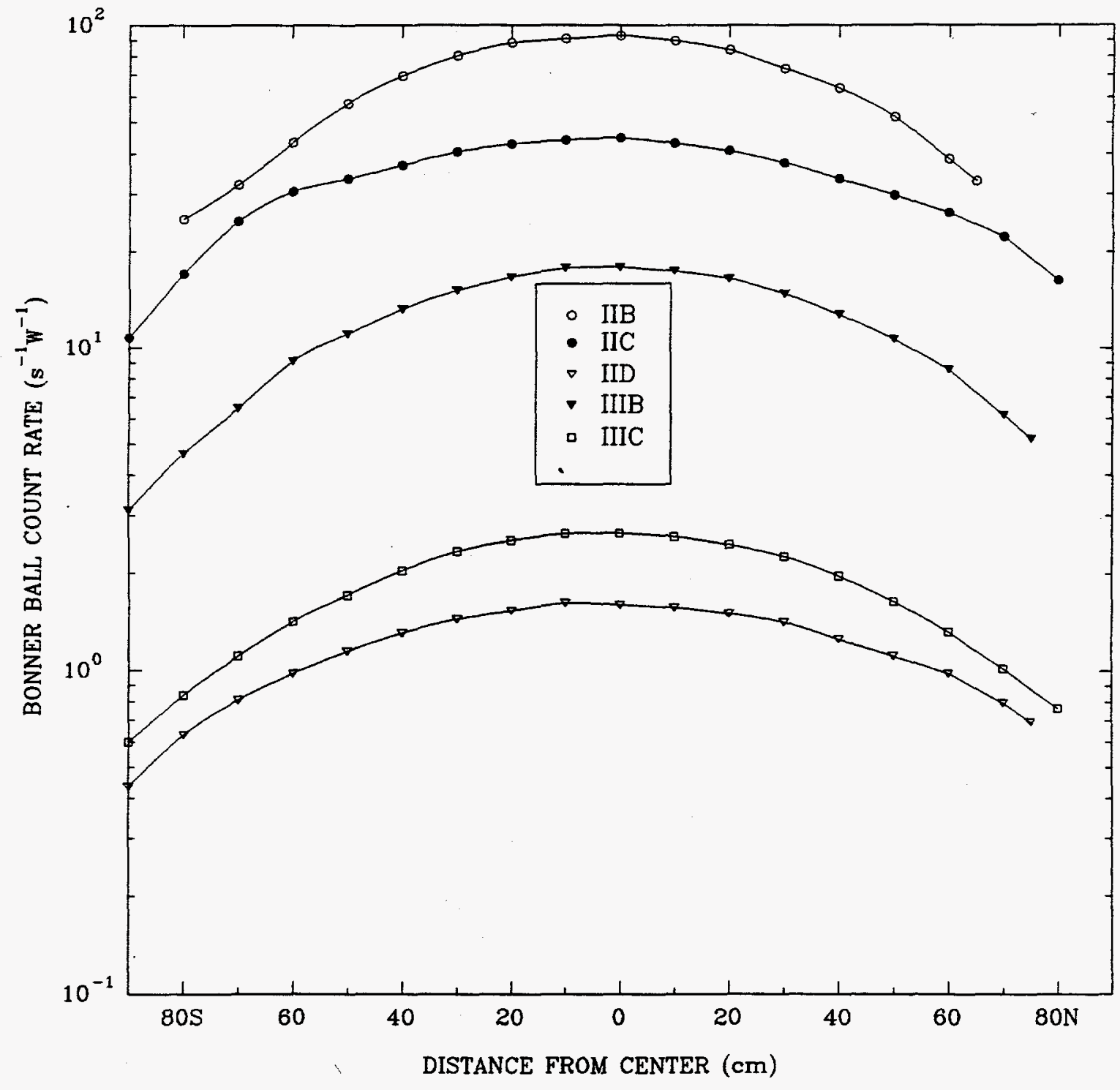

Figure 10. 5-inch Bonner ball traverses through the horizontal midplane at $30 \mathrm{~cm}$ behind a series of configurations (Items IIB-D, IMB, C). 


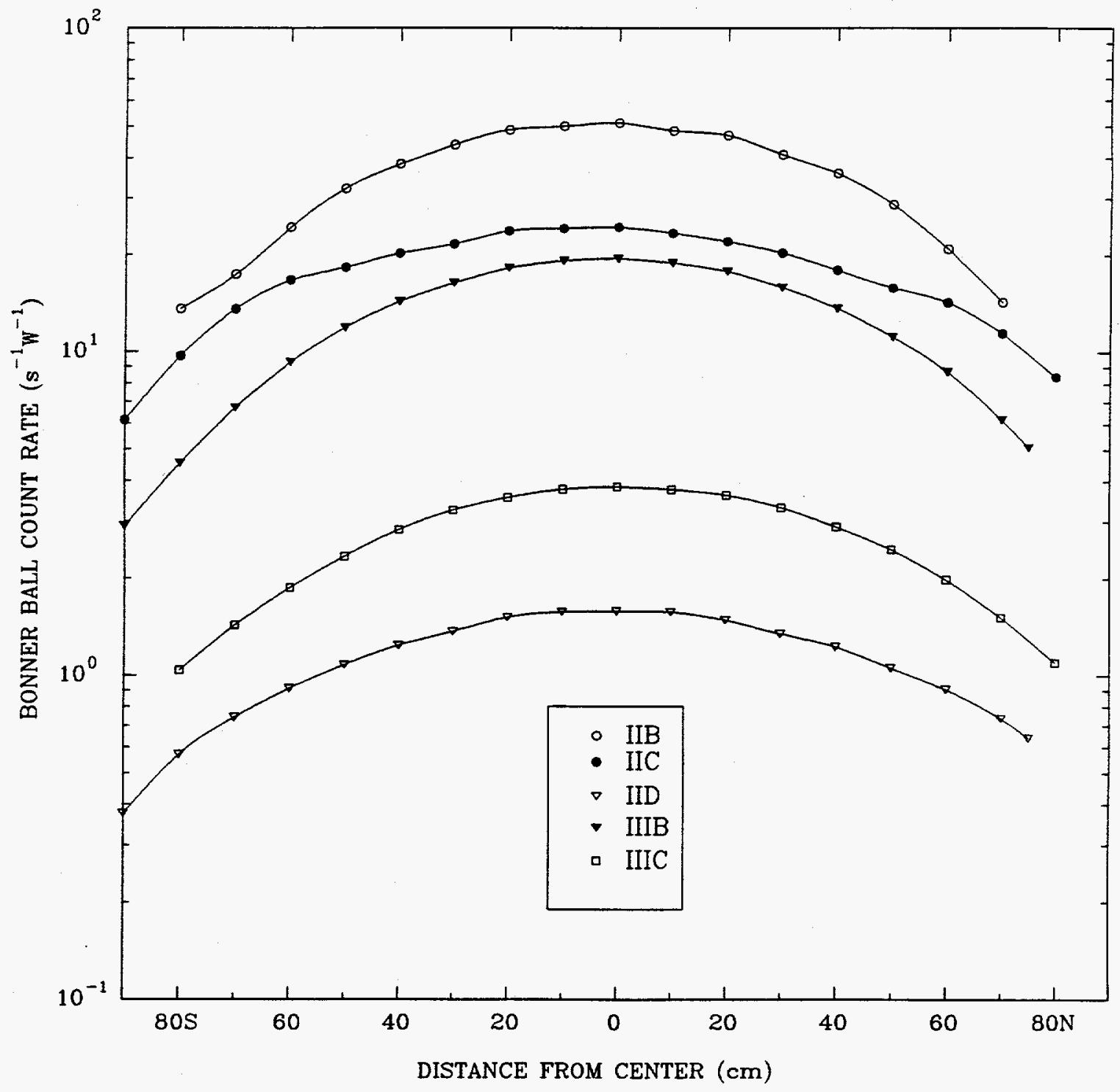

Figure 11. 8-inch Bonner ball traverses through the horizontal midplane at $30 \mathrm{~cm}$ behind a series of configurations (Items IIB-D, IIIB, C). 

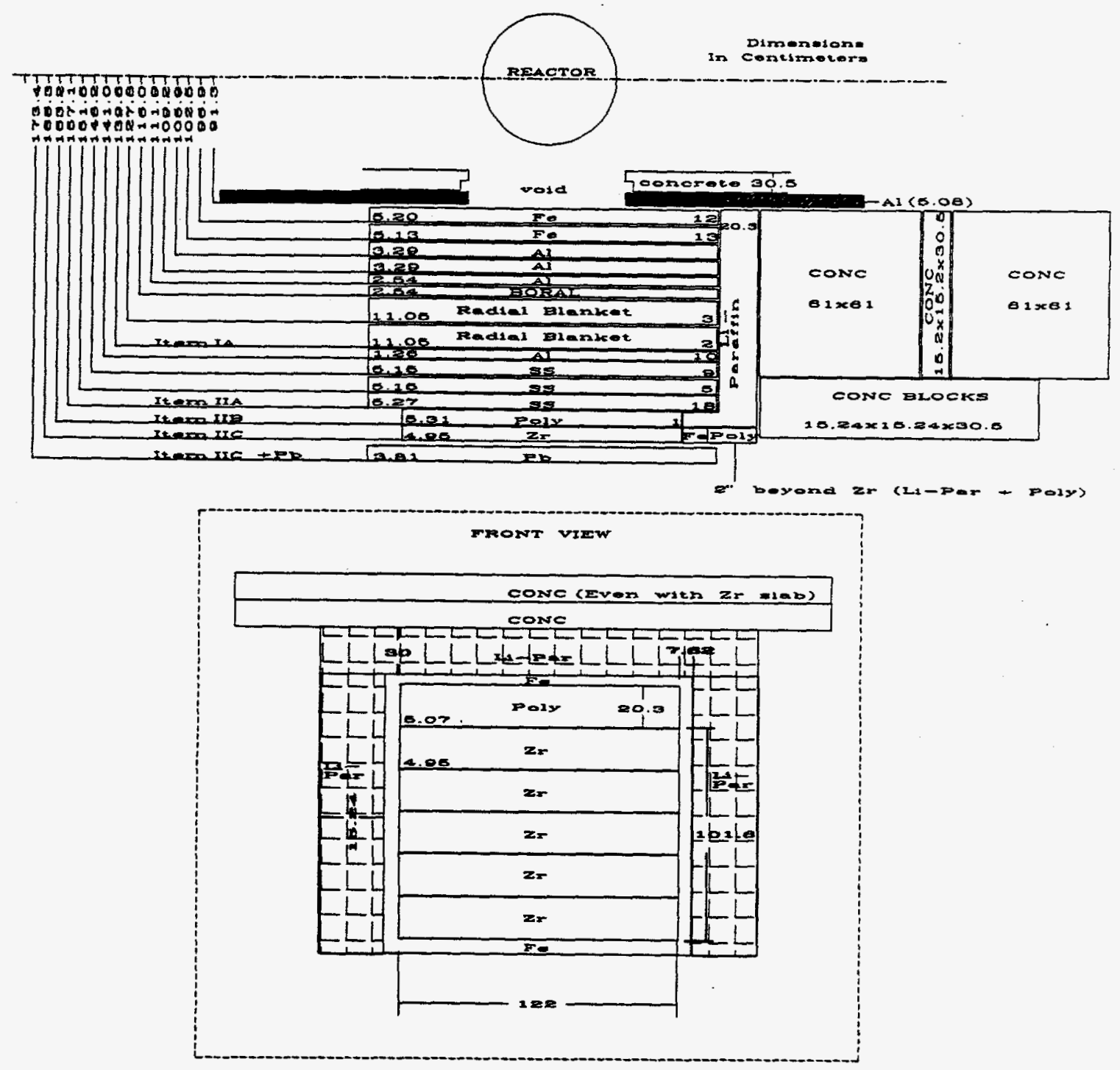

Figure 12. Schematic of SM-1 plus shield configuration for Items IIC and IC plus lead. 


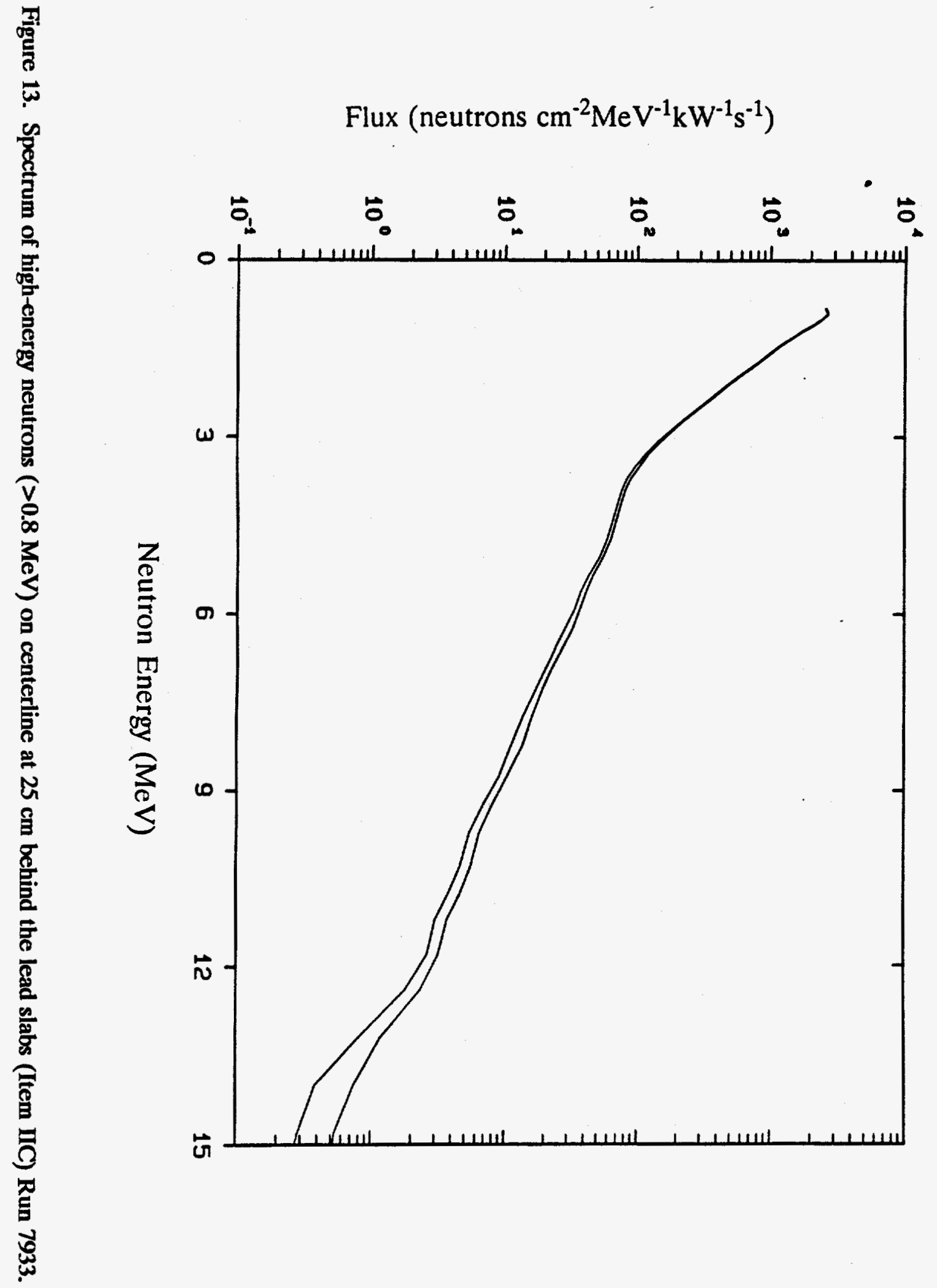




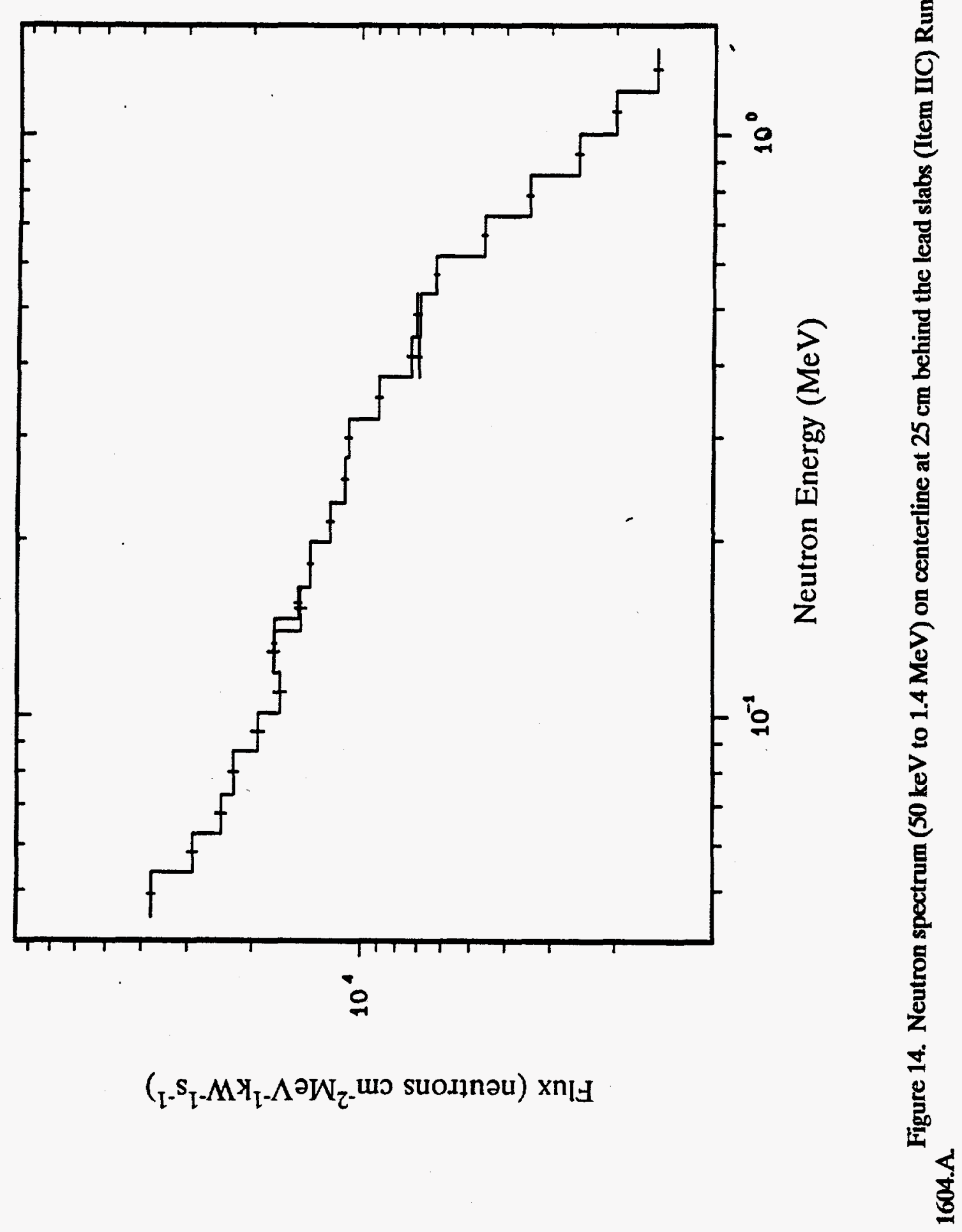




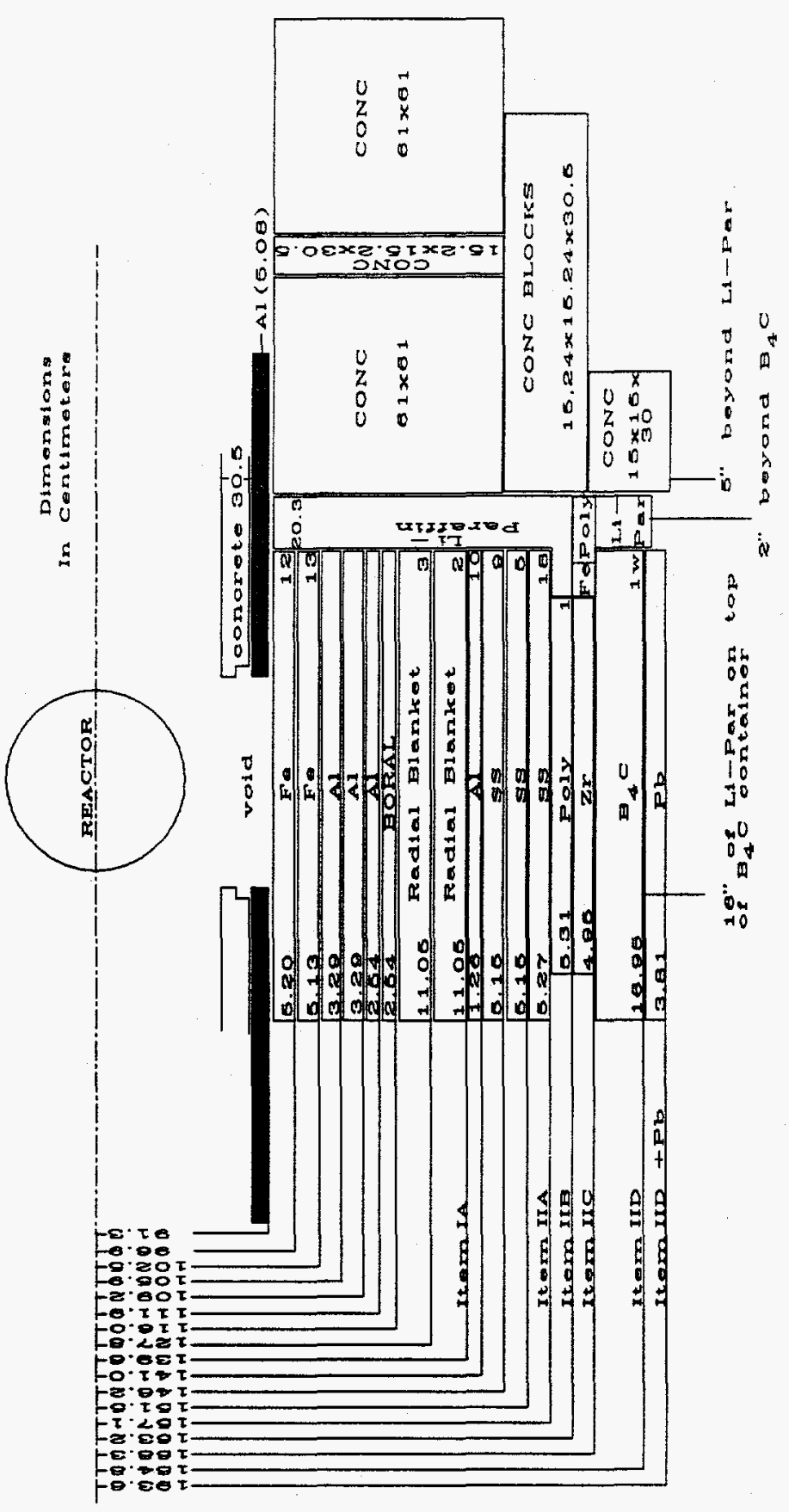

영

응

뭉

豆

旨

5

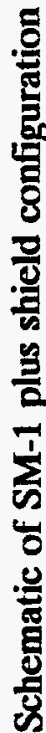

เ

造 


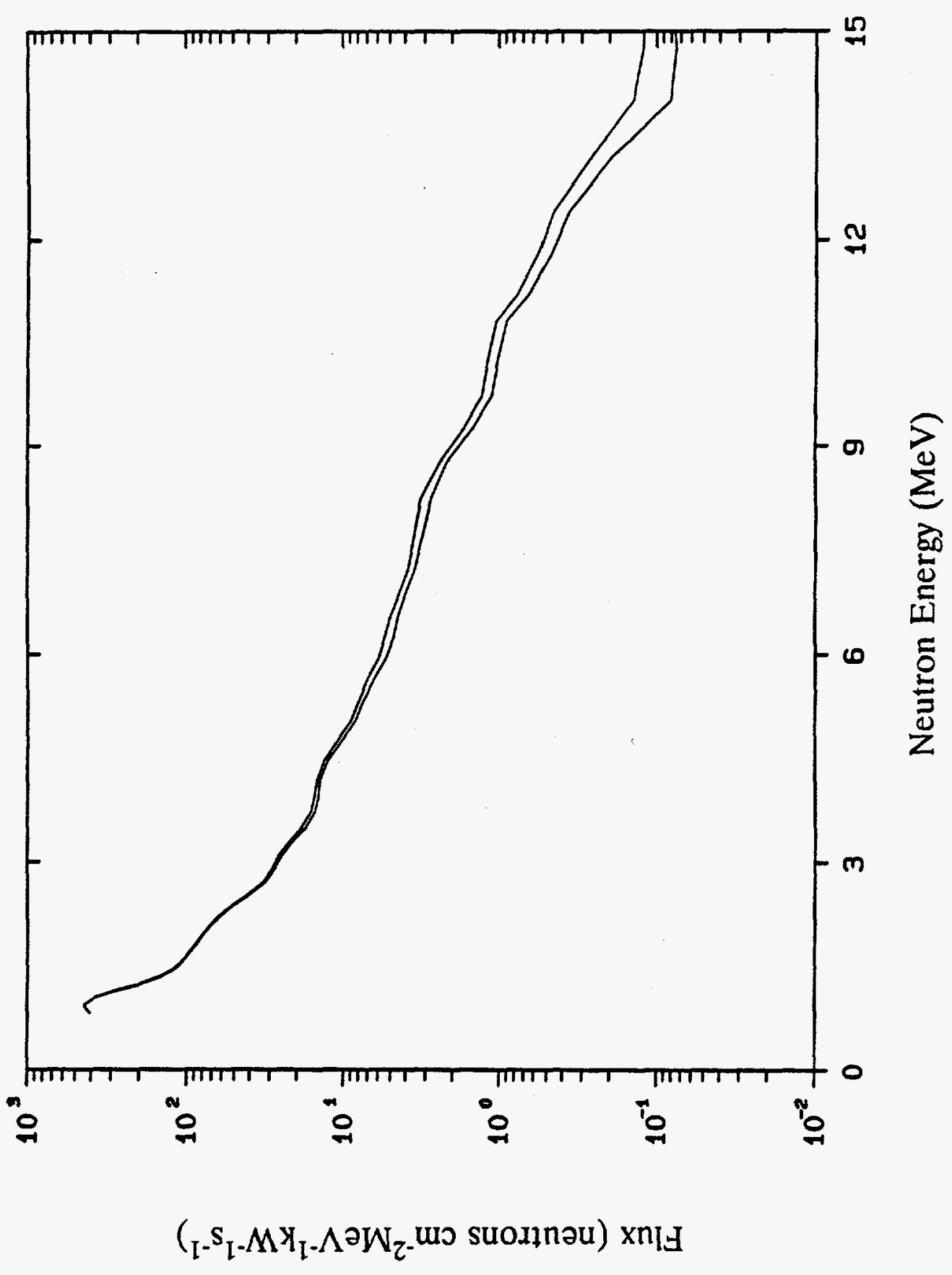




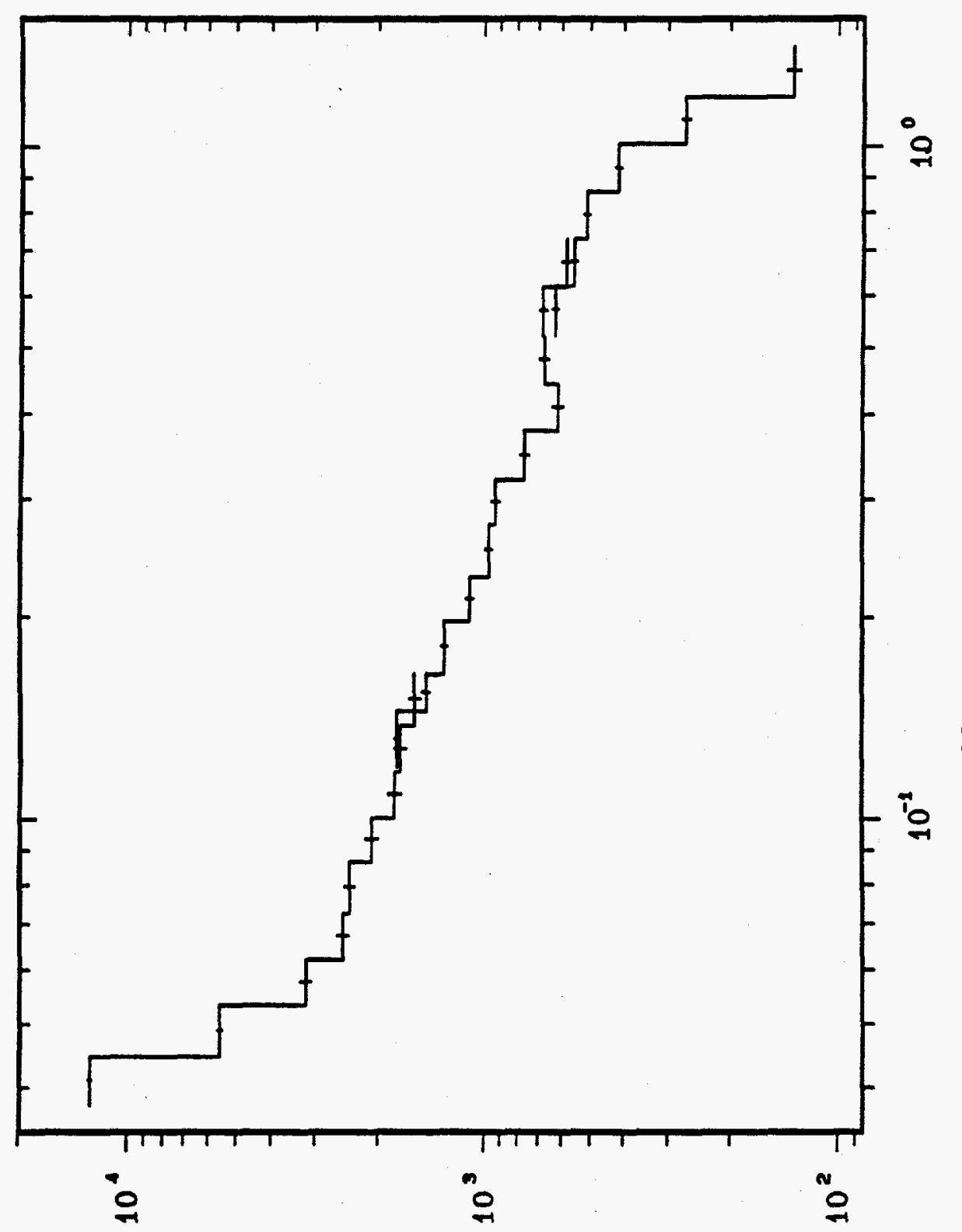

8 

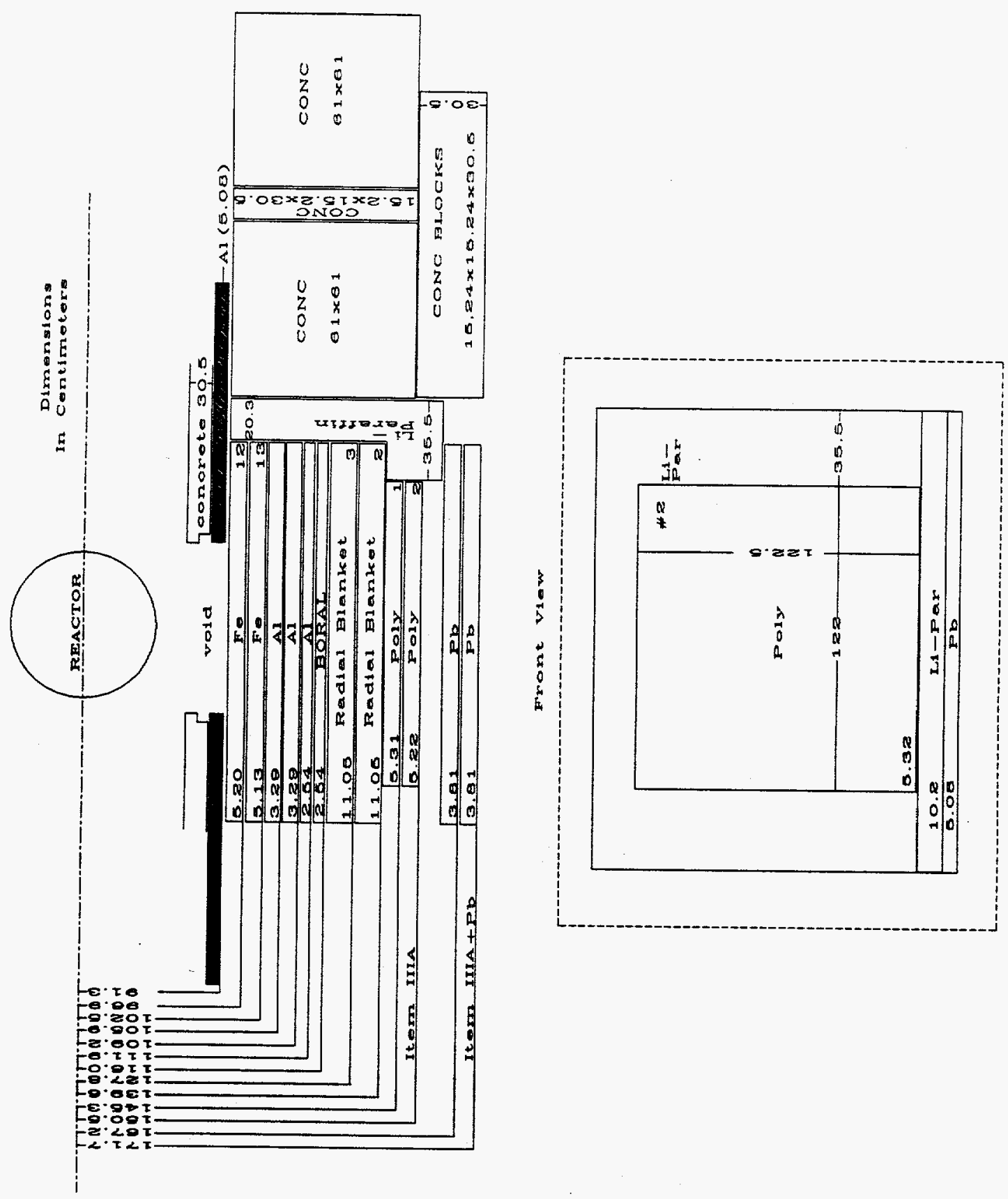

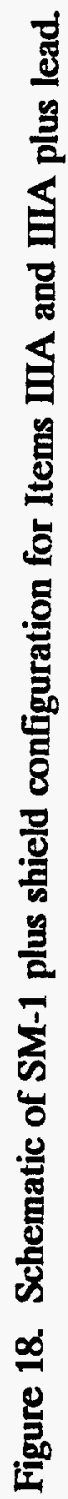




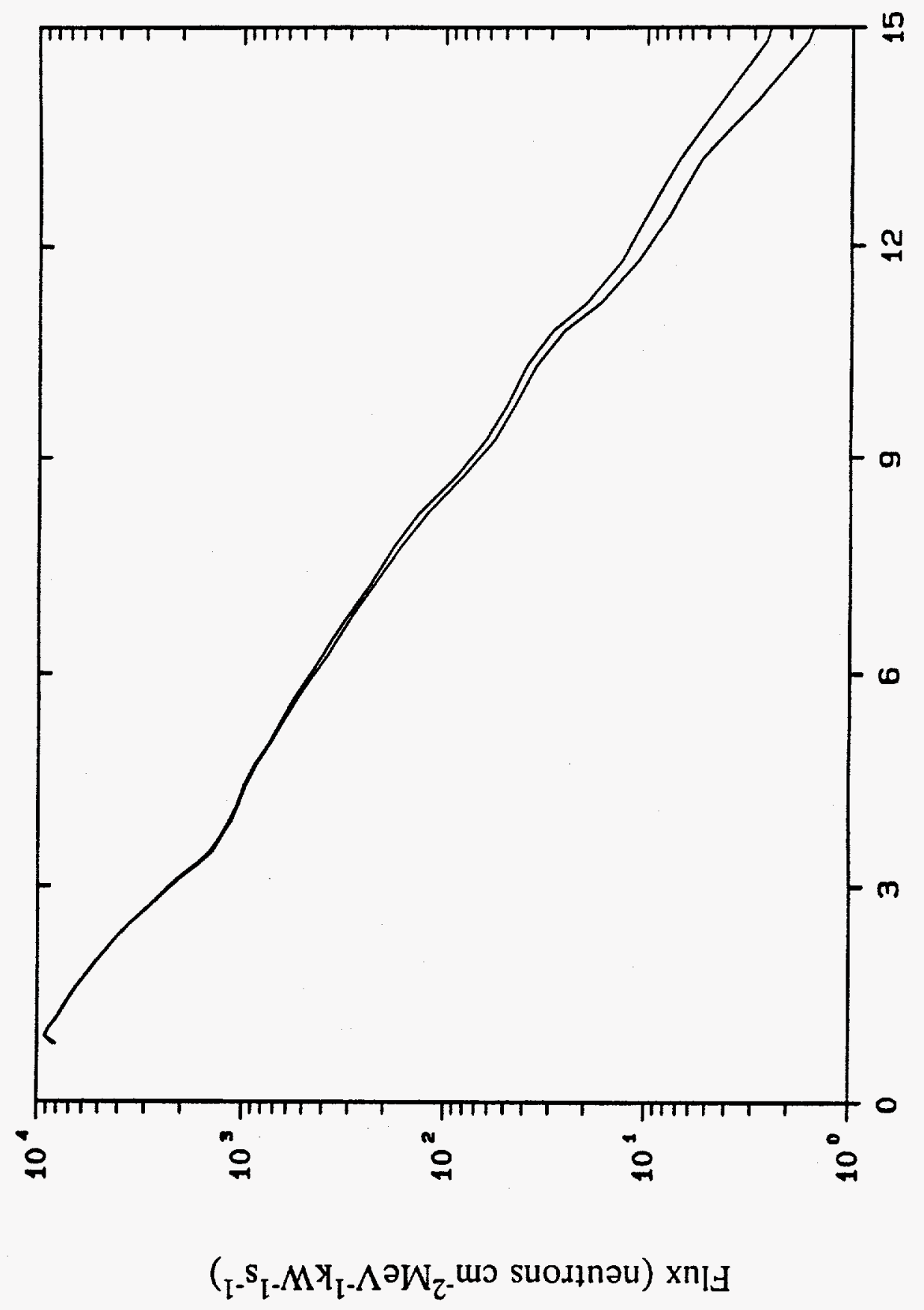

ริ่

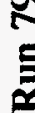

$\$$

$\sum_{0}^{8}$

$\sum$ ฟ

त म

克

.

옹

5

$\underbrace{\infty}_{\substack{0 \\ 0}}$

물

을

a

递 


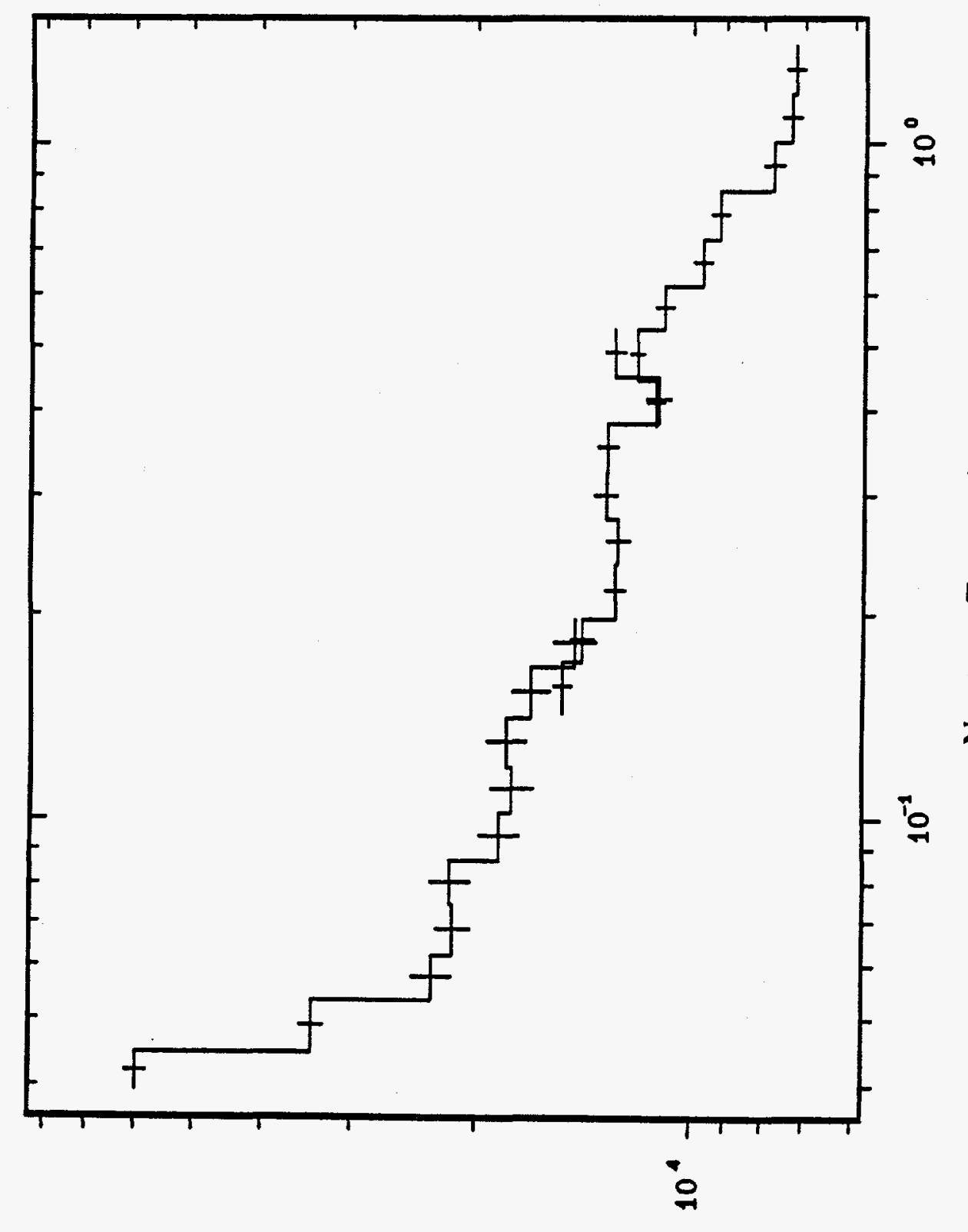

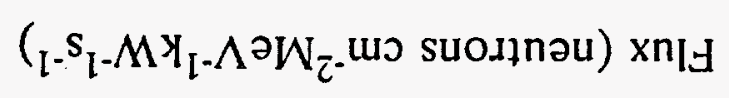




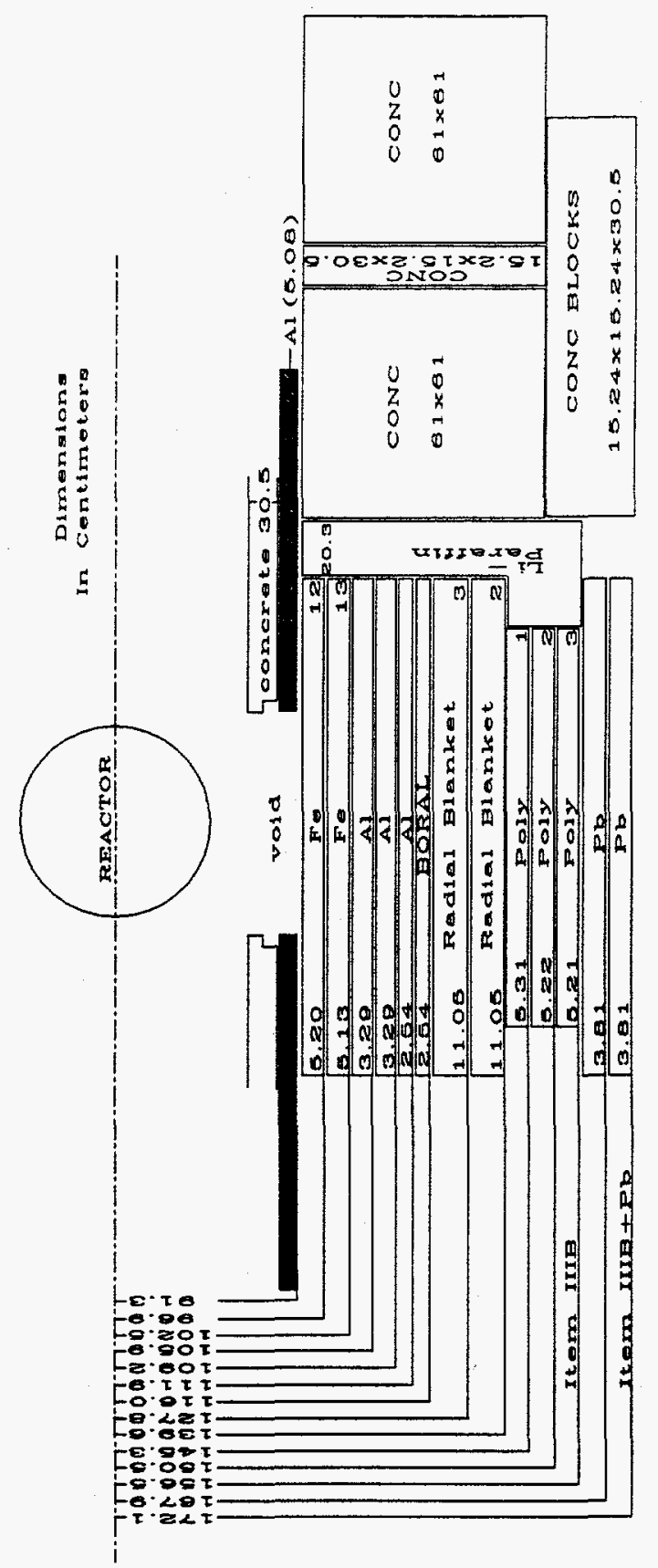

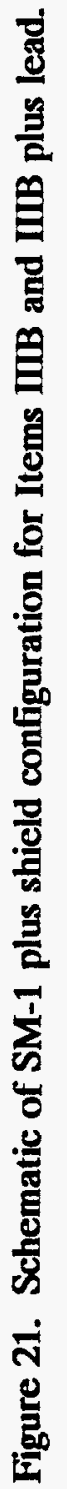




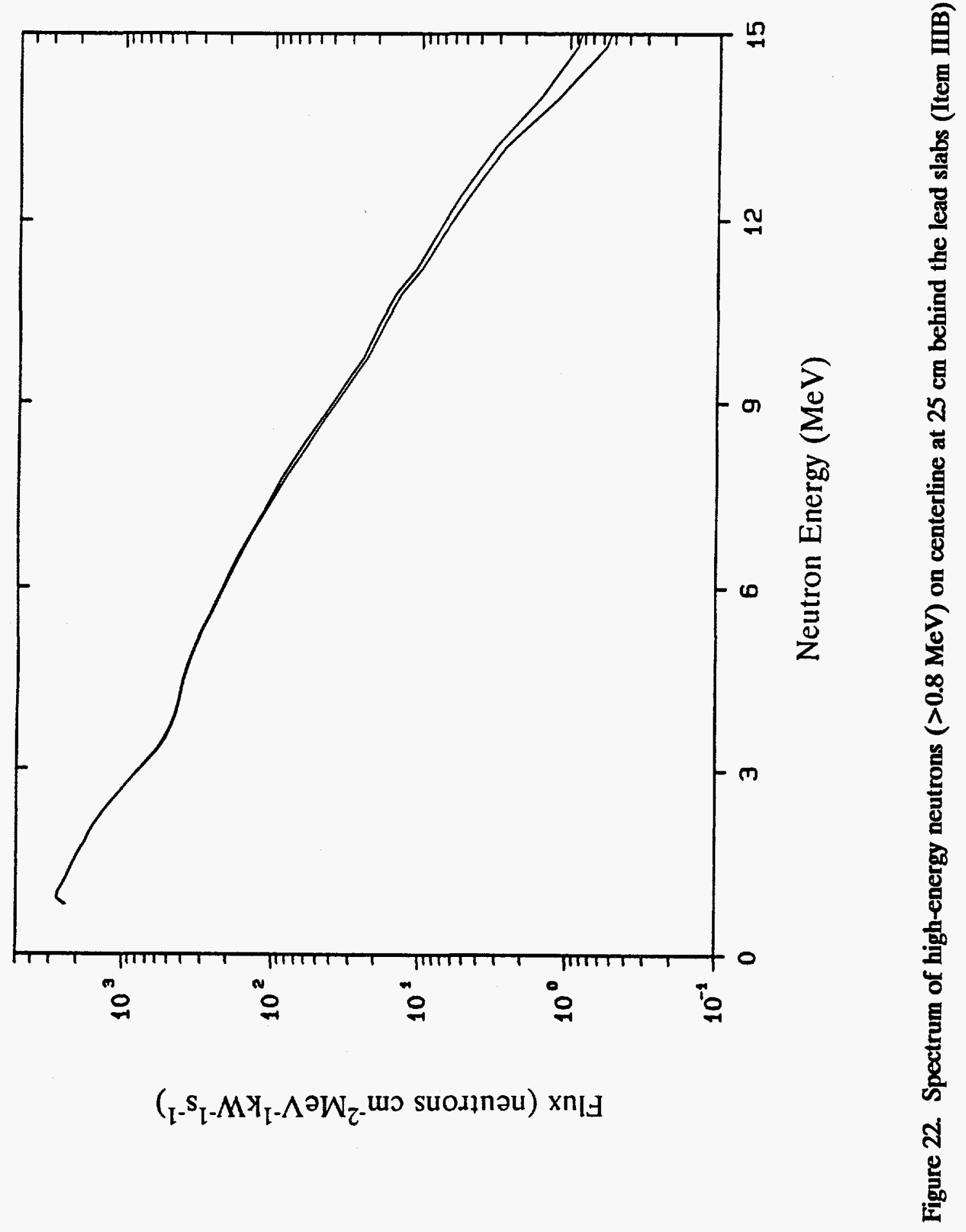




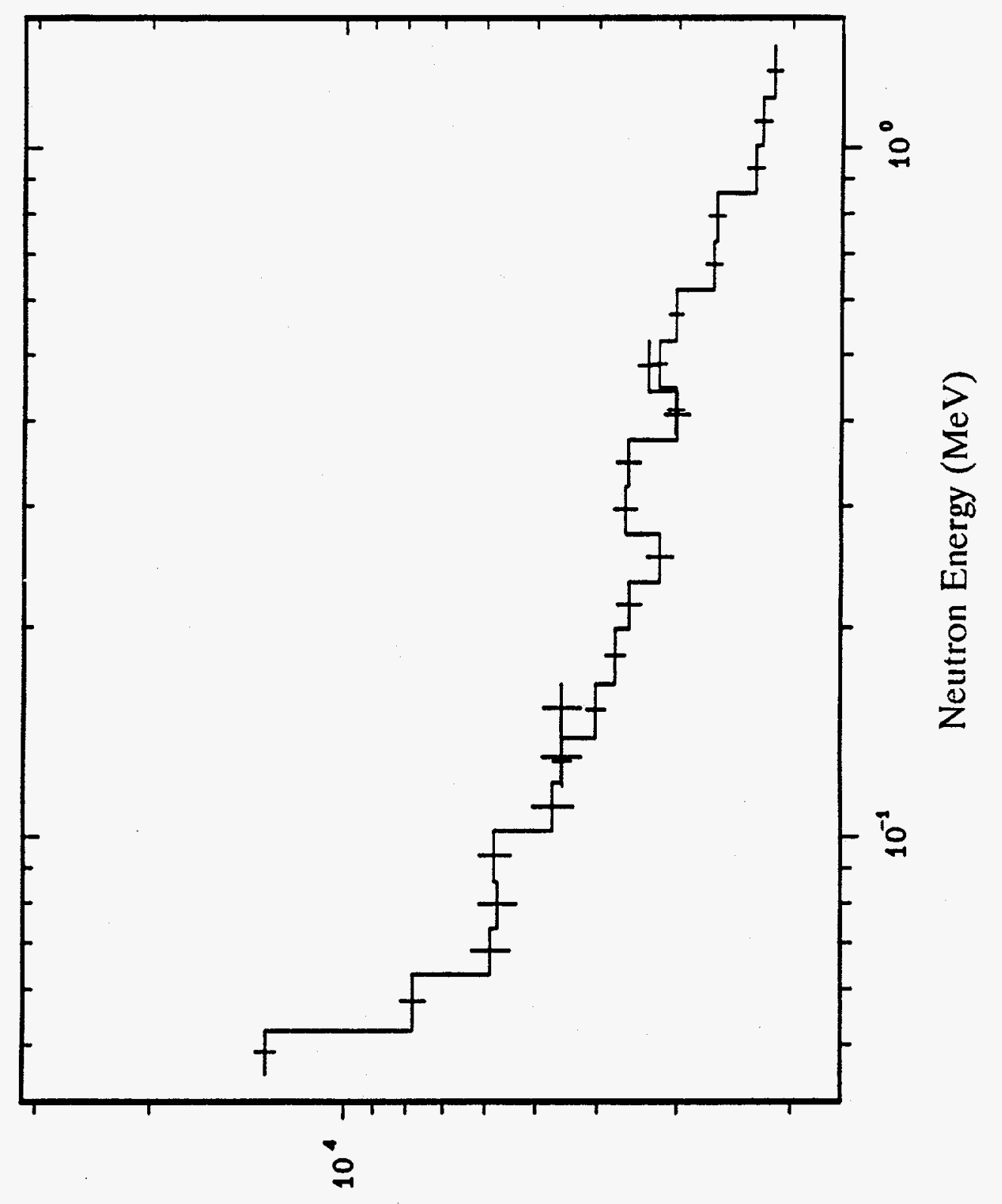

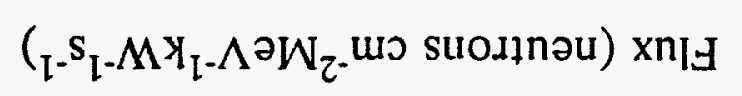

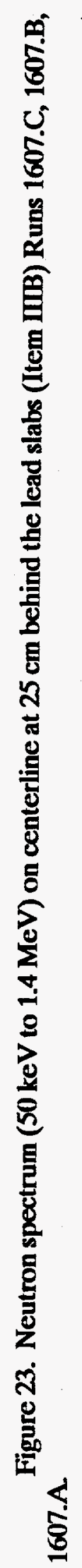




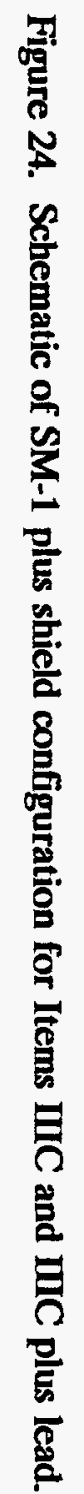

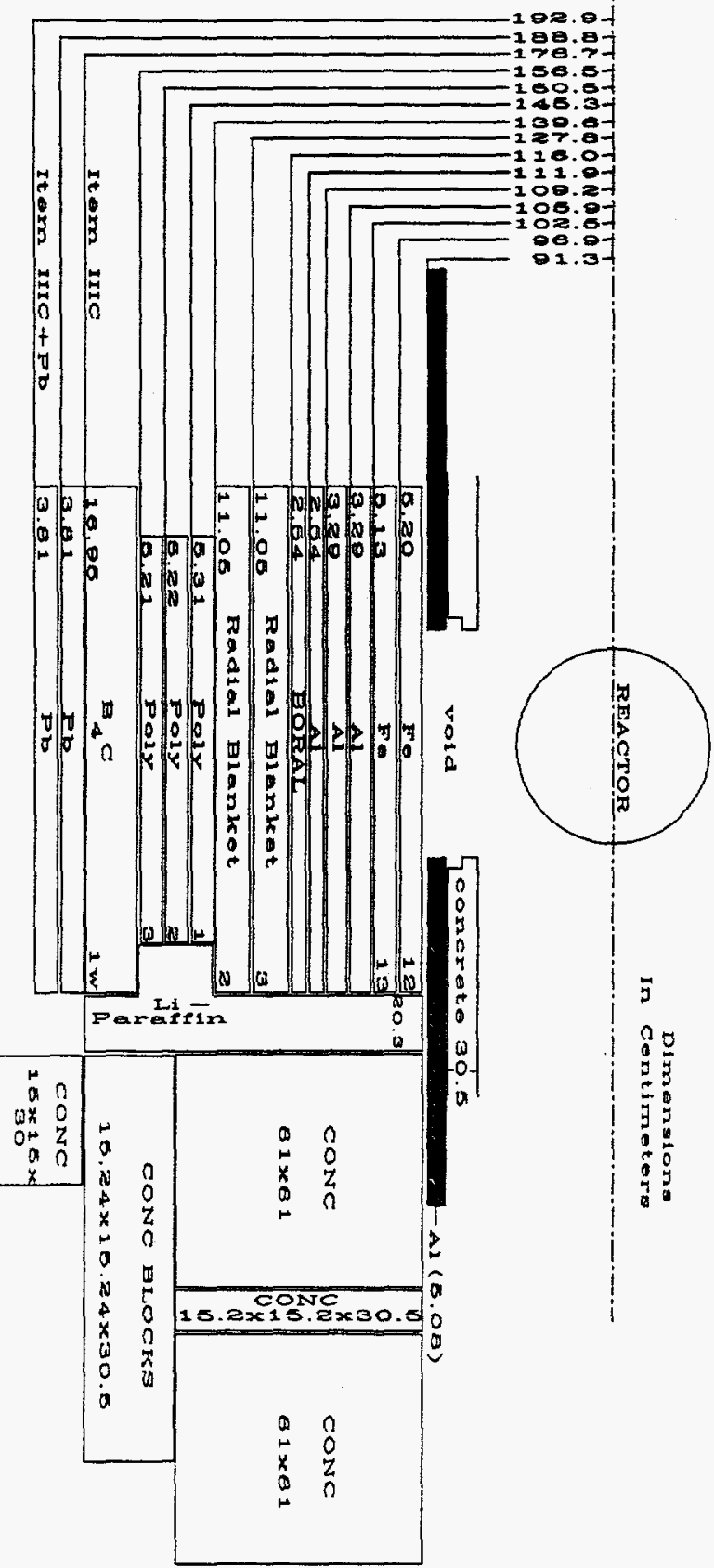




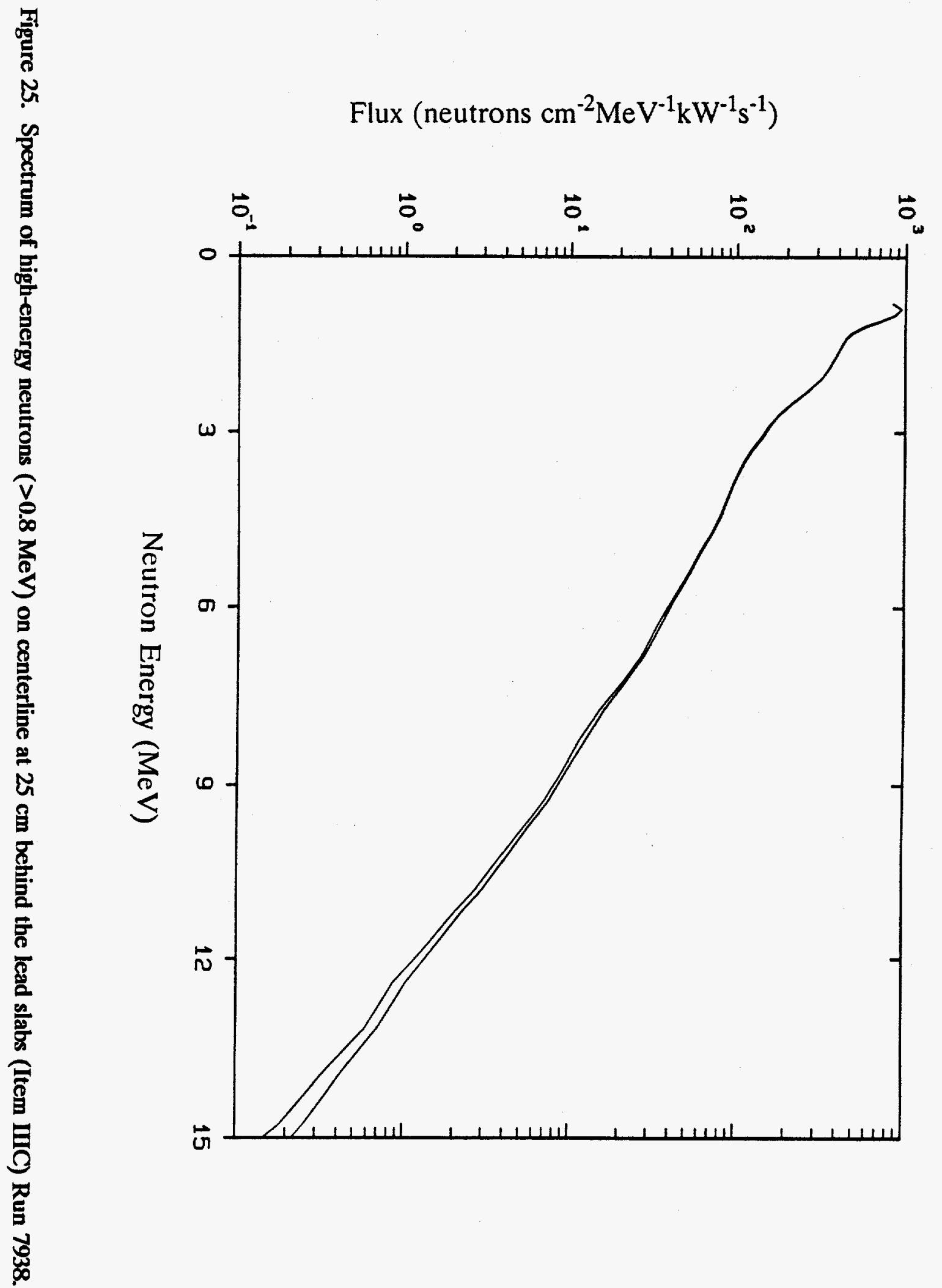




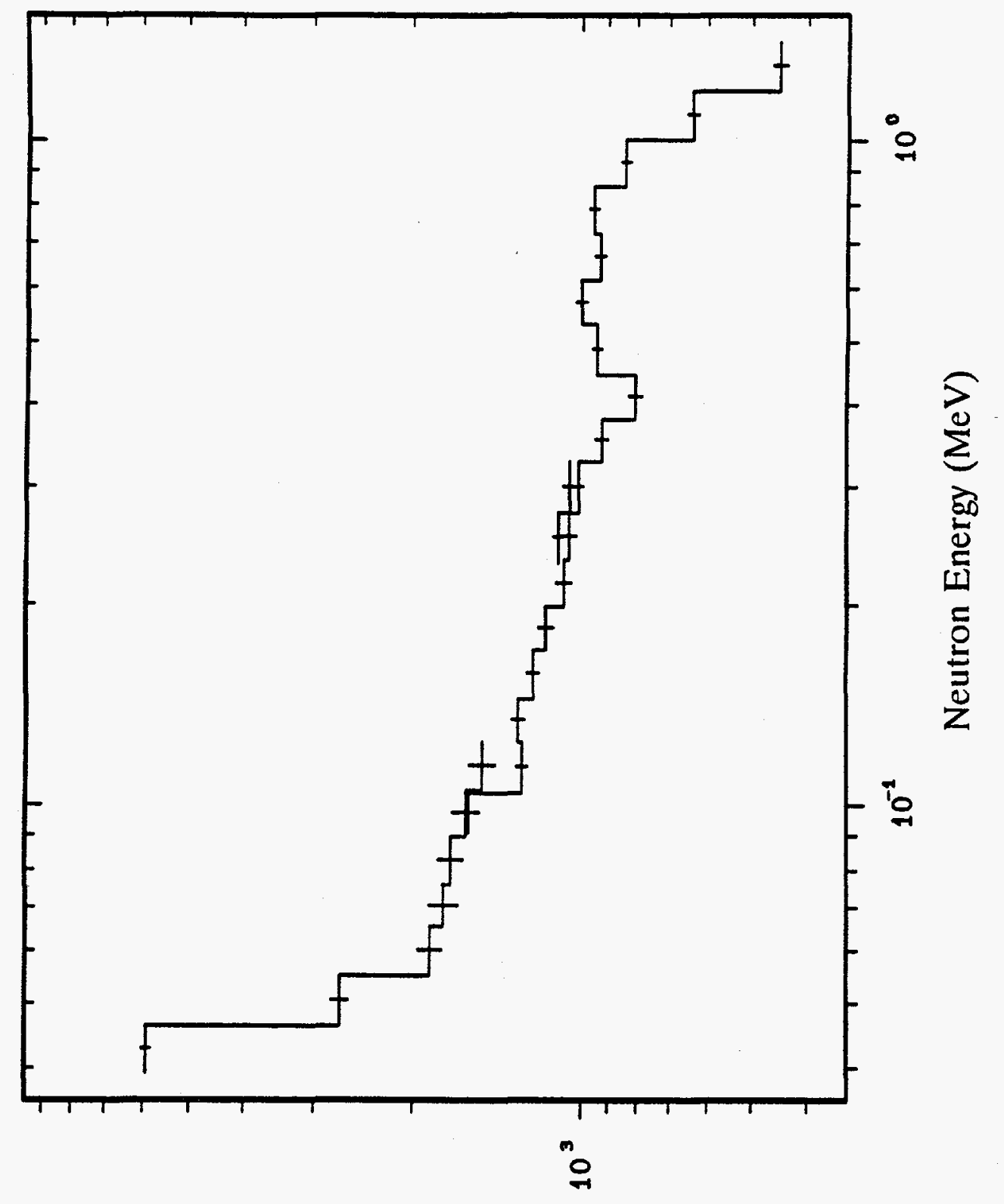

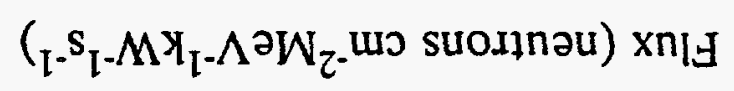




\section{DISTRIBUTION}

1. B. R. Appleton

2. J. A. Bucholz

3. L. B. Holland

4. F. J. Homan

5. H. T. Hunter

6-15. D. T. Ingersoll

16-17. F. J. Muckenthaler

18. J. V. Pace, III

19. J. A. Ray

20. C. O. Slater
21. R. R. Spencer

22. R. C. Ward

23. J. D. White

24. A. Zucker

25. Central Research Library

26-30. EPMD Reports Office

31. ORNL Y-12 Technical Library

Document Reference Section

32-34. Laboratory Records

35. ORNL Patent Office

\section{EXTERNAL DISTRIBUTION}

36. Office of Assistant Manager for Energy Research and Development, DOE-OR, P.O. Box 2008, Oak Ridge, TN 37831-6269.

37. L. F. Blankner, Energy Research and Development, DOE-OR, P.O. Box 2008, Oak Ridge, TN 37831-6269.

38. Prof. Roger W. Brockett, Harvard University, Pierce Hall, 29 Oxford Street, Cambridge, Massachusetts 02138.

39. L. L. Carter, Westinghouse-Hanford Company, 400 Area Trailer 1, P.O. Box 1970, Richland WA 99352.

40. R. K. Disney, Westinghouse Electric Company, P.O. Box 158, Madison, PA 15663.

41. Prof. John J. Dorning, Department of Nuclear Engineering and Engineering Physics Reactor Facility, University of Virginia, Charlottesville, VA 22903.

42. P. B. Hemmig, Safety and Physics Branch, Office of Technology Support Programs, DOE-Washington, Washington, DC 20585.

43. Dr. James E. Leiss, Route 2, Box 142C, Broadway, VA 22815.

44. Prof. Neville Moray, Department of Mechanical and Industrial Engineering, 1206 West Green Street, Urbana, IL 61801. 
45. Prof. Mary F. Wheeler, Department of Mathematical Sciences, Rice University, P.O. Box 1892, Houston, TX 77251.

46. K. Itoh, Power Reactor and Nuclear Fuel Development Corporation, Sankaido Building, 9-13, 1-Chome, Akasaka, Minato-Ku, Tokyo 107, Japan.

47. A. Shono, Oarai Engineering Center, Power Reactor and Nuclear Fuel Development Corporation, 4002, Marita, Oarai-Machi, Higashi-Kbaraki-Gun, Ibaraki-Ken, 311-13, Japan.

48. M. Tsutsumi, Power Reactor and Nuclear Fuel Development CorporationWashington, Suite 715, 2600 Virginia Avenue NW, Washington, DC 20037.

49. K. Chatani, Power Reactor and Nuclear Fuel Development Corporation, 4002 Narita-Cho, O-Arai-Machi, Ibaraki-Ken, 311-13, Japan.

50-122. Given distribution as shown in DOE/OSTI-4500-R75, LMFBR-Physics: 